\title{
AVALIAÇÃO DO DESGASTE E DA RUGOSIDADE SUPERFICIAL DE UMA RESINA COMPOSTA, APÓS ESCOVAÇÃO SIMULADA, EM FUNÇÃO DE DIFERENTES ENERGIAS E FONTES DE LUZ USADAS NA POLIMERIZAÇÃO.
}

MIGUEL ALBERTO DE JESÚS ASENJO MARTÍNEZ

Dissertação apresentada à Faculdade de Odontologia de Bauru, da Universidade de São Paulo, como parte dos requisitos para obtenção do título de Mestre em Odontologia, área Dentística. 


\section{AVALIAÇÃO DO DESGASTE E DA RUGOSIDADE SUPERFICIAL DE UMA RESINA COMPOSTA, APÓS ESCOVAÇÃO SIMULADA, EM FUNÇÃO DE DIFERENTES ENERGIAS E FONTES DE LUZ USADAS NA POLIMERIZAÇÃO.}

Dissertação apresentada à Faculdade de Odontologia de Bauru, da Universidade de São Paulo, como parte dos requisitos para obtenção do título de Mestre em Odontologia, área Dentística.

Orientador: Prof. Dr. Rafael Francisco Lia Mondelli

\section{BAURU}

2004 
Asenjo-Martínez, Miguel Alberto de Jesús

As27a Avaliação do desgaste e da rugosidade superficial de uma resina, após escovação simulada, em função de diferentes fontes de luz. / Miguel Alberto de Jesús Asenjo-Martínez. -- Bauru, 2004. xxiii 154p.: il. ; $30 \mathrm{~cm}$.

Dissertação (Mestrado) -- Faculdade de Odontologia de Bauru. Universidade de São Paulo.

Orientador: Prof. Dr. Rafael Francisco Lia Mondelli

Autorizo, exclusivamente para fins acadêmicos e científicos, a reprodução total ou parcial desta dissertação/tese, por processos fotocopiadores e outros meios eletrônicos.

Assinatura:

Data: 


\section{MIGUEL ALBERTO DE JESÚS ASENJO MARTINEZ}

\section{DADOS CURRICULARES}

22 de Fevereiro 1976

Santo Domingo,

República Dominicana.

Filiação

1993-1999

$1999-2001$

2001-2002

2003-2004

Associações
Nascimento

Luz Minerva Martínez

Miguel Alberto Asenjo Lugo

Graduação em Odontologia

Universidad Autónoma de Santo Domingo (UASD).

Professor Assistente do Instituto

Odontológico de Especialidades (IOES). Monitor do Departamento de Operatória Dental. Universidad Autónoma de Santo Domingo (UASD).

Curso de Especialização em Prótese Dentária. Faculdade de Odontologia da Universidade de Itaúna (FOI).

Curso de Pós Graduação em Dentística, nível mestrado - Faculdade de Odontologia de Bauru - USP.

AOD: Asociación Odontológica Dominicana SBPqO: Sociedade Brasileira de Pesquisa Odontológica 


\section{A essência de ser}

Eu sou o que sou

como uma árvore retorcida

que o tempo moldou

como penhasco escarpado

que água erodiu

eu sou o resultado de tudo o que você não viu

o que você vê agora são apenas as marcas

que ficaram pelo lado de fora

mais a seiva que dentro de mim corre

e água que brota de mim escorre são

as certezas que tenho de que sendo

o que sou a vida dentro de mim não morre.

Miguel Asenjo Martínez

Coleção Poesias e Vinhos 


\section{A Deus,}

Pai de todos nós, que em sua infinita bondade, me abençoou para alcançar e vencer mais uma etapa de vida. Agradeço ao Senhor por me fazer uma pessoa autêntica, corajosa e fiel aos meus princípios. Tua proteção e guia divina sempre serão fontes inesgotáveis de inspiração, luta e vitória. 


\section{Dedicatória}

A minha amada mãe Profa Luz Minerva Martínez,

Por ser a principal motivadora de meu caminho docente e ser um perfeito exemplo de disciplina, retidão, integridade, legitimidade, organização, empreendimento e trabalho. Qualidades que sempre foram misturadas com comunicação, ternura, compreensão, respeito e amor. Mãe não é somente aquela que gera, concebe, carrega em seu seio e dá à luz a uma criança, mais sim uma pessoa que cuida de que seu filho seja um diamante com brilho próprio. Muito obrigado, ser amado, por me ensinar a ser águia e não galinha.Você é e sempre será o estímulo de todas minhas conquistas. É uma honra ser teu filho, mãe de minha alma!

\section{A meu mar Andréa Manente Lazeris e família,}

Por acreditar em minha integridade humana, por escolher sonhar os meus sonhos, por decidir trilhar junto o caminho que decidimos e, sobretudo, por ser meu eterno amor. Nunca esqueça que ter um ideal é saber lutar para alcançá-lo. Construir é nossa ferramenta chave. Lembre-se, somos impossíveis de tão possíveis que somos...!

\section{A meu pai Miguel Asenjo Lugo e irmãos Danilo Alberto e Ariasmy Milagros,}

Este é o resultado de toda a paciência que vocês tiveram comigo. Peço perdão pela ausência como filho e irmão durante todo este tempo de dedicação profissional. Sempre é preciso pagar um preço. Espero que a finalização deste terceiro trabalho (tesegraduação, monografia-especialização e tese-mestrado) seja motivo de orgulho e satisfação para todos vocês que sempre sentiram minha falta. 


\section{Agradecimentos Especiais}

Ao meu orientador Prof. Dr. Rafael Francisco Lia Mondelli,

Pelo incentivo e confiança que sempre me dedicou nestes anos de convivência. Por confiar em minha capacidade e, principalmente, pelo amigo que se mostrou nos momentos mais difíceis de minha vida universitária. Rafael, experimento extrema felicidade por ser seu orientado. Ser-lhe-ei eternamente grato pela disponibilidade irrestrita em atender minhas solicitações de ajuda, colaborando de forma decisiva para a conclusão desse trabalho. Muito obrigado pelo apoio incondicional e por me permitir fazer parte de seu núcleo familiar. Este trabalho é seu.

Ao Prof. Dr. Eduardo Batista Franco,

Pela paciência, educação e humildade com que compartilhou seus conhecimentos, experiências e orientações neste trabalho e com minha pessoa. Sua postura de verdadeiro e consagrado educador sempre serão um excelente referencial durante toda minha vida.

Ao Prof. Dr. José Mondelli,

Por acreditar em minhas habilidades clínicas, por suas fortes criticas e sábios conselhos, pela experiência transmitida e, especialmente, por mostrar-me o significado de ser um verdadeiro professor. "O saber a gente aprende com os mestres e com os livros. A sabedoria se aprende é com a vida e com os humildes". Cora Coralina. Minha eterna gratidão. 
Aos meus amigos, colegas e professores Heitor, Daniela, Renato e Anuradha,

Estas linhas são poucas para agradecer sinceramente a colaboração de vocês neste trabalho. Espero sempre louvar este ato nobre de carinho, amizade e solidariedade. Obrigado pelas informações transmitidas e pela gentileza de tornar minha vida Bauruense muito mais prazerosa. Podem contar comigo sempre.

\section{Ao Prof Dr. Euloir Passanezi,}

Pela confiança, apoio e indicação no mestrado, que hoje por meio deste trabalho chega a sua etapa final. Sua conduta docente e exemplo humano sempre serão firmes suportes em minha vida. Muito obrigado. Fiz o que o senhor um dia me falou: Miguel faça o que se faz em Bauru, PRODUZIR. Missão cumprida.

Ao amigo e irmão Prof. Dr. Domingo Santos Pantaleón,

Por, felizmente, contaminar-me deste estilo de vida incompreendido por muitos e invejados por outros. Ao final o tempo será o verdadeiro juiz desta revolução. Saiba que a conquista deste degrau também faz parte de nossa história, planos e amizade. Nos, agradecidos, sempre falaremos da luz......!

Aos Professores Doutores Carlos Eduardo Francischone e José Carlos Pereira,

Por ser manancial de conhecimento e me demonstrar que a melhor forma de ensinar é estudar permanentemente. Sempre admirarei vossas capacidades e habilidades clínicas. Muito obrigado pelas críticas e sugestões. 


\section{Agradecimentos}

Esta página é destinada especialmente a todos aqueles que, ao longo destes quatro anos, fizeram de minha vida uma rica fonte de esperança, amor, integridade e fé. Agradeço a Deus por todos vocês existirem. Todo meu amor e afeto para meus tios, amigos e familiares, em especial para: Carlos y Elizabeth Lugo, Manuel $\mathcal{N}$ ñnez, Margarita Ferreira, Mercedes Clarck, Teodoro de Jesús Cruz Vargas, Laura Féliz, Mercedes Sepúlveda, Robinson Rodríguez, Gisell Amarante, Nelson Aquino, Justo Reyes, Desiré Sánchez, Tio Pancho, Fátima Asenjo, Danilo Nuñez, Dom Mário Echavalier, Raquel Delgado, Dona Meiry Guimarães, Frederico Marques, Nivaldo Carvalho e Eduardo Lemos de Souza. Obrigado pelo apoio e me mostrar que é caminhando que se faz o caminho.

A todos os meus queridos colegas de Pós-graduação (Mestrado e Doutorado/2003), pelas doçuras e amarguras compartidas e divididas durante o mestrado. Aos funcionários do departamento de Dentística e Pós-graduação pela atenção e cuidados dispensados.

Agradeço infinitamente a pureza, as horas de convivência e a verdadeira amizade do meu irmão catarinense Eduardo Bortoluzzi (Duda Camacho). Conte comigo irmão.

Aos professores de Materiais Dentários, e em especial para o Prof. César, pelo amor demonstrado nas aulas de desgaste e perfilômetria, ao Paulinho por ser meu pai brasileiro, ao Prof Paulo Amarante pelo seu exemplo de educação e cultura. Aos funcionários Sandrinha e o Pajaro Alcides pelo carinho e acolhida.

Aos conterrâneos e amigos Tania Rodríguez, Belķis de la Gruz e especialmente ao caçula Gregory Sócias, por acreditar na amizade, pelo humor manifestado e entender que cada dia é uma nova oportunidade para transformarmos em melhores seres humanos.

\section{Este trabalho é de todos vocês.}




\section{Agradecimentos Institucionais}

Ao colégio Dom Bosco que por meio de seus fortes princípios salesianos me deram uma formação humanística, religiosa e acadêmica inquebrantáveis para toda minha vida. Em homenagem póstuma ao sacerdote, professor, educador, amigo e cientista cubano, P.Victor Miranda por exigir de mim a perfeição e me mostrar que a melhor revolução é lutar contra a mediocridade buscando sempre um ideal, a vitória. Te amo, iluminado comandante e chefe.

À Universidad Autónoma de Santo Domingo (UASD) pela oportunidade de me formar como Cirurgião Dentista.

Ao Instituto Odontológico de Especialidades (IOES), pela possibilidade de transformar todas minhas dúvidas profissionais em sólidas certezas.

À Secretaria de Estado de Saúde Pública e Assistência Social (SESPAS) pelo apoio financeiro durante meus estudos. Obrigado pela confiança em mim depositada. Espero retribuir com fatos seus investimentos.

À faculdade de Odontologia da Universidade de Itaúna pela formação clínica e cientifica obtida durante o curso de especialização.

À Faculdade de Odontologia de Bauru, Universidade de São Paulo, por ser semente fértil de minha formação profissional, humana e docente. Levarei seu nome e experiências sempre comigo.

\section{Obrigado por escalar junto esta montanha.}




\section{SUMÁRIO}

Lista de abreviaturas e símbolos........................................................ xiii

Lista de figuras.............................................................................

Lista de tabelas......................................................................... xxi

Lista de Anexos.............................................................................. $\quad$ xxii

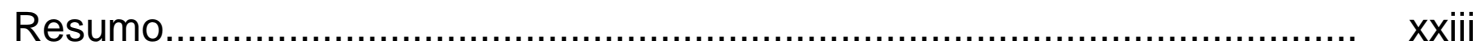

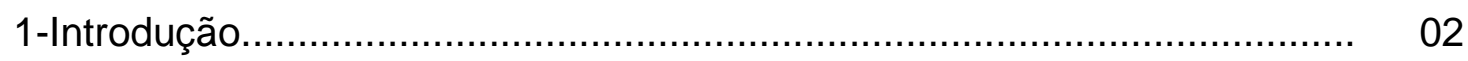

2-Revisão da Literatura.......................................................................... 11

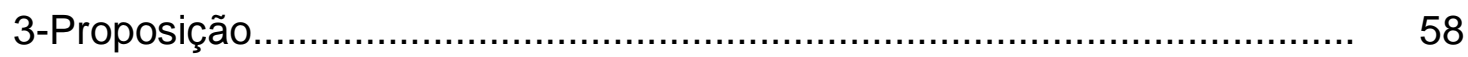

$4-$ Material e métodos............................................................... 60

5-Resultados.......................................................................... 85

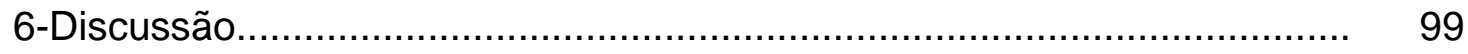

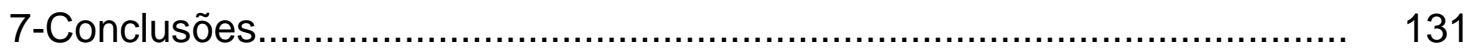

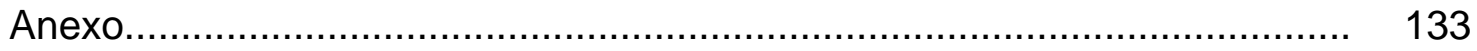

Referências bibliográficas............................................................... 136

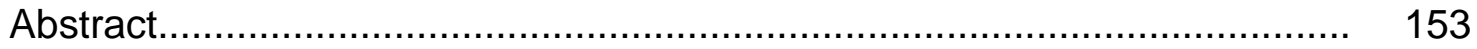




\section{LISTA DE ABREVIATURAS, SIGLAS E SÍMBOLOS}

\%: Porcentagem

$\mu \mathrm{m}$ : Micrometro

\pm : Mais ou menos

ADA: American Dental Association

Bis-GMA: Bisfenol glicidil metacrilato

Ca: Cálcio

$\mathrm{CaCO}_{3}$ : carbonato de Cálcio

cm: Centímetro

$\mathrm{cm}^{2}$ : Centímetro quadrado

CQ: Canforoquinona

DMPT: Demetil-para-toluidina

DP: Desvio padrão

FTIR: Espectrometria no infravermelho com transformada de Fourier (Fourier Transform Infrared Spectrometer)

GC: Grau de conversão

g: Grama

H: Hora

Hz: Hertz

In situ (latim): em sítio, no local (no caso, cavidade bucal)

In vitro (latim): em laboratório

ISO: International Organization for Standardization

$\mathrm{J} / \mathrm{cm}^{2}$ : Joules por centímetro quadrado

Kg: Quilograma

LCU: Light-curing-unit

LED: Light-emitting-diode

LH: Luz halógena

mm: Milímetro 
$\mathrm{mm}^{2}$ : Milímetro ao quadrado

$\mathrm{ml}$ : Mililitro

$\mathrm{mW}$ : Miliwatts

$\mathrm{mW} / \mathrm{cm}^{2}$ : Miliwatts por centímetro quadrado

MEV: Microscopia eletrônica de varredura

MFP: Máximo Flúor Protetor

Mpa: Mega Pascal

$\mathrm{nm}$ : Nanometro

\#: number (número na língua inglesa)

$\mathrm{N}$ : Unidade química $=$ Normal

${ }^{\circ} \mathrm{C}$ : Graus Celsius

p: Probabilidade

$\mathrm{pH}$ : Potencial hidrogeniônico

$\mathrm{P}^{32}$ : Isótopo de fósforo

$\mathrm{PO}_{4}$ : Fosfato

ppm: parte por milhão

PVC: Cloreto de polivinil

PPD: Fenil-propanodiona

Q.A.:Quimicamente ativada

$\mathrm{RL}$ : Radicais livres

Ra: Rugosidade aritmética

Rmax: Rugosidade máxima

$\mathrm{RI}$ : Rugosidade inicial

RF: Rugosidade final

r.p.m.: Rotações por minuto

s: Segundo

$\mathrm{SiO}_{2}$ : Sílica

TMPT: Trimetilol propano trimetacrilato

TEGDMA: trietilenoglicol de dimetacrilato 
UDMA: Uretano dimetacrilato

$\mathrm{X}$ : Indica o número de vezes 


\section{LISTA DE FIGURAS}

FIGURA 1 Apresentação comercial da resina composta Filtek $^{\mathrm{TM}}$ Z-250 (3M/ESPE)

FIGURA 2 Apresentação comercial da fonte de luz tipo halógena VIP (Bisco, inc. USA).

FIGURA 3 Apresentação comercial da fonte de luz tipo LED Ultrablue IS (DMC Equipamentos).

FIGURA 4 Apresentação comercial do dentifrício e escova dental empregado

FIGURA 5 Projeto gráfico e medidas da cavidade, braços e plataforma da matriz empregada.

FIGURA 6 Matriz de aço inoxidável.

FIGURA 7 Esquema ilustrativo da aplicação dos incrementos para obtenção final dos corpos-de-prova......

FIGURA 8 Politriz Metalográfica.

FIGURA 9 Rugosímetro Hommel Tester T 1000 
FIGURA 10 Ponta apalpadora do Rugosímetro Hommel T100.

FIGURA 11 Máquina utilizada nos testes de escovação simulada

FIGURA 12 Disposição do espécime na barra metálica do equipamento.

FIGURA 13 Proteção e disposição do espécime em relação à escova dental

FIGURA 14 Escovação do espécime.

FIGURA 15 Escovação simultânea dos espécimes.

FIGURA 16 Ilustração esquemática mostrando o desgaste dos espécimes testados.

FIGURA 17 Perfil real de desgaste do G1 $\left(\mathrm{LH}=300 \mathrm{~mW} / \mathrm{cm}^{2} \times 20 \mathrm{~s}\right)$.

FIGURA 18 Perfil real de desgaste do G2 (LH = $\left.600 \mathrm{~mW} / \mathrm{cm}^{2} \times 20 \mathrm{~s}\right)$.

FIGURA 19 Perfil real de desgaste do G3 (LED $\left.=300 \mathrm{~mW} / \mathrm{cm}^{2} \times 20 \mathrm{~s}\right)$.........

FIGURA 20 Perfil real do G4 (LED $\left.=600 \mathrm{~mW} / \mathrm{cm}^{2} \times 20 \mathrm{~s}\right)$. 
FIGURA 21 Gráfico representativo dos valores médios de desgaste $(\mu \mathrm{m})$ dos diferentes grupos avaliados.

FIGURA 22 Perfil de rugosidade superficial do corpo-de-prova em resina composta antes do procedimento de abrasão (lado controle)

FIGURA 23 Perfil de rugosidade superficial do corpo-de-prova em resina composta após o procedimento de abrasão (lado escovado).

FIGURA 24 Gráfico das diferenças entre os valores das rugosidades superficiais $(\mu \mathrm{m})$ antes e após o teste de escovação simulada

FIGURA 25 Gráfico de variação da rugosidade superficial $(\mu \mathrm{m})$ dos grupos testados após a escovação.

FIGURA 26 Exemplo de uma fotomicrografia com 45x de aumento da resina composta testada antes (lado controle) e após (lado escovado) a escovação simulada.

FIGURA 27 Exemplo de uma fotomicrografia com 150x de aumento da resina composta testada antes (lado controle) e após (lado escovado) a escovação simulada.

FIGURA 28 Fotomicrografia com 1500x de aumento da superfície de resina composta do G1 $\left(\mathrm{LH}=300 \mathrm{~mW} / \mathrm{cm}^{2} \times 20 \mathrm{~s}\right)$ antes (lado controle) da escovação simulada 
FIGURA 29 Fotomicrografia com 1500x de aumento da superfície de resina composta do G1 (LH = 300mW/cm ${ }^{2} \times 20 s$ ) após (lado escovado) a escovação simulada.

FIGURA 30 Fotomicrografia com 1500x de aumento da superfície de resina composta do G2 $\left(\mathrm{LH}=600 \mathrm{~mW} / \mathrm{cm}^{2} \times 20 \mathrm{~s}\right.$ ) antes (lado controle) da escovação simulada.

FIGURA 31 Fotomicrografia com 1500x de aumento da superfície de resina composta do G2 (LH $=600 \mathrm{~mW} / \mathrm{cm}^{2} \times 20 s$ ) após (lado escovado) a escovação simulada.

FIGURA 32 Fotomicrografia com 1500x de aumento da superfície de resina composta do G3 (LED $=300 \mathrm{~mW} / \mathrm{cm}^{2} \times 20 \mathrm{~s}$ ) antes (lado controle) da escovação simulada.

FIGURA 33 Fotomicrografia com 1500x de aumento da superfície de resina composta do G3 (LED $=300 \mathrm{~mW} / \mathrm{cm}^{2} \times 20 \mathrm{~s}$ ) após (lado escovado) da escovação simulada.

FIGURA 34 Fotomicrografia com 1500x de aumento da superfície de resina composta do G4 (LED $=600 \mathrm{~mW} / \mathrm{cm}^{2} \times 20 \mathrm{~s}$ ) antes (lado controle) da escovação simulada

FIGURA 35 Fotomicrografia com 1500x de aumento da superfície de resina composta do G4 (LED $=300 \mathrm{~mW} / \mathrm{cm}^{2} \times 20 \mathrm{~s}$ ) após (lado escovado) a escovação simulada. 
FIGURA 36 Representação esquemática das dimensões exatas (em mm) da cabeça e posicionamento dos tufos da escova dental sobre o corpo-de-prova............. 105

FIGURA 37 Ilustração esquemática mostrando a direção de leitura feita pela ponta apalpadora do Rugosímetro para a quantificação do desgaste.

FIGURA 38 Ilustração esquemática do processo de filtragem automática realizada pelo Rugosímetro em qualquer tipo de superfície 


\section{LISTA DE TABELAS}

TABELA 1 Apresentação da característica, sistema de ativação, fabricante, número de lote, ano e mês de validade da resina composta utilizada neste estudo.

TABELA 2 Composição básica da resina composta empregada..

TABELA 3 Características de regulagem da densidade de potência dos aparelhos fotopolimerizadores.

TABELA 4 Distribuição dos grupos testados

TABELA 5 Composição do dentifrício Colgate MFP......

TABELA 6 Média do desgaste $(\mu \mathrm{m})$, desvio padrão e análise estatística dos diferentes grupos estudados.

TABELA 7 Valores das médias de rugosidades $(\mu \mathrm{m})$ iniciais, finais, desvio padrão, diferenças e análise estatística dos grupos estudados.... 


\section{ㄴISTA DE ANEXOS}

ANEXO 1 Médias dos valores $(\mu \mathrm{m})$ de rugosidade superficial e desgaste registrados de cada corpo-de-prova do $\mathrm{G} 1\left(\mathrm{LH}=300 \mathrm{~mW} / \mathrm{cm}^{2} \mathrm{x}\right.$ 20s) e as diferenças obtidas após os testes de escovação simulada.

ANEXO 2 Médias dos valores $(\mu \mathrm{m})$ de rugosidade superficial e desgaste registrados de cada corpo-de-prova do $\mathrm{G} 2\left(\mathrm{LH}=600 \mathrm{~mW} / \mathrm{cm}^{2} \mathrm{x}\right.$ 20s) e as diferenças obtidas após os testes de escovação simulada.

ANEXO 3 Médias dos valores $(\mu \mathrm{m})$ de rugosidade superficial e desgaste registrados de cada corpo-de-prova do G3 (LED $=300 \mathrm{~mW} / \mathrm{cm}^{2} \mathrm{x}$ 20s) e as diferenças obtidas após os testes de escovação simulada

ANEXO 4 Médias dos valores $(\mu \mathrm{m})$ de rugosidade superficial e desgaste registrados de cada corpo-de-prova do G4 (LED $=600 \mathrm{~mW} / \mathrm{cm}^{2} \mathrm{x}$ 20s) e as diferenças obtidas após os testes de escovação simulada. 
RESUMO 


\section{RESUMO}

Avaliou-se in vitro o desgaste e a rugosidade superficial da resina composta Filtek $^{\text {TM }}$ Z-250 (3M/ESPE), após escovação simulada, em função de diferentes energias e fontes de luz usadas na polimerização. Foram utilizadas duas fontes de luz: halógena (VIP/BISCO) e LED (Ultrablue IS / DMC equipamentos). Uma matriz de aço inoxidável foi empregada na obtenção de quarenta corpos-de-prova (15X5mm) divididos em 4 grupos: G1: VIP $300 \mathrm{~mW} / \mathrm{cm}^{2} \times 20 \mathrm{~s} ; \mathrm{G} 2=\mathrm{VIP}$ $600 \mathrm{~mW} / \mathrm{cm}^{2} \times 20 \mathrm{~s} ; \mathrm{G} 3:$ LED $300 \mathrm{~mW} / \mathrm{cm}^{2} \times 20 \mathrm{~s}$ e G4: LED $600 \mathrm{~mW} / \mathrm{cm}^{2} \times 20 \mathrm{~s}$. A metade de cada corpo-de-prova foi protegida e a outra metade submetida a 200.000 ciclos de escovação, utilizando-se escovas dentais (Kolynos) e pasta dental (Colgate), diluída em água deionizada. O desgaste foi determinado após a realização de 5 leituras para cada espécime. O rugosímetro foi utilizado para verificar as diferenças entre o perfil real entre as duas superfícies. A alteração da rugosidade superficial $(\mathrm{Ra})$ foi determinada pela diferença entre a média de cinco leituras iniciais (antes da escovação) e de cinco finais (após escovação). Os resultados foram submetidos à análise de variância a dois critérios e teste de Tukey $(p<0,05)$. O desgaste apresentado foi: $G 1: 13,96 \pm 0,756 \mu m$ (B); $G 2$; $10,90 \pm 0,507 \mu \mathrm{m}$ (A); G3: $34,63 \pm 1,931 \mu \mathrm{m}$ (C) e $\mathrm{G} 4 ; 12,95 \pm 0,510 \mu \mathrm{m}$ (B). As

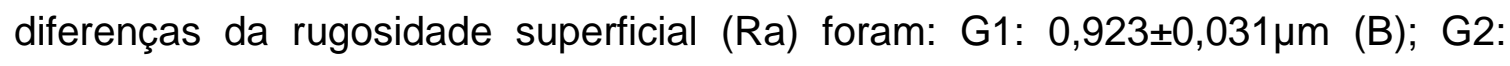
$0,891 \pm 0,036 \mu \mathrm{m}(\mathrm{A}) ; \mathrm{G} 3: 1,031 \pm 0,019 \mu \mathrm{m}$ (C) and G4: 0,918 $\pm 0,032 \mu \mathrm{m}(\mathrm{B})$. De forma geral, a fonte de luz halógena proporcionou melhor comportamento físicomecânico da resina composta avaliada em comparação a fonte de luz LED com mesma energia de ativação. 


\section{INTRODUÇÃO}




\section{INTRODUCÃO}

A Odontologia atual está inserida em um contexto que promove, seja por procedimentos diretos ou indiretos, a otimização da estética. O conceito de estética remete ao conjunto de princípios em conformidade com determinado ideal de beleza. Conseqüentemente, pode-se considerar as resinas compostas como material de eleição para os procedimentos restauradores cuja finalidade é a manutenção harmônica do sorriso ${ }^{78}$.

A opção pelas resinas como alternativa de tratamento restaurador estético de inserção direta ocorreu no início dos anos sessenta, como resultado de inúmeras tentativas de se obter um material que fosse superior aos existentes na época, as resinas acrílicas restauradoras e o cimento de silicato $^{99}$. Com o cimento de silicato, as restaurações estéticas diretas eram apenas direcionadas às restaurações de dentes anteriores. A partir da introdução da resina composta por BOWEN ${ }^{14}$, à base de bisfenol A-glicidilmetacrilato (Bis-GMA), este material tornou-se o "ddiamante almejável” da odontologia. Além do fator estético proporcionado, a associação das resinas compostas ao condicionamento ácido e ao sistema adesivo ${ }^{21}$ resultou em restaurações com adequada retenção e selamento marginal ${ }^{78}$. A maior incorporação de carga, melhor distribuição das partículas e introdução de iniciadores fotopolimerizáveis permitiu o aumento na indicação e qualidade das restaurações de compósitos por promover melhores propriedades do material. 
Nos últimos anos, o desenvolvimento dos componentes orgânicos e inorgânicos dos compósitos possibilitou o surgimento de grande variedade de resinas compostas, com indicações mais específicas ${ }^{62,63,106}$. Em virtude desta evolução, esses materiais começaram a ser indicados e utilizados na região posterior, onde os esforços sobre as restaurações são maiores ${ }^{78}$.

A princípio, as resinas compostas apresentavam-se em um sistema de duas pastas, com ativação química, proporcionando uma técnica menos sensível e mais econômica, por não ser necessária à utilização de aparelhos ativadores na polimerização. Sua polimerização, nesse sistema, é uniforme por meio da massa de material, já que a reação química ocorre quando as pastas, uma contendo o iniciador e outra o ativador, são misturadas ${ }^{5,15,22,25,84,93}$. A aceitação dessas resinas no mercado odontológico instigou a realização de pesquisas que levaram à elaboração das resinas ativadas por luz, conhecidas como fotoativadas, que são usadas largamente nos dias atuais. As resinas fotoativadas podem ter sistemas iniciados por luz visível ou ultravioleta, esta última praticamente removida do mercado por oferecer menor profundidade de polimerização e ser considerada nociva à saúde do cirurgião-dentista ${ }^{96}$.

Nas resinas compostas fotopolimerizáveis por luz visível, o processo de polimerização inicia-se com a absorção de luz pela molécula do fotoiniciador. Este fotoiniciador, na maioria das vezes, é a canforoquinona (CQ), que ao absorver energia luminosa com determinados comprimentos de onda (em $\mathrm{nm}$ ) passa para um estado excitado, denominado estado tripleto ${ }^{4,7,36,78,99}$. A 
combinação da $\mathrm{CQ}$ com a molécula intermediária, a amina terciária, leva à formação de radicais livres $(R L)$, dando início ao processo de polimerização. Daí em diante o processo continua de maneira semelhante aos sistemas de duas pastas. A luz que interage com o fotoiniciador funciona como fonte de energia necessária para promover a excitação da molécula, bem como para a formação de ligações químicas entre monômeros resinosos durante o processo de cura. A energia total fornecida para que determinada resina composta polimerize é o produto da intensidade de luz emitida pelo aparelho fotopolimerizador (em $\mathrm{mW} / \mathrm{cm}^{2}$ ) pelo tempo de exposição à luz (em segundos) $)^{20,36,37,49,65}$.

Deve-se ressaltar que as propriedades das resinas compostas fotoativadas dependem tanto de sua composição como de todo o processo empregado na sua polimerização. Desta forma, os principais fatores responsáveis pelo sucesso das restaurações estéticas realizadas em resina composta são: energia suficiente (densidade de potência) do aparelho, correto comprimento de onda emitido e tempo de exposição adequado ${ }^{38,50,59,79}$. No entanto, a energia luminosa emitida pela fonte deve pertencer à faixa do espectro de luz (em $\mathrm{nm}$ ) capaz de sensibilizar o fotoiniciador da resina composta $^{75}$. Assim, a qualidade e o bom funcionamento do aparelho fotopolimerizador são diretamente responsáveis pela qualidade do polímero formado no processo de polimerização $4,36,74,91,92,94$. 
A luz halógena convencional de quartzo-tungstênio $(\mathrm{LH})$ é, sem dúvida alguma, a fonte de luz visível mais popular aos profissionais da área odontológica. Mas apresenta algumas desvantagens que limitam sua vida útil ${ }^{36}$. Em conseqüência da alta temperatura em que as lâmpadas operam, ocorrem danos no bulbo, no refletor e no filtro, alterando a qualidade da luz emitida, afetando o grau de polimerização do material, sem que o profissional possa perceber $^{38,49,65}$, Além disso, tem-se demonstrado que muitos aparelhos que emitem LH não alcançam a mínima intensidade de luz especificada pelos fabricantes, devido à falta de manutenção e a não checagem da intensidade de luz do mesmo, ou ainda pelo fato do filtro e/ou lâmpada não serem substituídos regularmente ${ }^{4}$

Uma nova e promissora tecnologia que surgiu no mercado como opção para polimerizar materiais fotossensíveis sem os inconvenientes dos aparelhos de luz halógena é o LED (Light Emitting Diode) que são fontes de luz no estado sólido, compostos pela combinação de diferentes semicondutores para emissão de luz azul. Os aparelhos tipo LED não possuem filtros, uma vez que comprimentos de onda desnecessários não são gerados e, portanto, há mínima geração de calor. Ainda como vantagens deste aparelho, possui vida útil mais longa, de 10 mil $^{75}$ a 100 mil horas ${ }^{36}$, sem degradação significante do fluxo de luz com o passar do tempo além de serem altamente resistentes aos atos de ligar e desligar durante seu uso cotidiano ${ }^{5,7,13,100,103 .}$. 
A análise das propriedades mecânicas das resinas compostas é um importante fator para a indicação destes materiais nos diversos tipos de restaurações a serem empregados, principalmente quanto ao seu uso em dentes posteriores. Apesar das atribuições clinicamente estabelecidas pelas restaurações de amálgama, este material vem perdendo espaço para os materiais estéticos ${ }^{64,78,99}$. O apelo pela estética por parte dos pacientes fez com que muitos profissionais extrapolassem as indicações das resinas compostas em dentes posteriores, utilizando-as em situações limite.

Diante destas indicações e propriedades apresentadas pelo material, o principal problema enfrentado, apesar do aumento da resistência dos compósitos nos últimos anos, é o desgaste que se faz presente de forma rotineira $80,88,108$

O desgaste é definido por JONES; JONES; WILSON ${ }^{52}$, em 1972, como "perda progressiva de substância da superfície de um corpo provocado por uma ação mecânica". Este termo envolve diferentes processos encontrados na cavidade bucal, sendo de origens distintas: abrasão, atrição e erosão ${ }^{78}$. Nesse sentido, a abrasão seria um tipo de fator de desgaste, correspondendo a um processo em que o material é progressivamente removido da superfície de um sólido por ação de corte de um material abrasivo. Como tal, o material restaurador pode desgastar-se por abrasão como resultado da escovação ${ }^{1,44,45,90,102,112}$, contatos dentários ${ }^{86,60}$ e atrito da mastigação de elementos abrasivos ${ }^{28,52}$. 
O processo físico de escovação afeta a superfície das estruturas dentárias e de materiais restauradores presentes, além do periodonto circunjacente, independente da técnica de escovação utilizada ${ }^{24}$. Este mecanismo é uma somatória da ação das cerdas da escova e dos abrasivos constituintes do dentifrício empregado.

De maneira ideal, os abrasivos presentes nos dentifrícios deveriam ser relativamente inertes, de baixa dureza e distribuição adequada ${ }^{51,110}$, a fim de produzirem menor abrasividade, evitando situações como perda de material e aumento da rugosidade superficial.

Como conseqüência da perda de material restaurador, algumas das preocupações resultantes dizem respeito à perda de contorno, com exposição de margens, podendo levar à cárie secundária em virtude dos produtos bacterianos presentes, e sua possível ação tóxica que os componentes do material podem apresentar quando liberados no meio bucal ${ }^{31}$.

Já a rugosidade facilita a adesão e retenção de placa dental ${ }^{112,113}$, atuando negativamente tanto sobre a estrutura dentária como no tecido mole adjacente, determinando um potencial irritante mecânico, biológico e químico, por favorecer o acúmulo de microorganismos atuantes sobre os tecidos periodontais induzindo a problemas gengivais de maior ou menor intensidade. Além disso, a rugosidade da superfície pode afetar a reflexão da luz e o brilho implicando na perda do aspecto natural produzido pela restauração ${ }^{97}$, além de favorecer a descoloração e o manchamento. Certamente estas condições 
determinam a busca pela obtenção e manutenção de superfícies mais lisas das restaurações.

Existem vários métodos clínicos e laboratoriais para avaliar resistência à abrasão de materiais restauradores $8,12,16,25,29,39,41,46,51,57,72,76,77,87,111,115,116$. Como tal, é evidente observar como os testes clínicos vêm enfrentando questões de ordem ética, além de desvantagens como o tempo, os esforços necessários para conduzir a avaliação e os problemas associados com a quantidade de desgaste. Também a incapacidade para se interpretar os resultados no que diz respeito aos mecanismos que contribuem para o desgaste ${ }^{28,29}$, não sendo totalmente conhecidos.

Em contrapartida, os testes de escovação in vitro são válidos para se obterem dados comparativos sobre a resistência à abrasão das resinas compostas diretas, bem como para a verificação da qualidade da superfície resultante. A escovação simulada avalia um fator isolado, mas capaz de estabelecer um parâmetro do material quando à sua resistência, não indicando necessariamente a resistência a outros tipos de abrasão, como contato oclusal, atividades parafuncionais e dieta alimentar. Para isto, sempre haverá necessidade de se estabelecerem condições padronizadas capazes de serem relacionadas clinicamente ${ }^{76}$. A correlação entre a resistência à abrasão por escovação de estudos laboratoriais e clínicos pode ser constatada no trabalho de GIL et al. ${ }^{40}$ em 1999. 
Em vista de todas as afirmativas e considerações aqui apresentadas, decidiu-se desenvolver o presente trabalho, com o intuito de avaliar quantitativa e qualitativamente o desgaste e a rugosidade superficial de uma resina composta fotopolimerizável, após escovação simulada, em função de diferentes energias e fontes de luz usadas na polimerização. 
2 REVISÃO DE LITERATURA 


\section{REVISÃO DE LITERATURA}

O marco da odontologia quanto à investigação e preocupação em relação ao desgaste dentário é atribuído a $\operatorname{MILLER}^{73}$ (1907), o qual considerou os diversos fatores capazes de produzir este desgaste, como erosão, abrasão, atrição levando à exposição dentária, muitas vezes ocasionando defeitos em forma de cunha na região cervical dos dentes. $\mathrm{O}$ autor define desgaste como perda de substância, podendo ser do material restaurador ou do próprio elemento dental, sem considerar a etiologia envolvida. Em suas observações clinicas e laboratoriais, enfatizou a avaliação de ocorrência de desgaste por abrasão nos elementos dentários submetidos à escovação com grandes variações de escovas dentárias e sustâncias abrasivas aplicadas. Verificou-se menor desgaste em esmalte, quando comparado à dentina. Ao avaliar o desgaste em tecido dentário e averiguar a magnitude dos resultados, a curiosidade em relação aos materiais odontológicos restauradores o fez investigar o comportamento de restaurações de ouro fundido muito utilizado na época, também constatando o seu desgaste. Este trabalho iniciou uma serie de levantamentos e estudos referentes ao desgaste por escovação, considerando diferentes metodologia e substratos a serem pesquisados.

Neste contexto, as resinas acrílicas, comumente utilizadas na época, foram tomadas como substratos nos estudos de SEXSON; PHILLIPS ${ }^{97}$ (1951) investigando-se a conseqüência após a limpeza de próteses totais, onde se inclui a escovação com dentifrícios. Uma máquina Pepsodent foi empregada, 
aplicando-se escovas de cerdas macias de nylon a um período de 20.000 ciclos, considerando como um tempo clinico correspondente a dois anos. Para a análise, diferentes formas de avaliação foram aplicadas: perda de massa, alteração de brilho superficial, rugosidade superficial e microscopia eletrônica de varredura (MEV). Duas situações foram criadas: com os corpos-de-prova mantidos estáticos durante a escovação ou em movimento rotatório. Os resultados do teste piloto indicaram ação de desgaste associado apenas ao uso de abrasivos e não pela ação mecânica das escovas. Quando a perda de massa, nas duas situações, os dentifrícios em pó foram os que proporcionaram maior alteração de massa, sendo que as pastas originaram desgaste moderados. Pela microscopia eletrônica de varredura, evidenciou-se a presença de estrias e sulcos provocados pela ação abrasiva nas superfícies de resina acrílica. Os autores afirmaram que o ideal de se conciliar a ação desejada de limpeza sem modificações no substrato é de difícil controle, como demonstrado pela serie de análises realizadas.

Uma crescente preocupação com o decorrer dos anos foi notada em relação à abrasividade dos dentifrícios presentes no mercado e os danos que poderiam ocorrer nas superfícies dentárias. Neste sentido, GRABENSTETTER et al. ${ }^{41}$ (1958) propuseram-se a avaliar a influência de diferentes abrasivos nas superfícies dentárias, quando submetidos à uma máquina de escovação. Os espécimes a serem avaliados foram irradiados com isótopos $\mathrm{P}^{32}$, utilizados 
para marcação e posterior quantificação por meio leituras para a medição do desgaste ocorrido após um ensaio de escovação laboratorial. Os abrasivos testados foram: $\mathrm{CaCo}_{3}$, carbonato de cálcio, № $1(2,0 \mu \mathrm{m}), \mathrm{CaCo}_{3}$ № $2(1,8 \mu \mathrm{m})$, $\mathrm{CaHPO}_{4} .2 \mathrm{H}_{2} \mathrm{O}$, fosfato de cálcio dihidratado $(8,5 \mu \mathrm{m}), \mathrm{CaHPO}_{4}$ fosfato de cálcio $(11,4 \mu \mathrm{m})$, e $\mathrm{NaPO}_{3}$, metafosfato de sódio insolúvel $(7,4 \mu \mathrm{m})$, sendo o primeiro utilizado como referência. Foram utilizadas escovas de cerdas de nylon de média dureza a 200 ciclos por minuto, completando-se 2.000 ciclos, sendo a primeira metade escovada com o abrasivo padrão, e a outra escovada com um dos diferentes abrasivos propostos. Foi verificada abrasão tanto em dentina como esmalte. Em esmalte a abrasão foi significativamente menor, correspondendo a cerca de 1 a $5 \%$ do verificado em dentina. Os valores encontrados neste estudo foram comparados aos encontrados na literatura com o uso de medições de profundidade de rugosidade superficial, verificandose mesma ordem entre os abrasivos avaliados. Os autores acreditam que este teste é realizado mais facilmente, necessitando de menor tempo disponível, além de oferecer segurança. Em ordem crescente de abrasividade em dentina foi observada $\mathrm{CaHPO}_{4}, 2 \mathrm{H}_{2} \mathrm{O}, \mathrm{CaCo}_{3}$ № $2, \mathrm{CaCo}_{3} \mathrm{~N}_{0} 1, \mathrm{NaPO}_{3}, \mathrm{CaHPO}_{4}$.

VIEIRA $^{110}(1960)$ analisou a dureza e a resistência abrasiva frente à escovação em superfícies de resina acrílica. A influência da condição da polimerização e a existência de relação entre dureza e resistência à abrasão foram avaliadas. A abrasão foi promovida laboratorialmente por escovação 
simulada, testando duas marcas diferentes de resina acrílica, utilizando escovas de cerdas rígidas e flexíveis, água destilada, dentifrício em pasta e em pó, além do carbonato de cálcio em solução aquosa. Foi estabelecido que quanto maior a temperatura de polimerização, maior a dureza e a resistência à abrasão. Pela escovação, foi constatada perda do material por perda de massa. Quanto à resistência à abrasão da resina acrílica, foi observado que: 1a perda de massa e de reflexão é inversamente proporcional à temperatura de polimerização; 2- cerdas de consistência mais rígidas provocaram maior desgaste; 3- a ordem crescente de abrasividade avaliada foi água destilada, pasta, carbonato de cálcio e dentifrício em pó; 4- a ação isolada da escova promoveu o polimento da superfície e 5- houve diferença de comportamento quando da associação de dentifrício em pó e em pasta em relação ao desgaste.

Os dentifrícios sob condições de escovação normais, idealmente deveriam prover o máximo de limpeza e polimento e o mínimo de abrasão. Em 1968, STOOKEY; MUHLER ${ }^{101}$ realizaram vários estudos in vitro para avaliar a abrasividade de 43 dentifrícios sobre os tecidos dentários. Inicialmente, os dentes recém-extraídos foram irradiados e submetidos ao teste de abrasão numa maquina de escovação sob pressão de $150 \mathrm{~g}$, com 1.000 ciclos para a dentina e 3.000 para o esmalte, utilizando a técnica de Grabenstetter. Já, para a técnica de medição de abrasão pela perda de peso foram necessários 50.000 
ciclos. Muitas variáveis, como número de ciclos de escovação, pressão de escovação, tipo de abrasivo e lote, foram introduzidos nos experimentos. Os resultados mostraram que os valores de abrasão de esmalte aumentavam linearmente, até o emprego de 4.000 ciclos, e à medida que aumentava a pressão de escovação, aumentava também o desgaste tanto em dentina quanto em esmalte. Além disso, foi possível observar uma correlação positiva entre a técnica e perda de peso, quando comparada com a técnica de traçadores radioativos. Houve diferença significante dos valores da abrasão entre os abrasivos estudados; diferença entre as diversas marcas de dentifrícios que continham o mesmo tipo de agente abrasivo e diferença de abrasividade nos lotes de um mesmo dentifrício. Foram avaliadas também a capacidade de polimento, que diferiu muito entre os dentifrícios, e a capacidade de limpeza, sendo satisfatória para todos eles. Os resultados encontrados confirmaram a abrasividade decrescente das fórmulas tipo pó seguida pela do tipo pasta e, por fim, a do tipo líquida ou gel.

Superfícies de facetas de resina acrílica foram clinicamente avaliadas quanto à resistência à abrasão quanto submetidas a três diferentes dentifrícios, Gleem, Ultra Brite e Colgate. Este estudo foi conduzido por FACQ; VOLPE ${ }^{30}$ (1970) tendo a participação de seis pacientes do sexo masculino e feminino de boa higiene oral. Uma identação em forma de cruz foi realizada em cada superfície com cerca de 4 a $15 \mu \mathrm{m}$ de profundidade e de 3 a $4 \mathrm{~mm}$ em cada um dos lados da marcação. Uma análise em MEV foi efetuada antes e depois do 
tempo de avaliação. As superfícies selecionadas para o exame foram as regiões planas mais expostas ao processo da escovação. $O$ estudo foi procedido com duração entre três e sete semanas. A perda de substância por espécime foi calculada dividindo o total de perda da resina acrílica pelo número de braços efetivamente medidos. Pelos resultados, foi concluído não haver diferenças entre os três dentifrícios utilizados no estudo, os quais produziram pequeno efeito de desgaste nas superfícies de resina acrílica, sem significância clinica. O método utilizado in vitro de réplica associado ao MEV teve papel fundamental na determinação da real abrasividade dos dentifrícios.

HELTH; WILSON ${ }^{45}$ (1976) desenvolveram um método laboratorial para medir abrasão dos materiais restauradores pela associação escova de dente e dentifrício. No testes, foi utilizada uma máquina de abrasão que consistia de um motor que movimentava um jogo de engrenagens e hastes, cujas extremidades eram fixadas às cabeças das escovas de dente de consistência macia. O dentifrício de carbonato de cálcio foi diluído para simular a saliva e reduzir a sedimentação do abrasivo, e então colocado em um recipiente, onde também eram fixados os espécimes a serem analisados (materiais restauradores: ouro, amálgama, silicatos e resinas). Em uma primeira fase, todos os espécimes foram submetidos à abrasão a $37^{\circ} \mathrm{C}$, usando $5 \mathrm{~N}$ de pressão, em um movimento de $45 \mathrm{~mm}$ da escova e velocidade de 4 a 5 movimento por segundo, até totalizar 20.000 ciclos. O teste propriamente dito, foi conduzido 24 horas depois e consistiu de 20.000 movimento, o equivalente 
a dez meses de desgaste na boca, usando um novo jogo de três escovas, que eram movidas de recipiente para recipiente, para que cada espécime recebesse um número igual de movimentos de cada escova. A análise foi efetuada através de um perfilômetro Talysurf, com o qual pôde se avaliar a quantidade de material removido dos corpos de prova. O trabalho também discutiu alguns fatores que poderiam influenciar os resultados como: idade das escovas, comprimento do movimento, pressão aplicada e temperatura.

O desgaste das faces oclusais de restaurações de compósitos apresentava resultados desanimadores por várias observações realizadas. A abrasão oclusal de um compósito restaurador de micropartícula de $\mathrm{SiO}_{2}$ (Sílica) foi determinada por JORGENSEN; ASMUSSEN ${ }^{54}$ (1978). Amálgama, resina compostas de carga convencional, resina sem carga e misturas destes compósitos, resultando em resina experimental, foram avaliados. Após 21 a 25 meses, com intervalo de seis meses, o desgaste foi medido pela média de altura das paredes expostas, pela presença ou ausência de estrias decorrentes do polimento e observações em MEV. Não houve exposição de margem nas restaurações com a resina composta experimental. Ao contrário dos demais materiais testados, a resina experimental foi à única que preservou as estrias produzidas pelo polimento. Os resultados indicaram a influência da carga no comportamento frente ao desgaste, além da melhor preservação da superfície polida. 
A avaliação da abrasão provocada por 23 marcas comercias de dentifrícios sobre placas de plex-glass, submetidas à escovação mecânica com escovas macias (Multi-Cerdas) foi realizada por PANZERI et al. ${ }^{82}$ (1979). O tempo de escovação na máquina tipo Pepsodent foi de 60 minutos para todos os corpos-de-prova, que mediam $88 \times 27 \mathrm{~mm}$. Os corpos-de-prova foram pesados antes e após o ensaio de escovação, e a perda de peso variou de 0,0233g para aqueles escovados com Ultra Brite até $0,0023 \mathrm{~g}$ para aqueles escovados com água. Também foram feitos registros fotográficos, com 20 vezes de aumento, sendo que os valores quantitativos de perda de peso foram comparáveis aos visualizados nas fotografias. Os autores sugeriram que, do ponto de vista de higienização dos dentes, o ideal seria o uso de dentifrícios abrasivos intercalados com aqueles não abrasivos, já que as exigências que são feitas aos dentifrícios é que ele devem limpar e polir os dentes, melhorar o estado gengival, eliminar os depósitos de mancha e tártaro, reduzir a placa bacteriana e prevenir a cárie e as periodontopatias sem riscar ou desgastar exageradamente o esmalte e a dentina, irritar a mucosa gengival ou alterar os materiais restauradores.

Em 1980, foi proposto um teste laboratorial de abrasão para resinas compostas por EHRNFORD et al. ${ }^{28}$ que afirmavam serem os testes clínicos de longa duração os mais fiéis para este tipo de estudo. No entanto, há desvantagens de tempo requerido, dificuldade na quantificação do desgaste e 
inabilidade de interpretação dos resultados com relação aos mecanismos responsáveis por gerar o desgaste. Os autores relataram a combinação do teste a dois corpos com uma mistura aquosa de pérolas de vidro e partículas abrasivas, para o desgaste não ocorrer apenas por abrasão, más também por fadiga, corrosão e desgaste adesivo. Os corpos-de-prova foram confeccionados em uma matriz de $5 \mathrm{~mm} \times 10 \mathrm{~mm}$ com uma superfície curva, armazenados em água a $37^{\circ} \mathrm{C}$ por uma semana e submetidos ao teste, em que foram colocados em um disco circular preso em quatro braços. O motor programado para girar $2,5 \mathrm{~mm}$ em cada direção, com uma pausa de 15 segundos por uma hora, fazia o movimento do disco a uma velocidade de 1,4m/seg. A quantidade de abrasão foi expressa pela diferença entre a altura do corpo-de-prova antes e após o ciclo, e a verificação da superfície abrasionada foi feita utilizando-se a microscopia eletrônica de varredura. Concluíram que o teste é importante porque apresentou a mesma ordem de desgaste observada clinicamente, porém, deve ser usado com ressalvas, apenas entre grupos de materiais onde a diferença na composição não possa afetar significativamente o mecanismo de desgaste.

$\operatorname{AKER}^{1}(1982)$ publicou um trabalho de comparação da resistência à abrasão por escovação de resinas compostas e as características das superfícies abrasionadas. Apesar dos materiais testados serem diferentes, a metodologia é semelhante a do presente estudo. A máquina de escovação 
possuía uns motores elétricos, responsáveis pela movimentação de quatro hastes em cujas extremidades se posicionavam as cabeças das escovas dentárias. Reservatórios continham uma base de metal resistente à abrasão onde se localizavam os corpos-de-prova e a mistura abrasiva (45g de Colgate MFP e $45 \mathrm{ml}$ de água destilada). A capacidade do motor era de 16.000 ciclos de escovação por uma hora, o que corresponde a 22 ciclos de escovação, duas vezes ao dia, por um ano. A resistência à abrasão foi medida pela determinação do volume de material perdido durante o teste. Os materiais testados foram mantidos imersos em água a $37^{\circ} \mathrm{C}$ até que atingissem um estado máximo de absorção. Os espécimes eram pesados tirando o excesso de água, a cada 24 horas, e o peso era considerado constante quando, após cinco pesagens consecutivas, variasse no máximo $0,1 \mathrm{mg}$. No estudo, os corpos foram escovados por 15 horas, trocando as escovas e mistura em um intervalo de cinco horas. Foram utilizadas micrografias eletrônicas das superfícies abrasionadas para ilustrar as características das superfícies de cada material e observou-se a ocorrência de estrias e ondulações na maioria delas, causada pela aplicação repetitiva e unidirecional das escovas.

HARRINGTON et al. ${ }^{43}$ (1982) apresentaram um método para medir a ação abrasiva da escovação sobre os materiais restauradores. A máquina de escovação consistia de um cabo central horizontal de secção hexagonal que, ligado a um motor, rodava a uma velocidade de 120 rpm por 25 segundos, com uma parada de cinco segundos, para depois fazer o mesmo no sentido 
contrário. A cada seis segundos o cabo movimentava-se no seu longo eixo por $2 \mathrm{~mm}$. A solução de $100 \mathrm{ml}$ de dentifrício foi mantida a $37^{\circ} \mathrm{C}$ numa cuba situada sob cabo central, no qual foram afixadas 18 escovas Oral B 60, de tal forma que uma projeção de $2 \mathrm{~mm}$ dos tufos das mesmas esfregassem os corpos-deprova ciclicamente e que cada espécime sofresse escovação por três escovas. Foram utilizadas 17 marcas comerciais de materiais restauradores (amálgama, iônomero de vidrio, silicato, selante, compósito convencional, de micropartículas e resina sem carga) para confeccionar seis corpos-de-prova para grupo, com 10mm de diâmetro e $1 \mathrm{~mm}$ de espessura, em matrizes de Teflon, de tal forma que quando posicionados na máquina de escovação estabelecessem um posicionamento de 0,5mm acima da base. Os materiais foram manipulados de acordo com as instruções do fabricante, sendo que o silicato, os iônomeros de vidro e as resinas de auto e fotopolimerização tomaram presa sob uma tira de matriz de acetato de celulose. A seguir, o silicato e os iônomeros foram mantidos a $37^{\circ} \mathrm{C}$ e $95 \%$ de umidade relativa do ar por 24 horas, para depois serem submersos em água destilada a $37^{\circ} \mathrm{C}$, juntamente com os outros materiais. Após sete dias, os corpos-de-prova foram secos com um tecido, pesados e tiveram a sua rugosidade inicial medida com o Talysurf 4, bem como a espessura, usando um micrometro. Então, os corposde-prova foram submetidos a 60.000 ciclos de escovação, quando tiveram novamente sua rugosidade, peso e espessura medidos. A perda de densidade foi calculada dividindo-se a perda de peso pelo peso original e multiplicando-se 
esse resultado pela espessura original. Os resultados mostraram que as resinas sem carga mantiveram sua lisura, o único material que melhorou a lisura foi o amálgama, enquanto todos outros, partindo de uma boa lisura, tornaram-se muito mais rugosos após a escovação. Os materiais que menos perderam em densidade foram os compósitos convencionais juntamente com o silicato e o amálgama, seguindo pelos iônomeros de vidrio, selantes resinosos, resinas sem carga e compósitos de micropartículas. Não foi possível definir uma correlação entre a rugosidade final e a perda de material.

A influência de fatores estruturais e físicos no desgaste por escovação em resina composta foi analisada, por DE GEE; HARDEL-HAGENNAR; DAVIDSON $^{25}$ (1985). Amálgama, resina sem carga, resina de base de prótese total, esmalte e dentina humana foram testados para comparação. Superfícies foram obtidas por diferentes técnicas: 1- contra lâmina de vidro, 2- discos de óxido de alumínio a seco de imediato e mediato (após quatro semanas de armazenamento seco a $37^{\circ} \mathrm{C}$ ) e 3 - material polimerizado em boca por diferentes temperaturas. A escovação foi realizada com pasta Prodent sob carga de $125 \mathrm{~g}$ a 2.600 ciclos por hora, correspondente a um mês. A cada meia hora a solução foi renovada. Um perfilômetro foi empregado para a análise das superfícies em Ra. As resinas de micropartículas apresentaram desgaste 5 a 10 vezes mais rápido que as convencionais. As superfícies das resinas compostas obtidas em bloco apresentaram-se mais resistentes. $\mathrm{O}$ tratamento 
com aquecimento posterior até $225^{\circ} \mathrm{C}$ proporcionou maior resistência. Foi verificada a deterioração quando do uso do polimento a seco em alta velocidade, com temperatura acima de $225^{\circ} \mathrm{C}$. O polimento mediato demonstrou maior resistência em comparação ao imediato.

Em uma revisão da literatura falando da abrasão ocasionada pelos dentifrícios e pastas profiláticas sobre o tecido dentário e materiais restauradores, BARBAKOW; LUTZ; IMFELD ${ }^{8}$ (1987) afirmaram que a marcação radioativa e a perfilometria superficial são os métodos mais largamente utilizados para avaliar o desgaste, entretanto estes também podem ser feitos através de perda de massa.

RATANAPRIDAKUL et al. ${ }^{88}$ (1989) estudaram o comportamento das resinas compostas em relação ao desgaste, quando utilizadas em dentes posteriores. Destacaram os fatores importantes neste comportamento, especialmente o tamanho da carga inorgânica. Os autores destacam que as resinas do tipo microfill tendem a ser mais resistentes pois contém partículas de até $1 \mu \mathrm{m}$. O acabamento pode determinar a formação de microtrincas, tornando a superfície mais susceptível ao desgaste. Também salientam que a rugosidade superficial das resinas compostas diminui a resistência do material e pode acelerar seu desgaste. Para os autores a média anual de desgaste das resinas para dentes posteriores está em torno de $25 \mu \mathrm{m}$.

Para LEINFELDER ${ }^{62}$ (1993) o pequeno grau de desgaste observado nas resinas compostas deve-se às modificações ocorridas nos materiais, que 
passam pelo tamanho da carga de 100 para 5 micrômetros, resultando em diminuição de cerca de $50 \%$ do desgaste. Para o autor, a mudança da carga de quartzo para vidros moles tais como o bário, estrôncio e o silicato de alumínio de lítio, faz com que o impacto da mastigação seja mais bem assimilado, o que não ocorria quando a carga era de quartzo. Além disso, o pesquisador salienta que outra tendência importante foi o arredondamento das partículas o que diminuiu a concentração de estresse entre o material de carga e a matriz orgânica. Estas alterações levaram a uma profunda diminuição no desgaste, reduzindo de $150 \mu \mathrm{m}$ ao ano para cerca de $8 \mu \mathrm{m}$. Neste mesmo contexto, o trabalho de DICKINSON et al. ${ }^{26}$ (1990) concluiu que o desgaste médio das resinas por ano é de $10 \mu \mathrm{m}$ ou pouco mais. As causas para extraordinária evolução seriam as ligações mais fortes entre a matriz orgânica e as partículas de carga e otimização do tamanho das partículas.

MATSUMURA; LEINFELDER ${ }^{70}$ (1993), quantificaram o desgaste in vitro de seis marcas de resinas compostas fotoativadas e uma resina acrílica. Após 100.000 ciclos de desgastes, os valores estiveram em torno de $86 \mu \mathrm{m}$, o que foi considerado pelos autores como bastante reduzido. Neste sentido, no mesmo ano WILLEMS et al. ${ }^{115}$ discorreram sobre a correlação existente entre as avaliações clinicas in vivo e in vitro, dizendo serem muito controversas. As restaurações foram avaliadas nas áreas de contato e de não contato. Após cinco anos de acompanhamento, a maioria das resinas compostas apresentaram um desgaste médio de $110 \mu \mathrm{m}$ a $149 \mu \mathrm{m}$. Os autores afirmaram 
que a resina como P30, P30 APC (Advanced Particle Coumpling) e P50 APC, pode ser considerada como alternativas para o amálgama.

O exato mecanismo de desgaste na área de contato oclusal de restaurações dentárias não é totalmente compreendido. Podem ser consideradas uma combinação de abrasão, adesão, desintegração química e fadiga da superfície. Com o intuito de simular esses quatro tipos de desgaste em combinação, KREJEI; LUTZ; ZELDER ${ }^{60}$ (1992) realizaram um estudo e avaliaram o efeito da dimensão da área de contato no desgaste de espécimes de materiais e no desgaste das cúspides de esmalte antagonistas. Trinta e seis espécimes cilíndricos de resina composta foram posicionados em cavidades de $8 \mathrm{~mm} \times 2 \mathrm{~mm}$ e divididas em cinco grupos, cada qual submetido a uma determinada medida de área de contato oclusal. O experimento consistiu das seguintes etapas: armazenamento dos espécimes em solução aquosa de etanol a 75\% por 24 horas; abrasão por teste de escovação com força de $2 \mathrm{~N}$ por 30 minutos, utilizando-se uma mistura de duas partes de dentifrício para uma parte de água; 300 ciclos de termociclagem em água $\left(5^{\circ}\right.$ a $\left.55^{\circ} \mathrm{C}\right)$ simultaneamente a 120.000 mordidas oclusais, através de molares superiores humanos extraídos, com freqüência de $1,7 \mathrm{~Hz}$ e força máxima de $53 \mathrm{~N}$. O mais severo desgaste da resina composta foi encontrado no espécime cujo antagonista possuía esmalte com menor área de contato, logo a extensão e o mecanismo de desgaste foram relacionados com a pressão da mordida, que era determinada pela dimensão da área de contato. 
Considerando quais fatores podem influenciar a longevidade das restaurações em resina composta, PEUTZFELDT ${ }^{84}$ (1994) introduz uma nova variável na metodologia do estudo de desgaste. A autora menciona que um dos principais elementos que influencia o desempenho clínico e o comportamento mecânico das restaurações em compósito é a qualidade da luz ativadora. A eficácia da polimerização é refletida pelo grau de conversão, isto é, pelo número de duplas ligações nos grupamentos metacrilatos que reagiram durante a polimerização. Um alto grau de conversão e suficiente profundidade de polimerização dependem não só da quantidade de luz, mas também da sua qualidade, ou seja, do comprimento de onda da luz. Neste trabalho a autora avaliou a habilidade de um medidor de intensidade de luz - radiômetro - da marca CL-Tester, em predizer o grau de conversão de uma resina. Uma resina composta fotoativada foi elaborada com 25mol-\% BISGMA e 75mol-\% TEGMA. A resina foi fotoativada com uma das cinco diferentes unidades de fotoativação, cujas intensidades variavam de pobre a muito boa, registrada pelo radiômetro. Uma das cinco unidades ativadoras era nova (Translux CL), duas eram usadas (Visilux 2 e Luxor) e duas foram deliberadamente danificadas para que ficassem menos eficazes (Heliomat e Command II). O grau de conversão foi determinado pelo número de duplas ligações remanescentes (Remainig Double Bonds- RDB) por meio do espectro de transmissão por infravermelho da resina, sendo o grau de conversão o resultado da subtração da \% de RDB de $100 \%$. Os cinco valores médios de RDB variaram com significância estatística. O 
efeito da luz é influenciado pela quantidade de resina, sistemas iniciadores, tipo de quantidade de carga e pigmentos, o que significa que as cinco unidades fotoativadoras poderiam não ter dado os mesmos valores para números de RDB como encontrado neste estudo, se tivesse sido utilizada outra resina. Entretanto, para qualquer resina, pode ser encontrada a correlação entre o CLTester e o seu grau de conversão. A autora conclui que o CL-Tester se mostrou adequado para predizer o grau de conversão e a profundidade de polimerização, de maneira que poderia constituir um meio útil de controle regular de unidade ativadoras para a pratica odontológica.

CAUGHMAN; RUEGGERBERG; CURTIS JR. ${ }^{22}$ (1995) avaliaram a interdependência entre intensidade de luz, com lâmpada halógena, da fonte ativadora e o tempo de exposição na polimerização de resinas compostas (Silux-Plus e P50), em diferentes profundidades. A intensidade de luz do aparelho testado foi reduzida de $800 \mathrm{~mW} / \mathrm{cm}^{2}(100 \%)$ para 578,400 e 233 $\mathrm{mW} / \mathrm{cm}^{2}(29,2 \%)$ utilizando filtros seletores verificando, periodicamente, a intensidade com um radiômetro. Os espécimes foram ativados pelos tempos de 20, 40, 60 e 80 segundos, após o que eram secionados em discos de 1, 2 e $3 \mathrm{~mm}$ a partir da superfície de topo, e então examinados por meio de espectroscopia infravermelha 24 horas após a polimerização. Os resultados foram submetidos à análise estatística, permitindo aos autores concluir que: 1a utilização de um tempo de 60 segundo para que ocorra uma polimerização 
uniforme, a fim de compensar intensidade inferior a $400 \mathrm{~mW} / \mathrm{cm}^{2}$, é considerada a mínima ideal; 2- a espessura máxima de cada incremento de resina deve ser de $2 \mathrm{~mm}$, para que haja uma polimerização satisfatória, mais uniforme e menos susceptível a mudanças de intensidade de luz; 3- exposição de 20 segundos promoveu polimerização inadequada para profundidades iguais ou maiores a 1mm; 4- recomendam, ainda, que aparelhos que forneçam $233 \mathrm{~mW} / \mathrm{cm}^{2}$ de potência devem ter suas lâmpadas trocadas, pois tal intensidade foi insatisfatória para a polimerização de camadas de $2 \mathrm{~mm}$ espessura.

A resistência ao desgaste e a dureza Knoop de resina composta com relação à cor e a fonte ativadora foram avaliadas por MEIRA; CARDOSO ${ }^{71}$ (1996). Utilizaram-se duas cores da resina composta TPH: incisal (cor mais clara) e XGB (cor mais escura). A fotoativação foi feita com os aparelhos de lâmpada halógena Visilux ou Primelite. Os teste de dureza Knoop foram realizados em discos de resinas de $1 \mathrm{~mm}$ de espessura nos quais produziramse penetrações nas porções tanto superiores quanto inferiores. Também foram executados testes de resistência ao desgaste em uma máquina de ciclagem mecânica, cujos espécimes eram molares hígidos embutidos em pequenos anéis de plástico. Nestes realizou-se cavidades padronizadas, posteriormente foram preenchidas com a resina composta. Após 16.000 ciclos foi realizada a análise do desgaste por meio indireto comparando os modelos em gesso dos 
corpos-de-prova com réplicas, também em gesso, dos padrões da escala M-L. A análise dos resultados permitiu concluir que: 1- no teste de dureza, a cor incisal apresentou valores maiores e mais uniformes quanto comparada com a cor XGB; 2- no teste de desgaste não houve diferença estatisticamente significante entre as variáveis estudadas.

AZEVEDO; CATRAMBY; FRANCO ${ }^{7}(1997)$ investigaram a profundidade de polimerização de resinas compostas por diferentes aparelhos fotopolimerizadores em diferentes intensidades. Uma associação de testes de raspagem e dureza superficial foi utilizada nesta mensuração. Para tal, um disco de dureza Demetron correspondente à dureza de Baracol 75 sob pressão constante sobre o espécime foi aplicado como referência. Os autores concluíram pelos resultados obtidos que existe uma relação de profundidade de polimerização com intensidade de luz, sem no entanto haver diferenças estatisticamente significante entre os aparelhos fotopolimerizadores avaliados, com intensidade oscilando entre 100 e $500 \mathrm{~mW} / \mathrm{cm}^{2}$, apesar da sugestão de intensidade superior a $200 \mathrm{~mW} / \mathrm{cm}^{2}$ por parte dos fabricantes.

Resultados semelhantes foram obtidos por MARAIS et al. ${ }^{69}$ (1997) os quais consideraram que um aumento na intensidade de luz é capaz de produzir maior dureza na superfície de resinas compostas. Com base nesta afirmativa, desenvolveram uma pesquisa onde se propuseram a determinar a profundidade de polimerização produzida por duas unidades fotoativadoras 
com diferentes intensidades de luz (300 e $600 \mathrm{~mW} / \mathrm{cm}^{2}$ ). Os espécimes foram confeccionados em resina da marca Filtek ${ }^{\mathrm{TM}}$ Z-100 (3M/ESPE) utilizando-se matrizes metálicas com espessuras de 1, 2, 3, 4 e 6mm e perfurações de 5mm de diâmetro, divididos em dois grupos de 10 espécimes cada, um grupo fotoativado com 300 e o outro com $600 \mathrm{~mW} / \mathrm{cm}^{2}$. As bases dos espécimes foram submetidas à teste de microdureza Vickers imediatamente e 1 hora após a fotoativação. Os resultados, após análise estatística, mostraram que à medida que aumentava a espessura, diminuía a dureza Vickers. Foram encontradas diferenças estatisticamente significantes entre todos os grupos, em ambos os tempos de leitura, entre as diferentes intensidades de luz e entre os grupos de 2 e $3 \mathrm{~mm}$ de espessura. Estes resultados possibilitaram aos autores concluírem que: 1- as resinas compostas fotoativadas devem ser utilizadas em porções e fotoativadas em camadas incrementais, não devendo exceder $2 \mathrm{~mm}$ de espessura; 2- na prática, o acabamento e polimento das restaurações de resina deveriam ser adiados e as mesmas não deveriam ser submetidas a esforços oclusais antes da maturação da adesão; 3- nas condições deste estudo, o aumento da intensidade de luz não conduziu a uma melhor conversão em espessuras maiores que $2 \mathrm{~mm}$; 4 - a luz na intensidade de $600 \mathrm{~mW} / \mathrm{cm}^{2}$ permitiu maiores números de dureza Vickers na espessura de $2 \mathrm{~mm}$ que a de $300 \mathrm{~mW} / \mathrm{cm}^{2}$. 
Além da espessura do material e o tipo de fonte de luz para a realização das restaurações em resinas compostas, o tratamento da superfície é essencial para a performance clínica dos procedimentos restauradores diretos. Por esta razão, torna-se muito importante o conhecimento do trabalho de ONO ${ }^{80}$ (1997). O autor, partindo de diferentes tratamentos de superfície avaliou o comportamento após escovação simulada in vitro das resinas fotopolimerizáveis Herculite XVR, Z100 e Tetric. Para cada material, foram confeccionados 56 corpos-de-prova de $8 \mathrm{~mm}$ de diâmetro x $2 \mathrm{~mm}$ de espessura, obtidas pela técnica incremental. As amostras foram armazenadas em estufa a $37^{\circ} \mathrm{C}$ e umidade relativa de $100 \%$ por 24 horas. Os grupos $\mathrm{A}$, B e C receberam o acabamento com brocas de 3 lâminas e os grupos D, E e F foram tratados com pontas diamantadas F e FF. Em seguida, deu-se o polimento das amostras: os grupos A e D foram polidos com Enhace + Prismas Gloss, os grupos B e E polidos com abrasivos de silicone Viking (cinza e verde) + Gel e os grupos C e F polidos com discos Soft-lex (fino e extrafino). Para o ensaio de escovação, metade de cada grupo foi submetido à escovação apenas com água destilada e foram consideradas controle. A outra metade foi escovada com a associação do dentifrício Kolynos Super Branco. Foram utilizadas máquinas de escovação Elabor, escovas Oral- B 30, com a velocidade de 250 movimentos por minuto durante duas horas, totalizando 30.000 ciclos por amostra e carga axial de 200g. Para a avaliação dos resultados um perfilômetro Prazis-Rug-3 registrou os valores em Ra. Pela análise estatística 
dos resultados e fotomicrografias realizadas, concluiu-se que independente do compósito, as que foram obtidas a partir da tira de poliéster apresentaram-se mais lisas, mesmo após a escovação com água e com água e dentifrício . A maior média de rugosidade superficial foi obtida quando utilizada as pontas diamantadas F e FF + abrasivos de silicone Viking e gel + dentifrício, em todas as resinas avaliadas. A escovação com dentifrício produziu resultados mais críticos em todos os casos em restaurações polidas mecanicamente.

Ainda em 1998, FERREIRA et al. ${ }^{34}$ propuseram-se avaliar as resinas híbridas Tetric, Prisma TPH, Z100 e Glacier para análise de desgaste de acordo com a rugosidade superficial encontrada antes e após a escovação. Dez amostras de cada grupo foram submetidas a 100.000 ciclos. Todos os materiais testados apresentaram aumento na rugosidade final, sendo em ordem crescente, Prisma TPH, Glacier, TPH e Z-100, com diferenças estatisticamente significantes entre as resinas Prisma TPH e Tetric, Prisma TPH e Z-100 e Z-100 e Glacier.

Como é sabido, existem no mercado odontológico inúmeras opções em termos de aparelhos de fotoativação para a polimerização de materiais resinosos. Por esta razão, FRIEDMAN et al. ${ }^{38}$ (1999) destacam que os cirurgiões dentistas precisam entender a química dos materiais, a dinâmica de polimerização, os fatores de estresse criados e as exigências necessárias para se obter os melhores resultados. Após estudar as novas opções de luz fotoativadora para restaurações de resina composta, afirmam que se um clínico 
opta em usar algum sistema de polimerização não tradicional, ele necessita consultar o fabricante para determinar o espectro de luz do sistema, e contactar o fabricante da resina composta para se assegurar de que o material usado pode ser adequadamente polimerizado com a fonte de luz escolhida. Os fabricantes têm serviço de atendimento ao cliente que normalmente tem um grande conhecimento sobre seus produtos. Além disso, ressaltam ser promissor os mais recentes desenvolvimentos tecnológicos baseados em experiências laboratoriais e relatos de casos clínicos. Contudo, ainda existe a necessidade de realização de estudos clínicos multidisciplinares para provar sua segurança e eficácia. Desse modo, os clínicos poderão tomar decisões com mais base científica, possibilitando-os proporcionar a seus pacientes uma odontologia de qualidade.

Continuando com este raciocínio, LEINFELDER ${ }^{65}$ (1999) questionou qual seria a melhor intensidade da luz de fotoativação. Segundo o autor, vários fabricantes recomendam os fotoativadores com alta intensidade de luz. Más são também comumente aceito que é necessária uma quantidade mínima de intensidade para garantir uma ótima polimerização. Tem sido muito recomendado que o clinico monitore freqüentemente a intensidade da sua luz fotoativadora usando um radiômetro para garantir o sucesso clínico. Nos últimos anos, varias publicações têm recomendado uma intensidade mais alta (em torno de $250 \mathrm{~mW} / \mathrm{cm}^{2}$ ) por 10 segundos e então irradiado a uma 
intensidade mais alta (cerca de 650 a $850 \mathrm{~mW} / \mathrm{cm}^{2}$ ) por 20 segundos. Vários novos aparelhos fotoativadores vêm sendo produzidos para promover este objetivo de duas maneiras: um tipo gera dois níveis distintos de radiação e outro produz um nível mais baixo de luz seguido por um aumento gradual - ou em rampa - da luz até um nível definido de intensidade. Esta nova proposta relaciona a distribuição de vetores de tensão ou o posicionamento da tensão máxima dentro da restauração, que ocorre como resultado do processo de polimerização. Uma aplicação inicial de irradiação de alta intensidade pode causar um aumento da tensão na interface dente/restauração, mais comumente ao longo das margens oclusais cavo-superficiais, podendo potencialmente haver a formação de fendas. O uso de baixa intensidade de luz para polimerizar uma restauração de resina composta resulta em uma distribuição mais uniforme dos vetores de força, uma transferência de resina ainda plástica para os pontos onde a contração de polimerização foi maior e um maior potencial para adaptação marginal. Existe uma séria evidência de que o processo de polimerização em dois passos contribua muito com uma melhor adesão, particularmente à superfícies dentinárias. Finalmente, o autor conclui afirmando ser interessante se observar os novos sistemas de luz fotoativadora que venham a aparecer no mercado.

Dentro deste mesmo contexto, RUEGGEBERG ${ }^{91}$ (1999) publica uma revisão sobre o processo de polimerização, variedades de aparelho fotopolimerizadores existentes no mercado e as diferenças entre as filosofias 
pertinentes à polimerização. A tendência é que o rótulo da resina composta traga informações sobre a energia necessária para a polimerização. Da mesma forma, o aparelho fotoativador deve indicar a intensidade de luz e comprimento de onda emitido. $\mathrm{O}$ espectro necessário para uma resina deve combinar com o espectro de luz emitido pelo aparelho, pois do contrário, não haverá fotopolimerização. $\mathrm{O}$ autor define um conceito sobre energia total de polimerização. A analogia é feita com um filme fotográfico, onde o tempo de exposição é variado de acordo com as condições de luz do ambiente e com a sensibilidade do filme a ser usado (a ASA ou número ISO). Um filme mais sensível vai necessitar de tempos de exposição mais curtos em níveis menores de iluminação do que filmes de menor sensibilidade. Para calcular esta energia total, é necessário saber a intensidade da unidade fotoativadora $\left(\mathrm{em} \mathrm{mW} / \mathrm{cm}^{2}\right)$ e a duração do tempo de exposição (em segundos). Considerando-se uma resina que necessite de uma exposição de $40 \mathrm{~s}$ a $600 \mathrm{~mW} / \mathrm{cm}^{2}$ para propiciar adequada polimerização em $2 \mathrm{~mm}$ de profundidade, 0 total de energia concedida é o produto de $40 \mathrm{~s} \times 600 \mathrm{~mW} / \mathrm{cm}^{2}$ ou $24000 \mathrm{~mJ} / \mathrm{cm}^{2}\left(24 \mathrm{Jcm}^{2}\right)$. Desta forma, qualquer combinação de exposição e intensidade que resulte em $24 \mathrm{~J} / \mathrm{cm}^{2}$ deve propiciar a mesma qualidade na polimerização.

Com o objetivo de testar a hipótese de que aparelho à base de LEDs produz profundidade de polimerização semelhante à lâmpada halógena, MILLS; JANDT; ASHWORTH ${ }^{74}$ (1999) avaliaram o grau de polimerização de 
três resinas compostas fotoativadas com LED $\left(290 \mathrm{~mW} / \mathrm{cm}^{2}\right)$ e luz halógena $\left(455 \mathrm{~mW} / \mathrm{cm}^{2}\right) . \mathrm{Na}$ introdução do trabalho mencionou-se que os aparelhos à base de LEDs apresentam uma vida útil bastante longa (10.000 horas), não requerem filtro, são bastante resistentes à choques ou vibrações e emitem energia luminosa dentro do espectro de absorção da canforoquinona. $O$ aparelho deste estudo foi montado com 25 LEDs, sendo a luz conduzida por uma ponteira à base de polímero. Diante dos resultados, foi verificado que o LED proporcionou uma maior profundidade de polimerização do que a lâmpada halógena. Os autores atribuíram estes dados ao fato da energia emitida estar toda concentrada no comprimento de onda ideal para absorção da canforoquinona. Foi relatado que o LED produz baixa densidade de potência, quando comparado com os aparelhos convencionais (halógena), todavia com possibilidade de proporcionar graus de polimerização semelhantes ou maiores aos alcançados com lâmpada hológena.

Levando em consideração a importância do tempo de exposição e intensidade de luz dos aparelhos de fotoativação, JANDT et al. ${ }^{50}$ (2000) testaram a hipótese de que a profundidade de polimerização e resistência à compressão das resinas compostas, polimerizadas com LED e com LH, não diferiram significativamente. $\mathrm{O}$ segundo objetivo consistia em caracterizar a irradiação e o espectro de luz emitido por ambas as fontes a fim de permitir comparações entre as mesmas. Empregou-se a resina Spectrum TPH nas cores A2 e A4, polimerizada por 40s com ambas as fontes. Os aparelhos 
usados foram um conjunto de 27 LEDs azuis (Nichia Chemical Ind. Ltda, Japão) com $6 \mathrm{~mm}$ de diâmetro da fonte de luz e o aparelho de LH Spectrum modelo 201R (Dentsply De Trey GmbH, Alemanha) com 9mm de diâmetro na fonte de luz. Foram verificados a potência de saída dos aparelhos, com medidor científico de potência (Coherent 210 Coherent Ltd Cambridge. UK) e o espectro de emissão, com o aparelho MS 1271 e o detector de irradiação IVCCD (LOT Oriel, Leather-head, Surrey. UK). Dessa forma, mediu-se a distribuição da intensidade de luz emitida através do espectro, preferivelmente a que se obtém com um radiômetro comercial, o qual mede a intensidade de luz emitida nos comprimentos de onda determinados pelo filtro do mesmo. Mensurou-se a profundidade de polimerização em 10 amostras de cada cor, com $4 \mathrm{~mm}$ de diâmetro e $8 \mathrm{~mm}$ de espessura, por meio de um penetrômetro. Compararam-se os resultados usando o teste t-Student. A resistência à compressão foi determinada depois de 6 e 72 horas. A irradiação emitida foi de $755 \mathrm{~mW} / \mathrm{cm}^{2}$ e $350 \mathrm{~mW} / \mathrm{cm}^{2}$ para LH e LED, respectivamente. O aparelho de LH apresentou uma extensa distribuição de irradiação no espectro, com pico em longos comprimentos de onda e uma extensa continuidade para região de comprimentos mais curtos, sendo que $95 \%$ da irradiação total estiveram entre $398 \mathrm{~nm}$ e $507 \mathrm{~nm}$ concentrado-se em $497 \mathrm{~nm}$. O LED, por outro lado, teve um pico único máximo de $465 \mathrm{~nm}$ com $95 \%$ de irradiação concentrada entre 438nm e $501 \mathrm{~nm}$. Os resultados mostraram que a $\mathrm{LH}$ polimerizou as resinas mais profundamente $(6,40 \mathrm{~mm}$ A2 e $5,19 \mathrm{~mm}$ A4) do que o LED $(5,33 \mathrm{~mm}$ A2 e 
$4,27 \mathrm{~mm} \mathrm{A4).} \mathrm{No} \mathrm{entanto,} \mathrm{segundo} \mathrm{o} \mathrm{fabricante} \mathrm{e} \mathrm{as} \mathrm{normas} \mathrm{ISO} \mathrm{4049,} \mathrm{ambas}$ unidades polimerizaram os compósitos mais profundamente do que o necessário.

MOMOI et al. $^{77}$ (2000) avaliaram a resistência à abrasão e a dureza Knnop das resinas compostas Herculite XRV e Z100 e de alguns cimentos ionoméricos. Foram confeccionados 9 corpos-de-prova que sofreram um processo de abrasão por escovação e dentifrício, para medir a perda de estrutura em micrômetros, e também a dureza de cada um dos materiais. Os resultados foram analisados permitindo concluir que: 1- a resina composta Z100 tem maior resistência à abrasão e dureza Knoop que a Herculite XRV e 2- observaram ainda uma correlação positiva entre a dureza e a resistência a abrasão.

Neste mesmo contexto, STAHL et al. ${ }^{100}$ (2000) investigaram propriedades flexurais e o comportamento mecânico de três diferentes compósitos em três cores polimerizados com LED ou LH. Os autores buscaram explicar a efetividade do LED comparada ao aparelho de luz LH. Como tal, utilizou-se um aparelho de LH Spectrum LCU modelo 201 R (Dentsply De Trey $\mathrm{GmbH}$, Konstanz, Germany) com fonte de luz de $9 \mathrm{~mm}$ de diâmetro e bulbo halógeno resfriado por ventilador com poder de consumo de $49 \mathrm{~W}$, irradiação de $755 \mathrm{~mW} / \mathrm{cm}^{2}$ e um aparelho tipo LED com 27 feixes (Nichia Chemical Industries Ltd., Anan, Japão) com fonte de luz de $6 \mathrm{~mm}$ de diâmetro com irradiação de $350 \mathrm{~mW} / \mathrm{cm}^{2}$. As resinas usadas foram: Spectrum $\mathrm{TPH}$, cores A2 e A4 
(Dentsply de Trey GmbH, Konstaz, Germany), Z100 cores A2 e A4 (3M/ESPE, St. Paul, MN USA) e Solitare, cores A2 e A3 (Heraeus Kulzer, Wehrheim, Germany). O tempo de ativação foi de 20s para resina Spectrum TPH/A2 e 40s para demais resinas. Os espécimes com dimensões de $25 \mathrm{~mm}$ x $2 \mathrm{~mm}$ x $2 \mathrm{~mm}$ foram armazenados por 24 horas em água antes dos testes, sendo dez para cada cor. A velocidade média do teste foi de $0,75 \mathrm{~mm} / \mathrm{mim}$ até o ponto de fratura do espécime. Os resultados foram analisados com o teste ANOVA a três critérios com 95\% de confiança a fim de identificar os grupos homogêneos. Todos os materiais, exceto a Solitare cor A3, preencheram os requisitos ISO 4049 em termos de resistência flexural, quando polimerizados com LED e LH. Entretanto, a resistência flexural e o comportamento mecânico de todos os espécimes polimerizados com LH foi estatisticamente maior do que os polimerizados com o LED. O potencial de polimerização foi considerado proporcional ao numero de fótons disponíveis para absorção (espectro emitido) e a probabilidade de que estes serão absorvidos (espectro de absorção) considerando também a banda de extensão no espectro para cada aparelho e relacionando com as intensidades de luz. Os autores mencionam que melhor do que somente comparar irradiação dos aparelhos, faltariam mais pesquisas para comparar as propriedade mecânicas das resinas compostas polimerizadas com LED ou LH. 
KURACHI et al. ${ }^{59}$ (2001) realizaram uma pesquisa onde compararam a eficiência de cinco dispositivos experimentais, utilizando 2, 3, 4, 5 ou 6 luzes de emissão por diodo (LED), com uma unidade fotoativadora convencional de luz hológena. Para estimar a capacidade de polimerização de cada fonte de luz, foi usado o teste de dureza Vickers da face não irradiada. Os espécimenes foram preparados com a resina Z-100 (3M/ESPE) na cor A3 e nas dimensões de 0,6mm de diâmetro e espessuras de 0,35, 1,25 e 1,8mm. A lâmpada de luz halógena usada como controle possuía um cabo de fibra que conduzia uma irradiação em torno de $475 \mathrm{~mW} / \mathrm{cm}^{2}$. Neste estudo, a lâmpada de luz halógena usada permitia irradiação por volta de $460 \mathrm{~nm}$ e a LED $470 \mathrm{~nm}$, o que se equipara com o comprimento de onda mais eficiente para ativar a conforoquinona, presente na resina. Mais de $80 \%$ da energia total da lâmpada de luz halógena está além do limite aproveitável para polimerização. A maior parte da energia é removida pela interferência do filtro usado e apenas uma pequena fração de luz efetivamente polimeriza a resina. Em contraste $100 \%$ da luz remanescente emitida pela luz azul LED se encontra dentro do espectro que pode ser usado para polimerizar uma resina. A irradiação da lâmpada de luz halógena se difunde por volta de três vezes mais quando comparada à luz azul emitida pelo LED, o que pode ter um impacto significante na eficiência de polimerização em comparação com a fonte LED. Todos os dispositivos estudados produziram níveis satisfatórios de dureza (acima de 100 unidades de dureza Vickers, VHN) nos espécimes com espessura de 0,35mm. Apesar 
das fontes LED com 3, 4, 5 e 6 lâmpadas terem atingido este valor em menos de 50 segundos, a fonte com 2 lâmpadas necessitou de um tempo de exposição acima de 80 segundos. Os resultados adquiridos neste estudo demonstraram que para os dispositivos de LED avaliados foram necessários tempos de exposição mais longos em comparação com a lâmpada de luz halógena para todas as espessuras de espécimes investigadas. Os autores concluem dizendo que apesar dos dispositivos apresentados neste trabalho ainda não estarem preparados para a utilização clinica, sua eficiência como fonte fotoativadora mostrou ser promissor no futuro como um tipo alternativo de unidade ativadora.

Comparando o grau de conversão com relação ao aumento de temperatura KNEZEVIC et al. ${ }^{58}$ em 2001 , testaram quatro resina composta híbridas (Tetric Ceram, Pertac II, Valuxz Plus e Degufill Mineral) durante exposição à luz convencional halógena dos seguintes aparelhos: Heliolux GTE com $600 \mathrm{~mW} / \mathrm{cm}^{2}$ de intensidade de luz por 40s; Elipar Highlight soft-start (baixa intensidade de luz inicial) com $100 \mathrm{~mW} / \mathrm{cm}^{2}$ por 10 s e com $700 \mathrm{~mW} / \mathrm{cm}^{2}$ por $30 \mathrm{~s}$ e exposição à luz de um conjunto de 16 LEDs de mínima intensidade $\left(12 \mathrm{~mW} / \mathrm{cm}^{2}\right)$. Os autores observaram que o maior grau de conversão foi obtido na resina Pertac II por ambas unidades de luz halógena $(70,39 \pm 1,73$ na superfície, $67,33 \pm 3,14$ em $1 \mathrm{~mm}$ para Heliolux GTE; $68,34 \pm 1,05$ na superfície e $68,45 \pm 1,08$ em $1 \mathrm{~mm}$ de espessura para o Elipar Highlight) e LED $(58,89 \pm$ 1,30 na superfície, $67,33 \pm 3,14$ em $1 \mathrm{~mm}$ de espessura). Perante estes valores, 
os resultados mostraram que a presente diferença no grau de conversão (GC) entre as unidades de luz halógena e a de LED não é tão significante em virtude da considerável diferença de intensidade de luz das mesmas (luz halógena 66 vezes mais potente). Quanto à temperatura, o maior aumento ocorreu com a polimerização de amostras com o Heliolux GTE na superfície e em $1 \mathrm{~mm}$. Menor aumento significativo de temperatura (duas vezes menor) ocorreu na irradiação com o LED comparado com ambas unidades de luz halógena. O aparelho LED mostrou-se uma promissora alternativa para fotopolimerização, principalmente no que se refere ao fator temperatura. Entretanto, para assegurar suficiente intensidade de luz e melhorar os valores de polimerização são necessários o emprego de mais unidades de diodo e a maior concentração do feixe de luz.

Neste mesmo sentido, FRANCO; NAVARRO ${ }^{37}$ (2002) avaliaram a profundidade de polimerização de diferentes resinas compostas, com o mesmo matiz e diferentes cromas, quando polimerizada com LED e LH. Para padronização dos corpos-de-prova utilizou-se uma matriz de aço inoxidável bipartida com $10 \mathrm{~mm}$ de altura e $5 \mathrm{~mm}$ de diâmetro, confeccionando-se cinco espécimes para cada condição experimental. Testou-se um aparelho LED experimental $\left(n^{0} 2\right)$ em comparação aos aparelhos de luz halógena ULTRALUX (Dabi Atlante, Lote 10505) e Curing Light 2500 (3M/ESPE, Lote 3017518) nos tempos de ativação de 20 s e 40 s. A fim de averiguar a intensidade de luz dos aparelhos utilizou-se um radiômetro comercial (Curing Fadiometer Model 
100P/N - 10503/ Demetron Research Corp). Uma faceta de esmalte dentário com espessura de $1,5 \mathrm{~mm}$ foi empregada com a finalidade de avaliar a possível influência na difusão da luz. Imediatamente após a polimerização dos espécimes e remoção da matriz, retirou-se a porção de resina não polimerizada da face oposta à fonte de luz por meio de raspagem com instrumento manual e a mesma foi planificada. Os espécimes foram levados a um dispositivo desenvolvido pelos autores, o qual permite avaliar a resistência à penetração na superfície oposta à fonte de luz. Depois da remoção do espécime do dispositivo, foram realizadas as leituras do material polimerizado com espessímetro. O sistema LED se apresentou viável para polimerização das diferentes resinas, sendo que o tempo de 40 s elevou a profundidade de polimerização das diferentes marcas comerciais para valores próximos aos observados com os aparelhos de LH no tempo de 20s. A interposição da faceta de esmalte reduziu de forma geral a profundidade de polimerização independente, do tipo de fonte de luz. Diante dos menores valores de profundidade de polimerização observados com o LED, um tempo mínimo de 40s deve ser estabelecido para polimerização por meio da estrutura dentária. Não obstante as variações na profundidade de polimerização, os valores apresentados superam a espessura de 1 a $1,5 \mathrm{~mm}$ recomendada na prática clínica tanto para sistema de LH com para o sistema LED. 
DUNN; VUSH ${ }^{27}$ (2002) compararam a dureza de superfície de topo e de base da resina composta híbrida Filtek Z250 na cor A1 (3M/ESPE, USA) e da resina composta de micropartícula Renamel cor A1 (Cosmedent, Chicago), sendo 20 espécimes de cada, feitos em modelos de polímeros de acetato (Delrin, E.I. Dupont de Nemours \& Co., Wilmington, Del.) de $8 \mathrm{~mm} \times 2 \mathrm{~mm}$, polimerizando-os com duas unidades de LH Optilux $400\left(900 \mathrm{~mW} / \mathrm{cm}^{2}\right)$ e Optilux 501 (1030mW/cm² - Demetron Research Corp., Danbury, Conn.) e dois aparelhos LED disponíveis comercialmente (LumaCure $150 \mathrm{~mW} / \mathrm{cm}^{2}$, LumaLite Inc., Sring Valley, Calif.; VersaLux $150 \mathrm{~mW} / \mathrm{cm}^{2}$, Centrix, Shelton, Conn.) com sete LEDs cada. As intensidades de luz dos aparelhos foram checadas prévia e durante o experimento com radiômetro comercial (Demetron 100, Demtron Research Corp.) A duração de exposição foi de 40 s e após $24 \mathrm{~h}$ o teste de dureza por indentação com Knoop (M-400-G2, LECO, St. Joseph, Mich.) foi efetuado com carga de $100 \mathrm{~g}$ e $10 \mathrm{~s}$ de espera com três repetições em superfície de topo e de base seguido do cálculo das médias. Para o cálculo de profundidade de polimerização dividiu-se a dureza da base pela do topo e multiplicou-se o resultado por 100. Usou-se o teste variância ANOVA a dois critérios foi aplicado para determinar diferenças de dureza de superfície com respeito ao tipo de luz, tipo de resina composta e a interação entre os grupos. Quando se compararam os tipos de resina composta as diferenças foram 
significantes, sendo que a resina híbrida apresentou maior dureza de superfície de topo e de base para todos os aparelhos. As unidades de LH produziram maior dureza de superfície de topo e de base do que os LEDs. Comparando-se todas as combinações de tipo de resina e luz, detectaram-se diferenças significantes para todas as superfícies mas não para todas porcentagens de profundidade de polimerização. Ou seja, apesar dos valores de dureza de superfície para ambos os tipos de resina serem inferiores para LED em relação à LH, os resultados da porcentagem de profundidade de cura sozinhos não foram capazes de identificar isto. Finalmente, os autores apontam que a intensidade de luz dos aparelhos tipo LED deve ser aumentada e sugerem estudos que possam comparar grau de conversão, propriedades físicas e mecânicas das resinas após polimerização com estes aparelhos.

Em um trabalho desenvolvido por JANA; SANTOS; CORRÊA ${ }^{49}$ em 2002, os autores compararam a eficiência da fotoativação com LED em relação aos aparelhos de LH por meio de valores de resistência flexural. Foram preparados 10 corpos-de-prova em forma de barra (ISO 4049) em matriz de aço inoxidável, com as resinas Z250 (3M/ESPE), A110 (3M/ESPE), Tetric Ceram TC (Vivadent), Solitaire ST (Heraeus/Kulzer), Durafill DF (Heraeus/Kulzer), EsthetX/ EX, (Dentsply) Definite DT (Degussa) na cor A2. A fotoativação com LED (Ultrablue, DMC equipamentos) e com luz halógena (Optilux 401 Demetron) foi executada por 40 s com uma densidade de potência de $400 \mathrm{~mW} / \mathrm{cm}^{2}$ para cada condição experimental. Após a fotoativação, os espécimes foram mantidos em 
água destilada a $37^{\circ} \mathrm{C}$ por $24 \mathrm{~h}$. Realizou-se o teste de flexão em três pontos em máquina universal de teste Instron 4442, com a velocidade de $0,5 \mathrm{~mm} / \mathrm{min}$. Após a ruptura, os valores (Mpa) foram submetidos à análise de variância e teste de Tukey. A resina Z250 obteve os maiores valores para o LED 149 $(12,5)$ e LH 145 (11,2). Para TC, EX, ST, DF, A10 e DT, não houve diferença estatística entre as médias obtidas com o aparelho de LH e LED. Porém, quando ativada por LED a Definite mostrou menor resistência. As resinas A110 e Durafill obtiveram os menores valores. Concluindo-se que, para as resinas testadas a fotoativação com LED foi tão eficiente quanto a com LH.

PIMENTEL et al. ${ }^{85}$ (2002) ao testar a espessura de resina polimerizada (Filtek Z250) pelo aparelho de LH Optilux/Demetron e pelo LED-Ultrablue/DMC, usaram tempos de 20 s e 40 s em incremento único, sendo que os corpos-deprova foram confeccionados em matriz de aço com $3 \mathrm{~mm}$ de diâmetro e $6 \mathrm{~mm}$ de espessura. Foram confeccionados vinte espécimes (cinco para cada combinação de tempo e aparelhos) e para cada amostra, calculou-se a média de quatro aferições com micrômetro (Starrett/Brasil $n^{0} 436-25 m m$ ). O aparelho de LH apresentou melhor penetração de luz do que o LED, independente do tempo, na espessura de $6 \mathrm{~mm}$.

FAY; LU; POWERS ${ }^{32}$ (2002) avaliaram propriedades mecânicas de uma resina composta e um agente adesivo polimerizado com LED (Elipar FreeLight 3M/ESPE) e com LH (Elipar TriLight - 3M/ESPE). As resinas foram Filtek ${ }^{\text {TM }}$ 
Z-250 (3M/ESPE) e Single Bond (3M/ESPE). Avaliou-se a resistência flexural (RF) e o módulo de flexão em espécimes com dimensões de $2 \mathrm{~mm} \times 2 \mathrm{~mm} \times$ $25 \mathrm{~mm}$ após polimerização por intervalos de 20 s por lado. Da mesma forma a resistência à compressão $(\mathrm{RC})$ e módulo de compressão $(\mathrm{MC})$ foram avaliados em espécimes com dimensões de $4 \mathrm{~mm}$ x 8mm após polimerização por 20 s por lado. Utilizou-se a máquina Instron, com velocidade média de $0,5 \mathrm{~mm} / \mathrm{mim}$, para execução do teste. Também se aferiu a profundidade de cura com espécimes de 0,5 a $5 \mathrm{~mm}$ de espessura polimerizados por $20 \mathrm{~s}$, por meio de medidas de dureza Barcol. Não se observou diferenças significativas nas propriedades dos espécimes obtidos com os diferentes aparelhos. Concluiu-se que a resina composta polimerizada com LED e LH apresentou as mesmas propriedades.

Em um artigo publicado por SANTOS; SILVA E SOUZA JR; MONDELLI $^{94}$ em 2002, sobre novos conceitos relacionados à fotopolimerização das resinas compostas, os autores salientam que os compósitos continuam sendo a opção restauradora mais utilizada quando a estética é primordial, apesar do constante aprimoramento ainda apresentar alguns inconvenientes, tais como sensibilidade pós-operatória, desgaste, contração de polimerização e infiltração marginal. Recentemente, novos conceitos relacionados à polimerização, mediante o uso da redução inicial da intensidade de luz, têm resultado em melhor adaptação marginal. Diversos tipos de aparelhos fotoativadores têm sido lançados no mercado com o intuito de permitir diferentes métodos fotoativação. Neste trabalho, os autores apresentam, 
mediante uma revisão de literatura, os principais fatores relacionados à contração de polimerização, tais como intensidade de luz, métodos de fotoativação, fonte de energia e as técnicas disponíveis para minimizar seus efeitos. Os pesquisadores afirmam que nos últimos 30 anos as fontes luminosas mais utilizadas para fotoativar resinas compostas foram as de luz ultravioleta e de luz halógena. A lâmpada de luz halógena (quartzo tungstênio halogênio - QTH) tem sido a fonte mais utilizada, sendo a maior parte da energia luminosa produzida a de raios infravermelhos (95\%), que são responsáveis pela produção de calor. Para reduzir os raios indesejáveis, são utilizados filtros nos aparelhos, a fim de que os raios produzidos fiquem restritos à faixa de luz visível (5\%), com o comprimento de onda entre 400 a 500nm responsável pela ativação da canforoquinona (CQ). Mais recentemente, surgiram novos aparelhos fotoativadores com outros tipos de fontes de luz, como a de arco de plasma de xenônio, de alto potencial elétrico (2400 $\mathrm{mW} / \mathrm{cm}^{2}$, numa faixa de 450 a $500 \mathrm{~nm}$ ), cujo espectro de energia é mais amplo, incluindo a geração de raios infravermelhos, ultravioleta e luz visível. Outro tipo de fonte usada é a de laser de argônio, que produz fótons que permanecem sempre na mesma freqüência e não divergem, o que permite grande concentração de energia numa pequena área, tem baixa capacidade de produzir raios infravermelhos, o que gera menos calor para o dente. Com essa diversidade de fontes geradoras de energia, torna-se necessário que os fabricantes informem o tipo de fonte de luz, a faixa do espectro do comprimento 
de onda e os ciclos de polimerização oferecidos pelos aparelhos, acontecendo o mesmo com as resinas compostas, pois apesar da canforoquinona ser o fotoiniciador mais comum, outros tipos podem ser utilizados e podem não corresponder ao mesmo espectro de onda oferecido pelo aparelho. Outro tópico abordado refere-se à quantidade de energia necessária para fotoativar a resina composta, pois já se comprovou que diferentes marcas de resina composta necessitam de valores distintos de energia para obter a sua polimerização ideal, obtendo-se assim ótima taxa de conversão, fator importante para as propriedades finais da restauração. Para o calculo da energia deve-se multiplicar a potência da fonte de luz $\left(\mathrm{mW} / \mathrm{cm}^{2}\right)$ pela duração do tempo de exposição, em segundos, sendo expressa em Joules $/ \mathrm{cm}^{2}\left(\mathrm{~J} / \mathrm{cm}^{2}\right)$. Os autores ainda sugerem que as resinas compostas passem a apresentar rotineiramente em suas embalagens a energia ideal para a sua fotoativação, bem como a faixa do comprimento de onda necessária para ativar o iniciador.

Além dessas informações, torna-se importante o conhecimento por parte do cirurgião dentista do grau de conversão monomérica dos compósitos odontológicos e seus possíveis efeitos clínicos, quando polimerizados com diferentes fontes de luz. Por tal razão, KALIX et al. ${ }^{55}$ (2003) avaliaram in vitro os efeitos de duas fontes de luz para polimerização, no grau de conversão monomérica de um compósito de alta densidade (SureFil). Foram 
confeccionados 10 corpos-de-prova a partir de uma matriz metálica (diâmetro = 10,0mm; altura $=2,0 \mathrm{~mm})$, onde o compósito foi inserido em incremento único e dividido em dois grupos. G1: amostras polimerizadas utilizando-se luz halógena convencional com intensidade de $530 \mathrm{~mW} / \mathrm{cm}^{2}$ (Optilux 400 Demetron). G2: amostras polimerizadas utilizando-se LED, com $400 \mathrm{~mW} / \mathrm{cm}^{2}$ de intensidade e comprimento de onda de 440 e 490nm (3M/ESPE Elipar-FreeLight). Ambos grupos foram polimerizados por 40s. Todas as amostras foram armazenadas e mantidas ao abrigo de luz por 24h, em estufa de esterilização e secagem, com temperatura calibrada em $37 \pm 2^{\circ} \mathrm{C}$. A superfície inferior de cada amostra foi desgastada a fim de se obter 1,5 a $2,0 \mathrm{mg}$ de pó. Ao pó do compósito polimerizado foi misturado $70 \mathrm{mg}$ de pó de $\mathrm{KBr}$ (Brometo de Potássio), que posteriormente foi prensado sob a forma de pastilha. O espectro foi por EIVF (Espectroscopia por Infravermelho de Fourier - FTIR), com 40 varreduras, no comprimento de onda na faixa de 400 a $4.000 \mathrm{~cm}^{-1}$ e $2 \mathrm{~cm}^{-1}$ de resolução. As absorções selecionadas para o cálculo do grau de conversão foram 1,610 e $1,637 \mathrm{~cm}^{-1}$ e $2 \mathrm{~cm}^{-1}$. Os resultados dos grupos 1 e 2 foram $41,06 \pm 3,12 \mathrm{mg} \mathrm{e}$ $36,62 \pm 3,07 \mathrm{mg}$ respectivamente. O teste ANOVA mostrou não haver diferença significante entre os grupos testados $(p<5 \%)$. Como tal, os autores concluíram que o grau de conversão monomérica de um compósito de alta densidade foi semelhante quando ativado por luz halógena convencional ou por LED. 
Neste mesmo ano, FERRAREZI; CEFALY; NAVARRO ${ }^{33}$ avaliaram a efetividade de dois tipos de aparelhos fotopolimerizadores, portadores de lâmpada de halogênio e LED, na polimerização de materiais resinosos. Foram confeccionados 20 corpos-de-prova cilíndricos para cada material testados (Filtek ${ }^{T M} Z-100$, Definite e Dyract). Estes foram divididos em quatro subgrupos, com cinco corpos-de-prova, e com fotopolimerizadores (Curing Light 2500 e Ultraled) durante 40s ou 60s pela superfície. Medidas de microdureza foram realizadas na superfície e na base de cada espécime. Os métodos estatísticos empregados foram análise de variância (ANOVA) e do teste de Tukey. Não houve diferença da microdureza entre as fontes de luz na superfície da Z100 e do Dyract, enquanto que a microdureza da superfície foi significativamente mais baixa quando a Definite foi polimerizada pelo LED ao invés da lâmpada halógena. Contudo, a microdureza da base do Dyract e da Definite foi significantemente mais baixa do que a superfície quando fotopolimerizados com o LED. A microdureza da base da resina Definite polimerizada com lâmpada halógena foi significantemente menor do que na superfície. Os autores deste estudo concluíram que o LED testado não foi capaz de produzir a mesma microdureza dos materiais resinosos em comparação a lâmpada halógena. 
Ainda FIROOZMAND; ARAUJO; BALDUCCI ${ }^{35}$ (2003) tiveram como objetivo verificar a profundidade de polimerização de uma resina composta, fotopolimerizadores com de luz halógena (Optilux e Optilight 600) e de luz emissora de diodo (LED) LEC 470-I, através da mensuração da dureza superficial nos 2, 3 e $4 \mathrm{~mm}$ de profundidade. Utilizou-se uma matriz de aço inoxidável previamente confeccionada para a obtenção dos corpos-de-prova. Estas amostras foram confeccionadas com resina composta Z100 (3M/ESPE) na cor A3, fotopolimerizada por 40 segundos. As amostras foram armazenadas em recipiente envolto com papel de alumínio contendo água destilada à temperatura de $37 \pm 2^{\circ} \mathrm{C}$, por 24 horas. Foram embutidas em resina acrílica a fim de serem corretamente posicionadas no aparelho microdurômetro digital Vickers, modelo FM - Future Tech. Realizado o acabamento e polimento, os blocos de resina foram submetidos ao teste de dureza onde foram realizadas impressões em cada milímetro da superfície do compósito. Os dados foram submetidos ao teste ANOVA e ao teste Tukey (5\%). As melhores condições foram verificadas para o Optilux e as piores para o LEC 470-I, independentemente da profundidade de polimerização. Os aparelhos de luz halógena polimerizaram a resina nos 2, 3 e 4mm, enquanto o aparelho de LED polimerizou o material apenas nos 2 e $3 \mathrm{~mm}$ da amostra. Desta forma, os autores concluíram que as amostras polimerizadas com os aparelhos de luz 
halógena apresentaram dureza superficial maior do que aquelas polimerizadas com o aparelho de LED.

Com o intuito de realizar uma análise comparativa da rugosidade superficial de resina composta ativadas por LED e luz halógena, VELLASCO et al. ${ }^{109}$, em 2003 , avaliaram a influência da fonte de fotoativação, luz halógena (LH) e diodos emissores de luz (LED) na rugosidade superficial de uma resina composta micro-híbrida e uma microparticulada. Para isto, foram confeccionados 48 corpos-de-prova, 24 para cada resina empregada $(n=12)$ : Filtek Z250 (3M/ESPE) e Filtek A110 (3M/ESPE). Matrizes acrílicas medindo $4 \mathrm{~mm}$ de diâmetro e $2 \mathrm{~mm}$ de altura foram preenchidas em um único incremento e polimerizadas com cada um dos métodos testados, por 40 segundos. Foi utilizado o aparelho de luz halógena (Optilux 500 - Demetron, $620 \mathrm{~mW} / \mathrm{cm}^{2}$ ) ou LED (Elipar Free Light - 3M/ESPE). Como tal, os corpos-de-prova confeccionados foram divididos em quatro grupos: I- Z250 polimerizada por LH; II- Z250 polimerizada por LED; III- A110 polimerizada por luz halógena e IVA110 polimerizada por LED. Após a confecção dos espécimes, os mesmos ficaram imersos em saliva artificial até a realização das leituras. Os ensaios da rugosidade superficial foram feitos em um rugosímetro (Surf-Corder - Kozaka Lab, Ltda.), realizando-se três leituras seqüenciais em cada corpo-de-prova para que a média dessas leituras fosse considerada na análise de variância. Os resultados foram: grupos I- $0,0832 \pm 0,0116$; II- 0,0749 $\pm 0,0087$; III- 0,0795 $\pm 0,0070$ e IV- $0,0754 \pm 0,0057$. Pela análise dos resultados os autores 
concluíram que as resinas microparticulada e micro-híbrida, quando ativadas por LED, apresentaram menor rugosidade superficial.

É oportuno salientar que a textura ou rugosidade superficial caracterizase pelas micro-irregularidades geométricas deixadas na superfície do material decorrentes do processo de fabricação ou oriundas da interação com processos de desgaste. Como explica o trabalho de dissertação de $\operatorname{RIOS}^{90}$ (2000), a rugosidade de uma superfície é basicamente quantificada através de parâmetros relacionados à altura (amplitude) e largura (ou espaçamento) das irregularidades. Dentro deste contexto, CARPINETTI et al ${ }^{19}$ do Departamento de Engenharia Mecânica da USP publicaram, em 1996, um trabalho sobre os conceitos e princípios da rugosidade superficial. Os autores afirmaram que a rugosidade influi no comportamento das superfícies em vários aspectos como atrito, ajuste oclusal, desgaste, corrosão, aparência, resistência à fadiga, propriedades óticas, escoamento de fluidos e adesão. Segundo a NBR $6405^{6}$ existem definições importantes referentes à rugosidade, como Superfície Real (superfície que limita um corpo e o separa do meio ambiente); Superfície Geométrica (onde não existem erros de forma e de acabamento); Superfície Efetiva (obtida através de instrumentos analisadores de superfície); Perfil Real (intersecção da superfície real com um plano perpendicular à superfície geométrica), Perfil Geométrico (intersecção da superfície com um plano perpendicular a ela); Perfil Efetivo (intersecção da superfície efetiva com um plano perpendicular à superfície geométrica): Comprimento da amostragem (L- 
comprimento medido na direção geral do perfil, suficiente para a avaliação dos parâmetros de rugosidade); Linha Média (LM- é a linha paralela à direção geral do perfil, no comprimento da amostragem, colocada de tal modo que a soma das áreas superiores, compreendidas entre o perfil efetivo, seja igual à soma das áreas inferiores); Desvio Médio Aritmético (Ra- média dos valores absolutos das ordenadas do perfil efetivo (y) em relação à linha média, em um comprimento de amostragem). Segundo o autor, o parâmetro Ra é utilizado para avaliar a rugosidade superficial dos materiais, principalmente no Brasil, Estados Unidos e Inglaterra.

No estudo da rugosidade de superfícies deve se fazer distinção entre rugosidade e curvatura (forma), por meio da filtração onde há retirada de oscilações de longa distância. Em 1981, LEITÃO; HEGDAHL ${ }^{66}$ apresentaram um estudo onde definiram alguns parâmetros de rugosidade, freqüentemente utilizados em pesquisas odontológicas, e discutiram algumas de suas propriedades. Os autores usaram 25 corpos-de-prova de amálgama polidos, de $5 \mathrm{~mm}$, para explicar e demonstrar a sua teoria. Em geral, uma superfície é considerada rugosa quando caracterizada por protrusões e recessos de grande amplitude em pequenas distâncias. A rugosidade pode ser obtida por meio de dados fornecidos por um apalpador que percorre uma superfície, definindo picos e vales. O valor chamado Ra é calculado dividindo-se, de acordo com uma fórmula matemática, a área de picos e vales pela distância, em linha reta, percorrida pelo apalpador. $\mathrm{O}$ valor Ra freqüentemente também é designado 
CLA. Existem também os parâmetros Rs, designado RMS, Rt, entre outros definidos na literatura. O valor Rs é calculado de maneira semelhante ao Ra, no entanto a área de picos e vales é elevada ao quadrado e depois extrai-se a raiz quadrada, de tal modo que se obtenha valores em módulo. O rugosímetro foi o Perthometer (Perthen Mahr). O valor do cut-off é a filtragem ou filtro, o qual, permite minimizar a ondulação da superfície avaliada. Para os autores os resultados do estudo mostraram que um valor maior de cut-off implicou um aumento no valor da rugosidade. Para eles, o valor de Rt é muito limitado para informar sobre toda superfície, pois fornece apenas a distância máxima entre picos e vales, enquanto o valor de Rs está bastante indicado em superfícies com muitas bolhas. O parâmetro de rugosidade deve ser bem escolhido e o valor de cut-off, selecionado e adequadamente definido, para não confundir rugosidade e curvatura e para que as informações obtidas sejam as mais corretas possíveis. 
3 PROPOSIÇÃO 


\section{PROPOSICEÃO}

O objetivo deste estudo foi avaliar quantitativa e qualitativamente $\mathrm{O}$ desgaste e a rugosidade superficial de uma resina composta, a Filtek ${ }^{\mathrm{TM}} \mathrm{Z}-250$ (3M/ESPE), após escovação simulada, em função de diferentes energias e fontes de luz usadas na polimerização, tendo como hipótese nula que o tipo de fonte de luz e a densidade de potência utilizadas na fotoativação da resina composta proporcionará comportamento mecânico semelhante, frente ao teste de escovação simulada. 
4 MATERIAL E MÉTODOS 


\section{MATERIAL E MÉTODOS}

\subsection{Material empregado}

Para a confecção dos espécimes a serem ensaiados no presente trabalho, foi selecionada uma resina composta fotopolimerizável microhíbrida de alta densidade, Filtek ${ }^{T M}$ Z-250, (3M/ESPE, Saint Paul - MN, USA), da cor $A_{2}$, acondicionada em bisnagas contendo 4,0g. Um total de 10 bisnagas foram utilizadas, lote 3YA, com prazo de validade até o mês de junho de 2006.

Esta resina apresenta matriz orgânica constituída basicamente pelo componente Bis-GMA (bisfenol-glicidil-metacrilato), tradicionalmente referido como "resina de Bowen", em homenagem a seu idealizador ${ }^{14}$, cujo diluente principal é o trietileno-glicol-dimetacrilato (TEGDMA). A carga inorgânica é constituída por zircônia e sílica, totalizando $78 \%$ (em peso) do material, cujas partículas apresentam tamanho médio de 0,6 $\mu \mathrm{m}$. A tabela 1 ilustra a marca comercial, característica, fabricante, número lote e validade da resina usada.

TABELA 1- Apresentação da característica, sistema de ativação, fabricante, número de lote, ano e mês de validade da resina composta utilizada neste estudo

\begin{tabular}{ccccc}
\hline Material & $\begin{array}{c}\text { Categoria e } \\
\text { Cor }\end{array}$ & $\begin{array}{c}\text { Sistema de } \\
\text { ativação }\end{array}$ & $\begin{array}{c}\text { Fabricante e N. } \\
\text { de lote }\end{array}$ & $\begin{array}{c}\text { Ano e mês } \\
\text { de validade }\end{array}$ \\
\hline Z250 & Híbrida - A2 & Fotopolimerizável & 3M/ESPE - 3YA & $2006-6$ \\
\hline
\end{tabular}


A tabela 2 ilustra a composição básica da resina composta utilizada neste estudo com relação ao material, matriz orgânica, carga inorgânica, porcentagem em peso de carga e o tamanho médio das partículas.

TABELA 2 - Composição básica da resina composta empregada

\begin{tabular}{ccccc}
\hline Material & $\begin{array}{c}\text { Matriz } \\
\text { Orgânica }\end{array}$ & $\begin{array}{c}\text { Carga } \\
\text { Inorgânica }\end{array}$ & Peso (\%) & $\begin{array}{c}\text { Tamanho Médio da } \\
\text { Partícula }(\boldsymbol{\mu m})\end{array}$ \\
\hline \multirow{2}{*}{ Z250 } & $\begin{array}{c}\text { Bis-GMA } \\
\text { TEGDMA }\end{array}$ & Zircônio / Sílica & 78 & 0,6 \\
\hline
\end{tabular}

Para a respectiva polimerização, foram selecionados dois aparelhos fotopolimerizadores, o VIP (BISCO Inc., EUA), emissor de luz proveniente de lâmpada halógena, e o Ultrablue IS (fabricado pela DMC Equipamentos, Ltda., SP, Brasil), emissor de luz proveniente de diodo. Atualmente, o primeiro destes aparelhos é referido como do tipo convencional e o segundo é consagrado como do tipo LED, sigla originária do termo inglês Light Emitter Diode. As características de regulagem da densidade de potência de ambos aparelhos podem ser encontradas na tabela 3 . 
TABELA 3 - Características de regulagem da densidade de potência dos aparelhos fotopolimerizadores

\begin{tabular}{|c|c|}
\hline Aparelho & $\begin{array}{l}\text { Densidade de potência } \\
\left(\text { expressa em } \mathrm{mW} / \mathrm{cm}^{2}\right)\end{array}$ \\
\hline VIP & Variável de 100 a 600. \\
\hline Ultrablue IS & Fixa, em 300 ou 600 , por tempo programável. \\
\hline
\end{tabular}

Foram confeccionados 40 corpos-de-prova, distribuídos em quatro grupos, sendo dez para cada técnica de fotoativação. Diferentes intensidades de luz com os dois tipos de aparelhos fotopolimerizadores (VIP / Halógena e Ultrablue IS / LED) foram utilizados neste estudo. O tempo de fotoativação empregado para cada condição experimental foi constante 20s por incremento. Pela análise da tabela 4, pode-se observar a distribuição dos quatros grupos avaliados com suas respectivas energias de ativação e abreviaturas.

TABELA 4 - Distribuição dos grupos testados

\begin{tabular}{ccc}
\hline Grupos & $\begin{array}{c}\text { Aparelho / Luz } \\
\text { Intensidade de luz / Tempo }\end{array}$ & $\begin{array}{c}\text { Energia de } \\
\text { Ativação }\end{array}$ \\
\hline G1 & VIP - Halógena & $6 \mathrm{~J} / \mathrm{cm}^{2}$ \\
& $300 \mathrm{~mW} / \mathrm{cm}^{2} \times 20 \mathrm{~s}$ & \\
G2 & VIP - Halógena & $12 \mathrm{~J} / \mathrm{cm}^{2}$ \\
& $600 \mathrm{~mW} / \mathrm{cm}^{2} \times 20 \mathrm{~s}$ & \\
G3 & Ultrablue IS - LED & $6 \mathrm{~J} / \mathrm{cm}^{2}$ \\
& $300 \mathrm{~mW} / \mathrm{cm}^{2} \times 20 \mathrm{~s}$ & \\
G4 & Ultrablue IS - LED & $12 \mathrm{~J} / \mathrm{cm}^{2}$ \\
\end{tabular}


O procedimento de escovação simulada foi realizado com a escova dental Kolynos (Divisão da Colgate Palmolive do Brasil, Itda, Osasco-SP, Brasil). As escovas utilizadas apresentam cerdas de nylon de pontas arredondadas, com vinte e sete tufos distribuídos paralelamente em três fileiras, oferecendo largura ideal para o desenvolvimento deste estudo.

Foi empregado o dentifrício Colgate MFP (Colgate Palmolive, Co., Osasco-SP), sendo este selecionado em função do consumo em larga escala no comércio nacional ${ }^{82}$. $\mathrm{O}$ creme dental escolhido apresenta como agente abrasivo o carbonato de cálcio e sua composição completa está apresentada na tabela 5.

TABELA 5 - Composição do dentifrício Colgate MFP

\title{
Composição básica do dentifrício Colgate MFP
}

\author{
Monofluorfosfato de Sódio (1500 ppm) \\ Carbonato de Cálcio \\ Lauril Sulfato de Sódio \\ Umectante / Espessante / Aromas / Água
}

Todos os matérias e aparelhos fotopolimerizadores empregados neste estudo estão disponíveis no mercado nacional (Figuras 1,2,3 e 4).

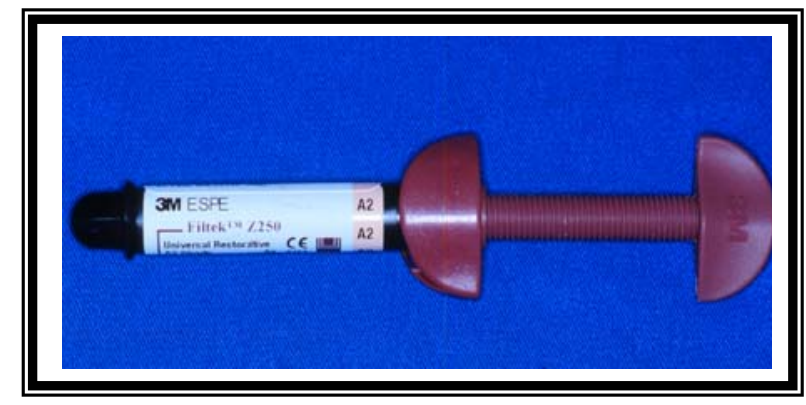

FIGURA 1 - Resina Composta Filtek ${ }^{\mathrm{TM}}$ Z250 (3M/ESPE) 


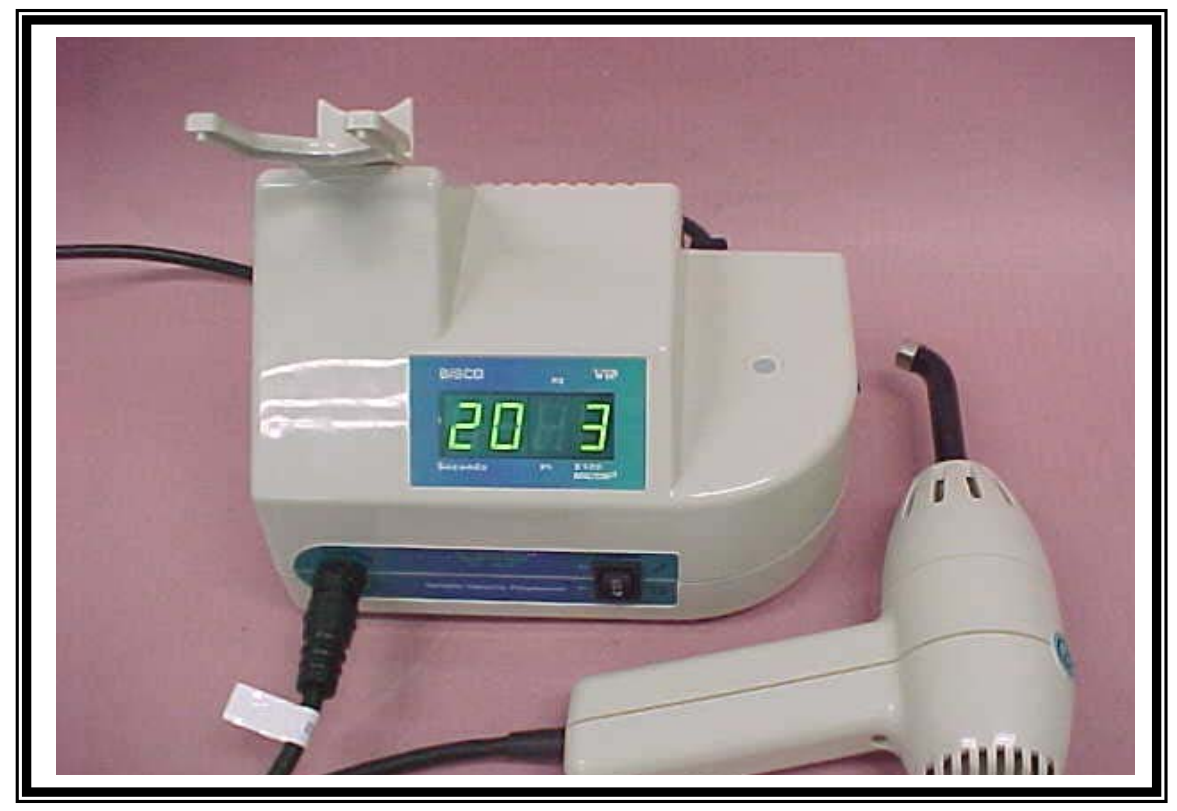

FIGURA 2 - Aparelho VIP (Bisco, inc. USA)

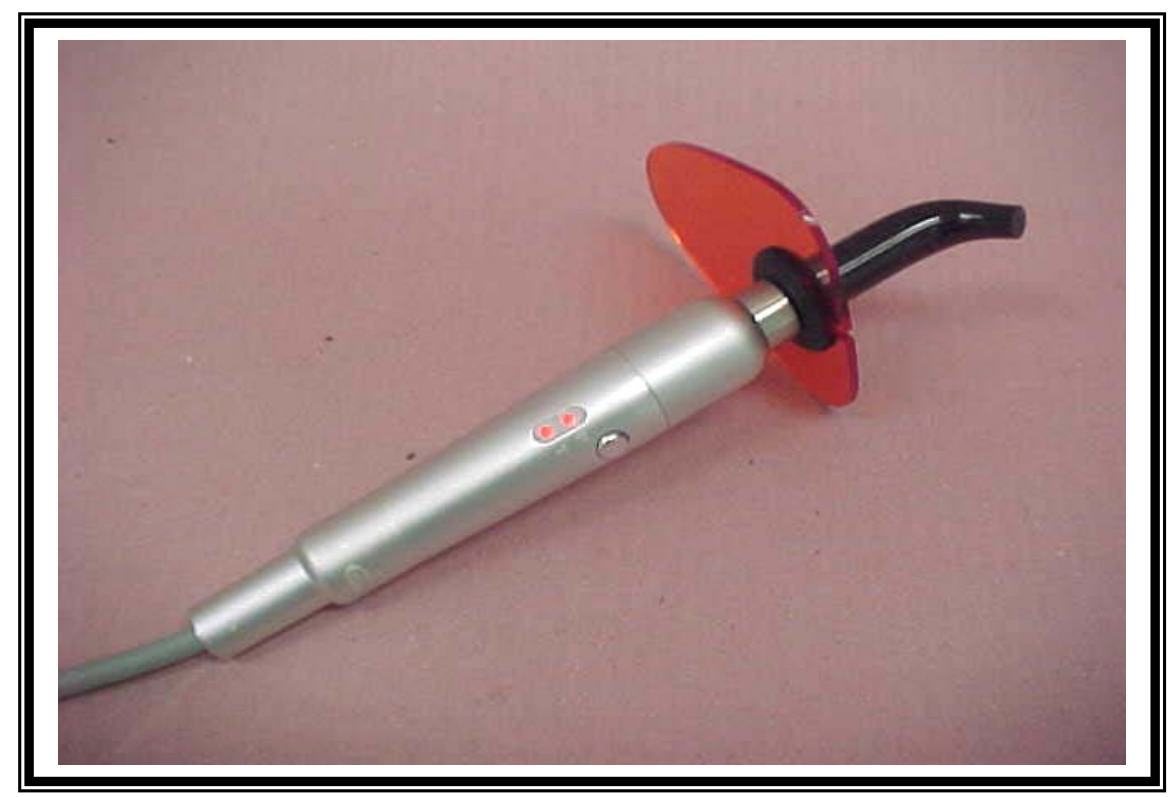

FIGURA 3 - Aparelho Ultrablue IS (DMC Equipamentos) 


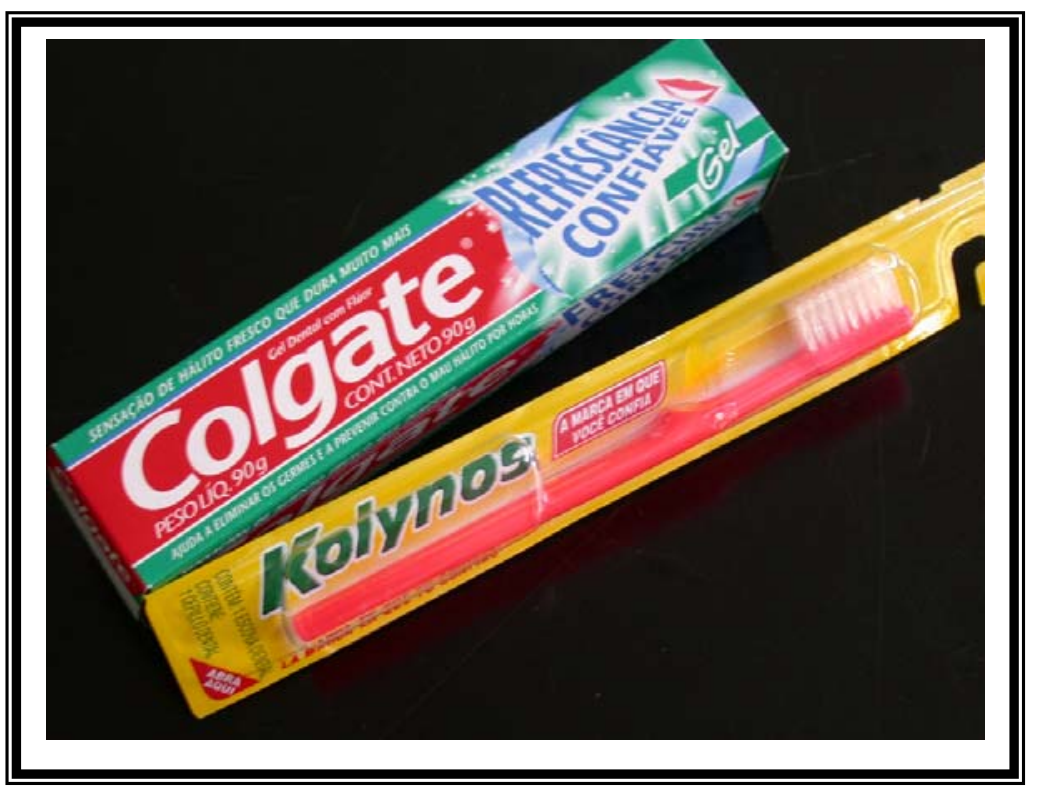

FIGURA 4 - Apresentação comercial do dentifrício e escova dental empregados

\subsection{Obtenção da matriz}

Uma matriz desenhada e fabricada pela escola de Serviço Nacional de Aprendizagem Industrial (SENAI / Bauru) foi desenvolvida especialmente para esta pesquisa. Esta consistiu em uma plataforma de aço inoxidável totalmente plana, com dimensões de $50 \mathrm{~mm} \times 45 \mathrm{~mm} \times 5 \mathrm{~mm}$, possuindo quatro orifícios estrategicamente posicionados (dois na porção central e dois nas porções laterais), possibilitando desta forma, a fixação de dois braços de aço inoxidável com o auxílio de quatro parafusos (Figura 5).

Com a remoção dos parafusos laterais, eram permitidos aos braços livres movimentos de abertura e fechamento, ideais para a inserção e retirada da resina composta, propiciando assim, a obtenção dos corpos-de-prova. Duas linhas de orientação, com $2 \mathrm{~mm}$ de altura, foram colocadas na parte interna de 
cada braço, as quais serviam de guia no momento de aplicar os primeiros incrementos. Uma vez fechados os braços formavam em sua porção central uma cavidade com dimensões internas de $15 \mathrm{~mm}$ de comprimento, $5 \mathrm{~mm}$ de largura e $4 \mathrm{~mm}$ de profundidade, medida exata dos espécimes a serem testados (Figuras 5 e 6$)$.

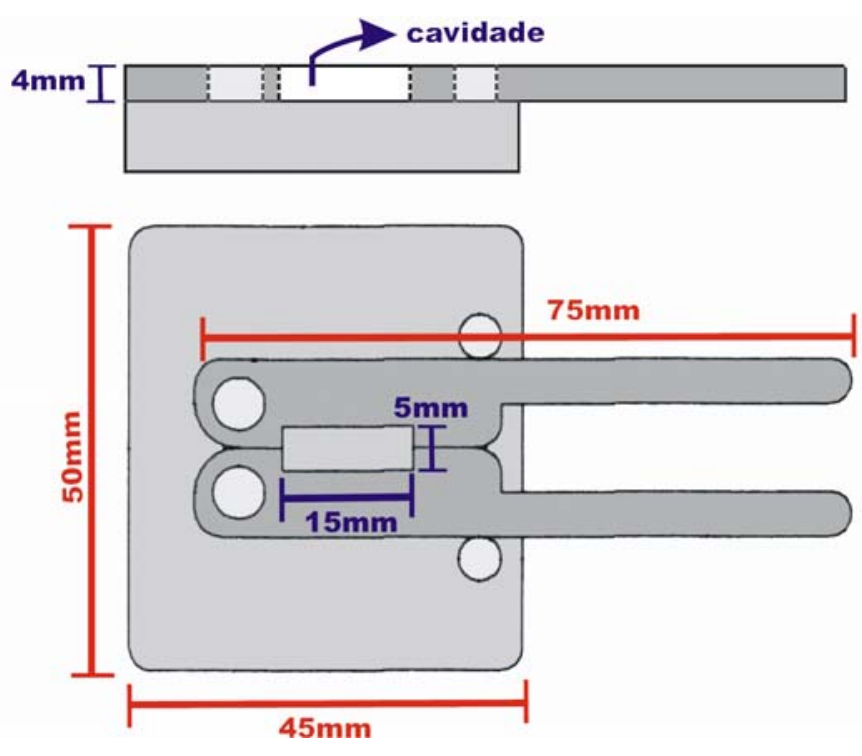

FIGURA 5 - Projeto gráfico e medidas da cavidade, braços e plataforma da matriz empregada

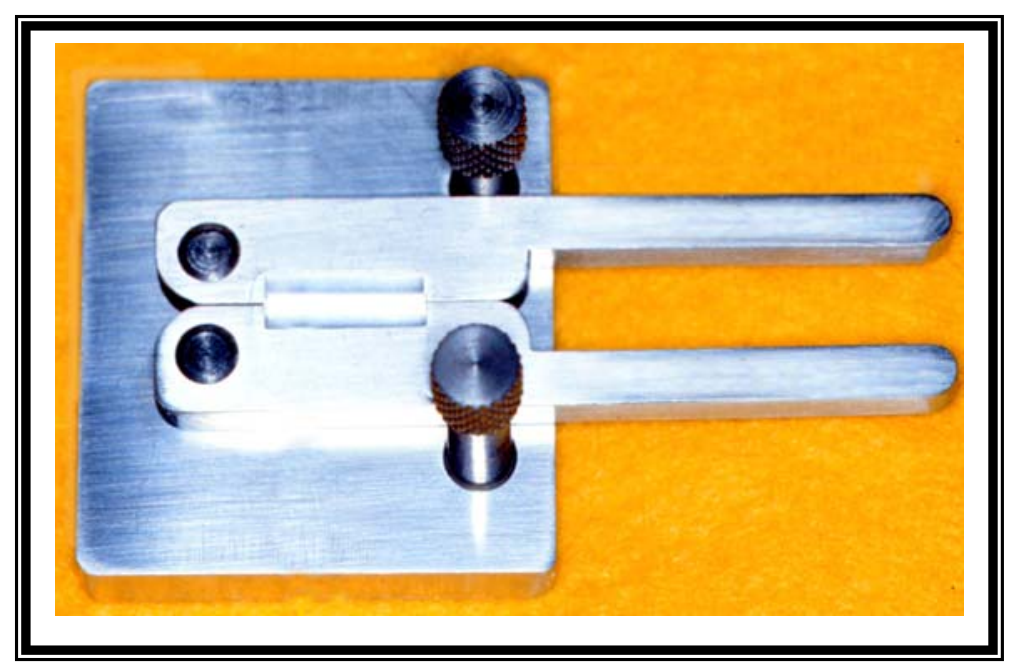

FIGURA 6 - Matriz de aço inoxidável utilizada 


\subsection{Confecção dos corpos-de-prova}

Nesta fase, os procedimentos foram executados em sala especial, de acordo com a especificação 27 da $\mathrm{ADA}^{2,3}$ para restaurações diretas com resina composta, mantendo temperatura de $23 \pm 2^{\circ} \mathrm{C}$, controlada por um termômetro, regulada por condicionador de ar Admiral Royal (Springer Refrigerador AS.,

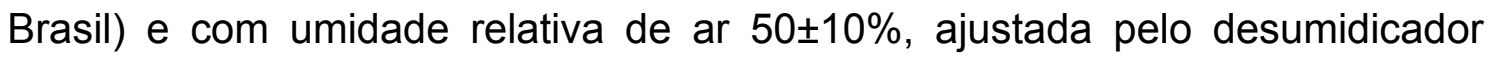
OAS-S, Modelo OD-300 série 1.

Os corpos-de-prova da resina composta foram obtidos a partir da matriz idealizada e confeccionada para a realização deste estudo. Dessa forma, estando a matriz com os braços fechados, foi acomodada na cavidade, com auxilio de uma espátula de inserção apropriada (Hu-Friedy, mini 1 e 3, USA), uma primeira porção da resina composta Filtek ${ }^{T M}$ Z-250 (3M/ESPE, USA) com $2 \mathrm{~mm}$ espessura e $7,5 \mathrm{~mm}$ de comprimento (Figura $7 \mathrm{~A}$ ).

Das dimensões totais do corpo-de-prova, esta primeira porção representa a metade do comprimento e a metade da altura da cavidade interna dos braços. Após fotoativação desta porção, procedeu-se a aplicação e fotopolimerização seqüencial dos outros três incrementos de mesmas dimensões, até terminar a confecção do corpo-de-prova.

Previamente a fotoativação dos dois últimos incrementos, uma tira de poliéster (TDV Dental Ltda, Santa Catarina) foi posicionada e, sobre esta, um dispositivo de aço inoxidável (tipo carimbo) foi submetido a uma carga axial 
manual contínua por 30 segundos para causar extravasamento do excesso do material. Deve-se salientar que o diâmetro das pontas de fibra ótica dos dois aparelhos fotopolimerizadores testados (VIP, Bisco, Inc., USA e Ultrablue IS, DMC Equipamentos) são de $8 \mathrm{~mm}$, condição favorável no momento da fotoativação do primeiro e dos subseqüentes incrementos (Figura 7).

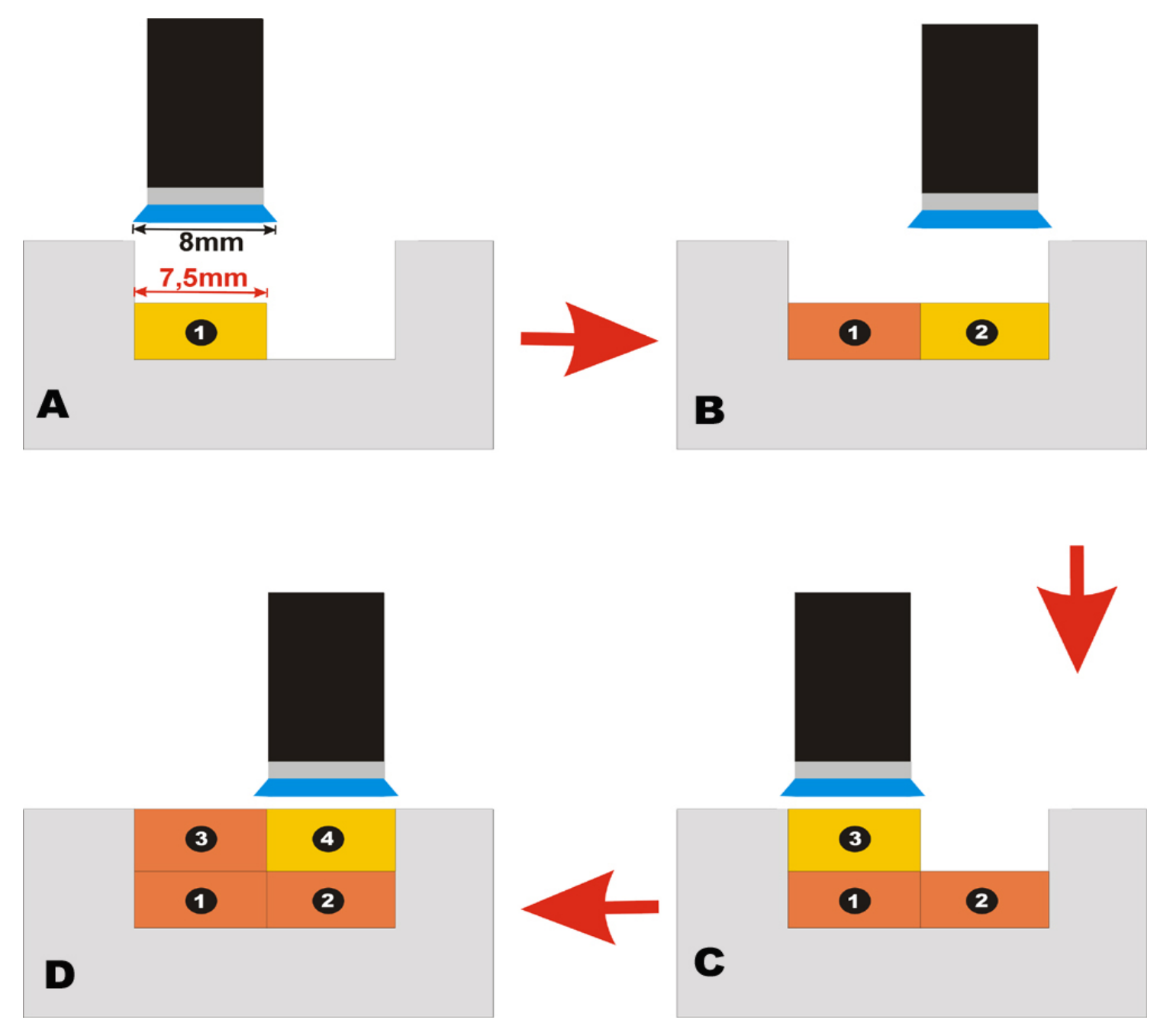

FIGURA 7 - Esquema ilustrativo que evidencia a aplicação dos incrementos para obtenção final dos corpos-de-prova. A: primeiro incremento; B: segundo incremento; C: terceiro incremento e $\mathrm{D}$ : quarto incremento 
ressalta-se que nenhum anteparo foi utilizado após a polimerização do primeiro incremento de resina com a finalidade de protegê-lo de uma eventual sobre-polimerização. Entretanto, esta limitação não invalida a metodologia empregada, pois somente o último incremento foi avaliado frente ao teste de escovação sumulada.

Como tal, foram obtidos quarenta corpos de prova, dez para cada condição experimental (HT, HS, LT e LS x 20s). A intensidade de luz dos aparelhos era freqüentemente aferida e controlada por um radiômetro ${ }^{22,90,112}$ (Curing Radiômetro: Model 100 P/N-10503 / Demetron Reserch Corp.), permanecendo na faixa de 300 e $600 \mathrm{~mW} / \mathrm{cm}^{2}$.

\subsection{Planificação dos corpos-de-prova}

Nesta etapa, os espécimes foram fixados com cera pegajosa Kota (Kota Ind. e Com. Ltda., São Paulo, SP), com o auxílio de um instrumento de PKT (Duflex Ind. Bras.) e uma lamparina (JON, Ind. Bras.), no centro de um disco de acrílico (30mm de diâmetro por $8 \mathrm{~mm}$ de espessura), com a face inferior da resina composta voltada para o disco, com o intuito de realizar a planificação da área estudada.

Para isso, o conjunto (corpo-de-prova/disco) foi adaptado em uma Politriz Metalográfica (APL 4, Arotec, Cotia, SP), com sistema de polimento múltiplo, capaz de realizar o polimento automático de 6 corpos-de-prova, 
permitindo o paralelismo entre as superfícies polidas e a base de acrílico onde foram fixados os corpos-de-prova (Figura 8).

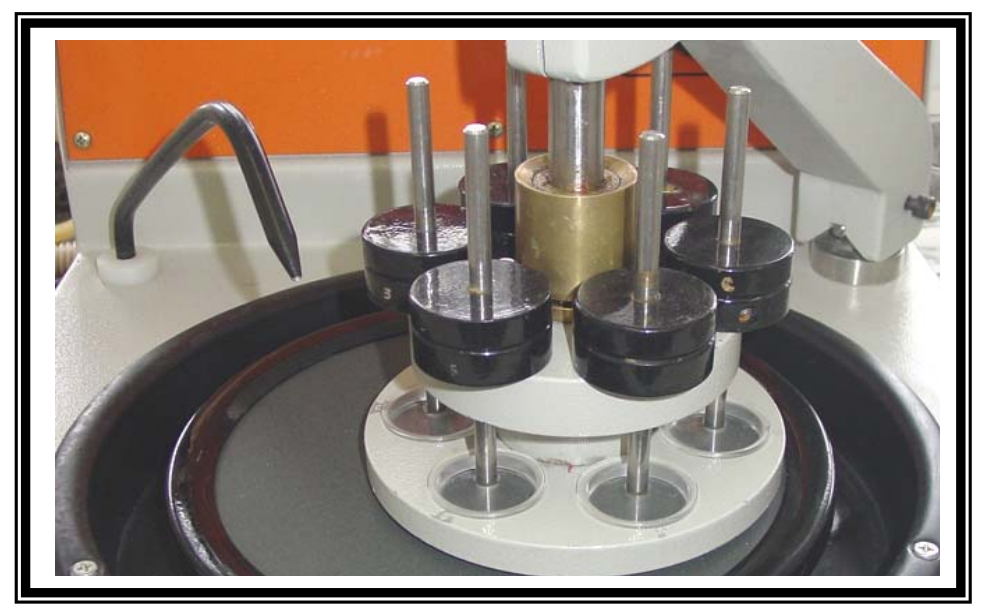

FIGURA 8 - Politriz Metalográfica

Para a planificação da superfície a ser avaliada, foram utilizadas em ordem ascendente quatro lixas de silicone carbide de granulométria 300,600, 800, 1200 (Extec Corp.), com refrigeração de água deionizada, até que os corpos-de-prova ficassem com espessura aproximada de $3 \mathrm{~mm}$. Para tanto, a politriz foi acionada em baixa velocidade, com peso padrão de $172 \mathrm{~g}$, durante 1 minuto, até se alcançar à espessura desejada.

Com o propósito de finalizar o polimento, foi utilizado um feltro (Extec Corp.) umedecido com suspensão de diamante de $1 \mu \mathrm{m}$ (Buehler), durante 2 minutos, com mesmo peso, em velocidade alta, quando se pode observar superfície da resina com aspecto brilhante. Este tratamento teve o objetivo de planificar e remover qualquer tipo de ranhura que pudesse comprometer no 
corpo-de-prova, requisito fundamental na avaliação da rugosidade superficial e do desgaste ${ }^{46}$.

Para impedir que os grãos das primeiras lixas interferissem na qualidade do polimento das seguintes, entre cada etapa de polimento, o conjunto corpode-prova/disco foi levado a um aparelho de ultra-som T7 Thornton (Unique Ind. e Com. de Produtos Eletrônicos Ltda., São Paulo, SP), com freqüência de $40 \mathrm{KHz}$, durante 5 minutos, com água destilada deionizada. Ao final do polimento os espécimes ficaram imersos por 10 minutos em água deionizada corrente.

\subsection{Determinação da rugosidade superficial inicial}

Para realização das leituras de rugosidade superficial (após obtenção dos corpos-de-prova), foi utilizado o rugosímetro Hommel Tester T1000 basic (Hommelwerke GmbH ref. \# 240851 - Schwenningem - Germany) que constitui um aparelho (Figura 9) de alta sensibilidade, com ponta apalpadora de diamante (Figura 10), a qual percorre uma superfície e pode ser acoplado a uma unidade que processa e interage as informações quantitativamente. Desta forma, os resultados são registrados imediatamente e digitalmente em visor de cristal líquido. Para este estudo, o rugosímetro foi conectado a um microcomputador que processava e armazenava todas as informações pertinentes aos ensaios. 


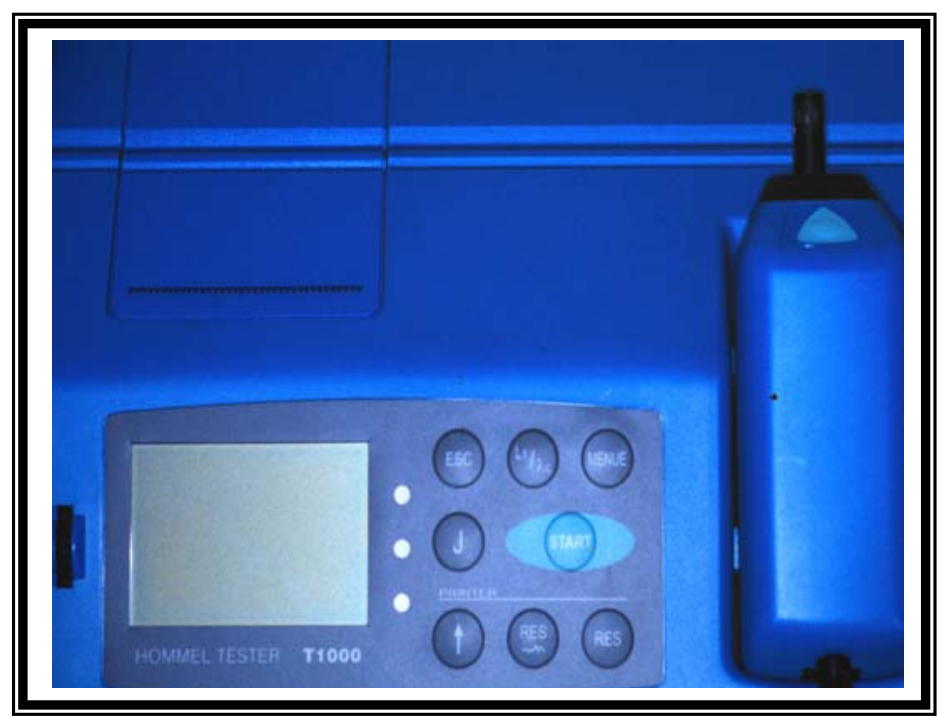

FIGURA 9 - Rugosímetro Hommel Tester T 1000

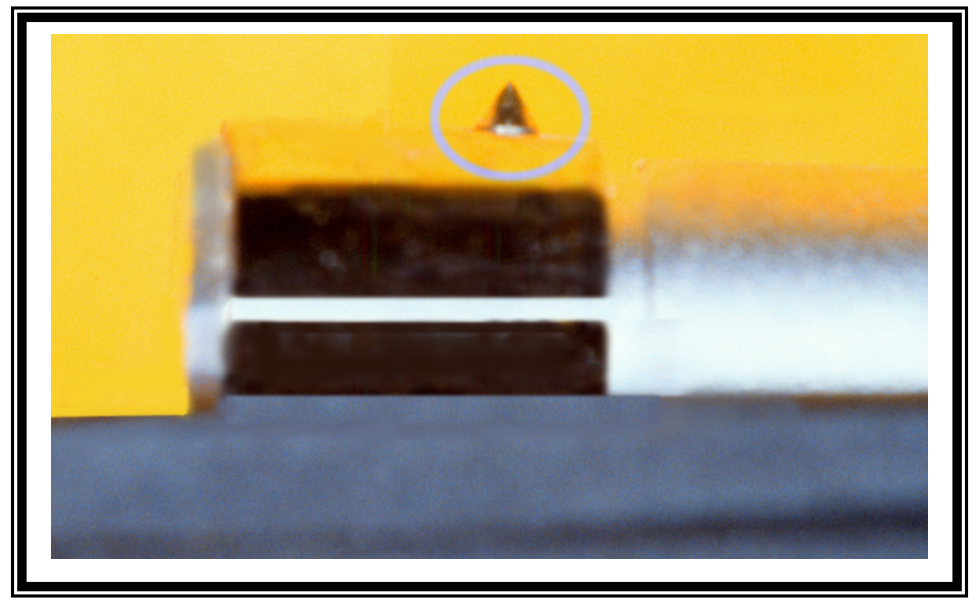

FIGURA 10 - Ponta apalpadora do Rugosímetro Hommel T100 
Deste modo, as leituras iniciais foram tomadas na área teste a ser escovada, no centro da superfície de cada corpo-de-prova, em sentido perpendicular à ação das cerdas, de forma livre e aleatória, totalizando cinco leituras, das quais foi obtida a média considerada como valor inicial ${ }^{46,80,107,112}$. Regiões onde era nítido algum tipo de irregularidade foram desconsideradas, procurando-se áreas visivelmente livres de irregularidades.

O parâmetro utilizado para obtenção da rugosidade superficial foi a rugosidade aritmética $(\mathrm{Ra})$, que traduz o valor da média aritmética de todas as distâncias absolutas do perfil de rugosidade $(R)$ desde a linha central, dentro da extensão de medida (Lm).

Os parâmetros escolhidos para a rugosidade superficial foram:

$$
\begin{aligned}
& \text { T mínima }=0.01 \mu \mathrm{m} \quad \mathrm{Lt}=5 \mathrm{~mm} \quad \mathrm{Lm}=4.5 \mathrm{~mm} \\
& \text { T máxima }=2 \mu \mathrm{m} \quad \mathrm{Lc}=0.25 \mathrm{~mm} \text { (cut-off) } \\
& \text { Sendo: } \\
& \mathrm{T}=\text { tolerância (valores extremos a serem considerados nas leituras) } \\
& \mathrm{Lt}=\text { limite de tracejamento (extensão real percorrida pela ponta ativa) } \\
& \mathrm{Lm}=\text { limite de medição (extensão considerada na leitura) } \\
& \mathrm{Lc}=\text { cut-off (filtragem, minimizando a ondulação da superfície) }
\end{aligned}
$$

\subsection{Armazenamento dos corpos-de-prova}

Após determinação da rugosidade superficial na área teste previamente ao procedimento de abrasão, os quarentas corpos-de-prova foram 
armazenados em recipientes plásticos negros, com $5 \mathrm{ml}$ de água deionizada, hermeticamente fechados, identificados e a temperatura de $37^{\circ} \mathrm{C}$ e umidade absoluta de $100 \%$. Foi aguardado o período de sete dias para a ocorrência de absorção de água e estabilidade da massa ${ }^{1,3,56}$, propriedade característica deste material (resina composta), para então ser realizada a escovação simulada.

\subsection{Procedimento de abrasão}

Para a realização dos testes de abrasão foi utilizada uma máquina para simulação de escovação idealizada para esse propósito (Figura 11), através do protocolo descrito em 2001 por TURSSI ${ }^{104}$ (Figuras 11,12,13 e 14).

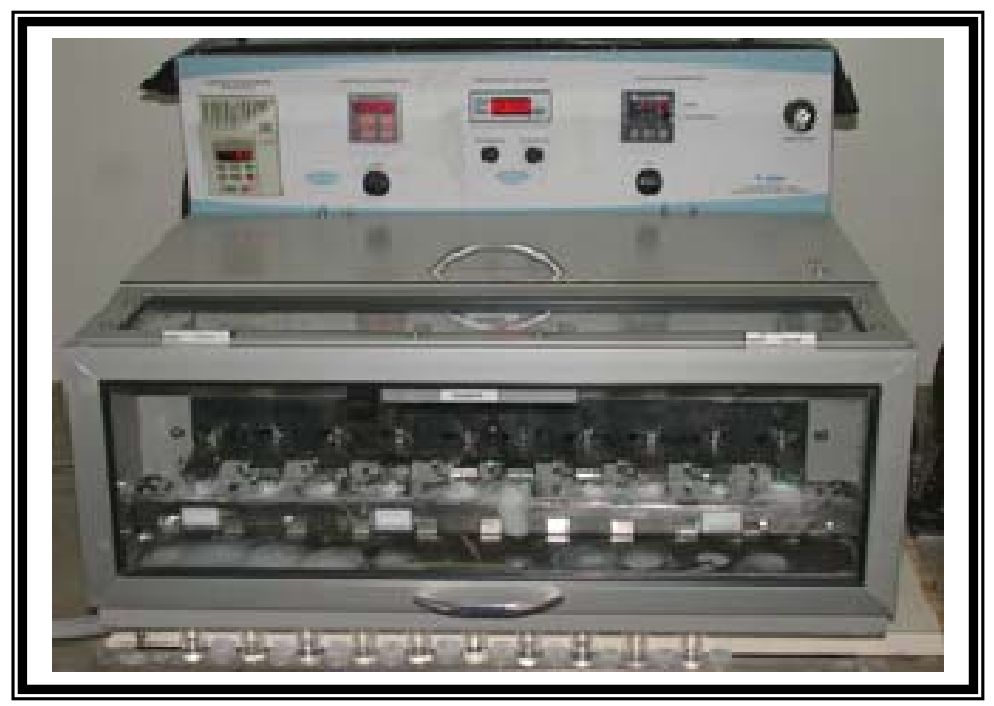

FIGURA 11 - Máquina utilizada nos testes de escovação simulada 


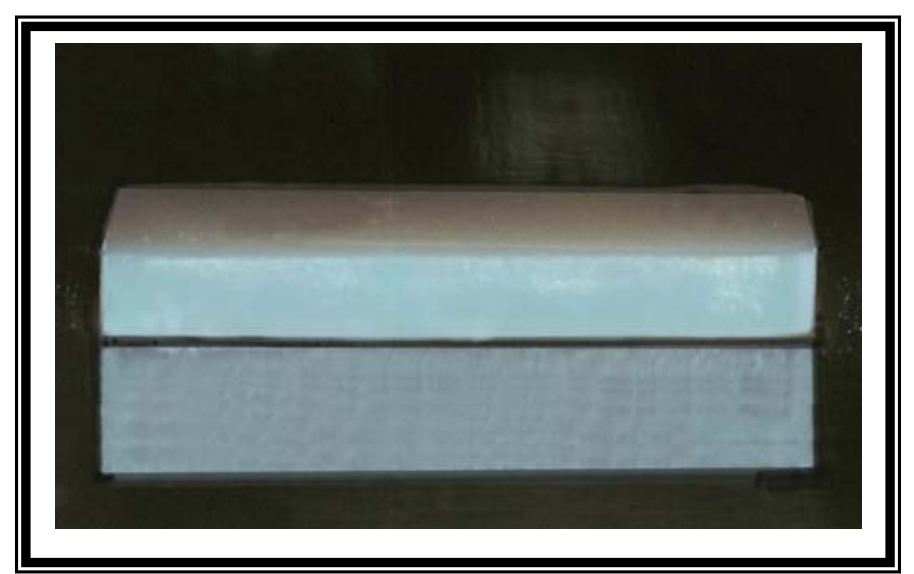

FIGURA 12 - Disposição do espécime na barra metálica do equipamento

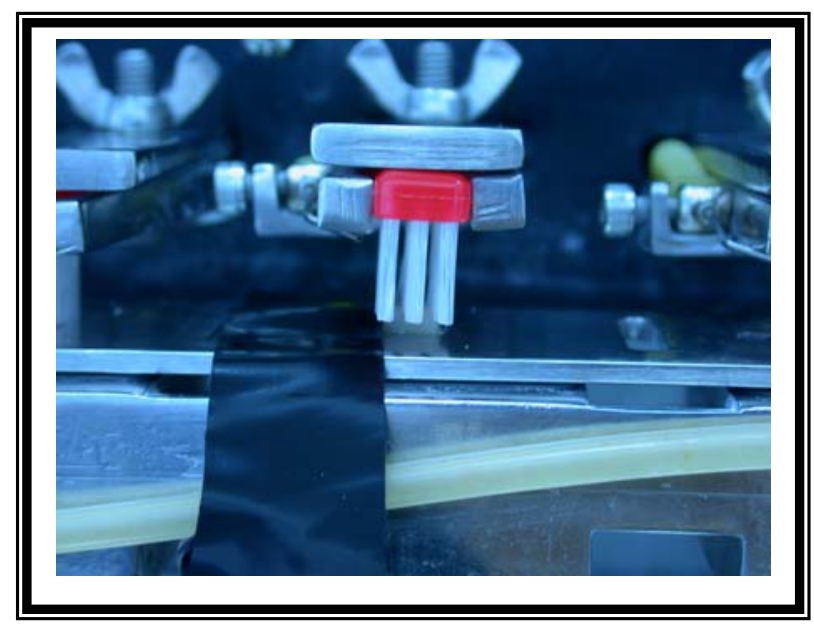

FIGURA 13 - Proteção e disposição do espécime em relação à escova dental 


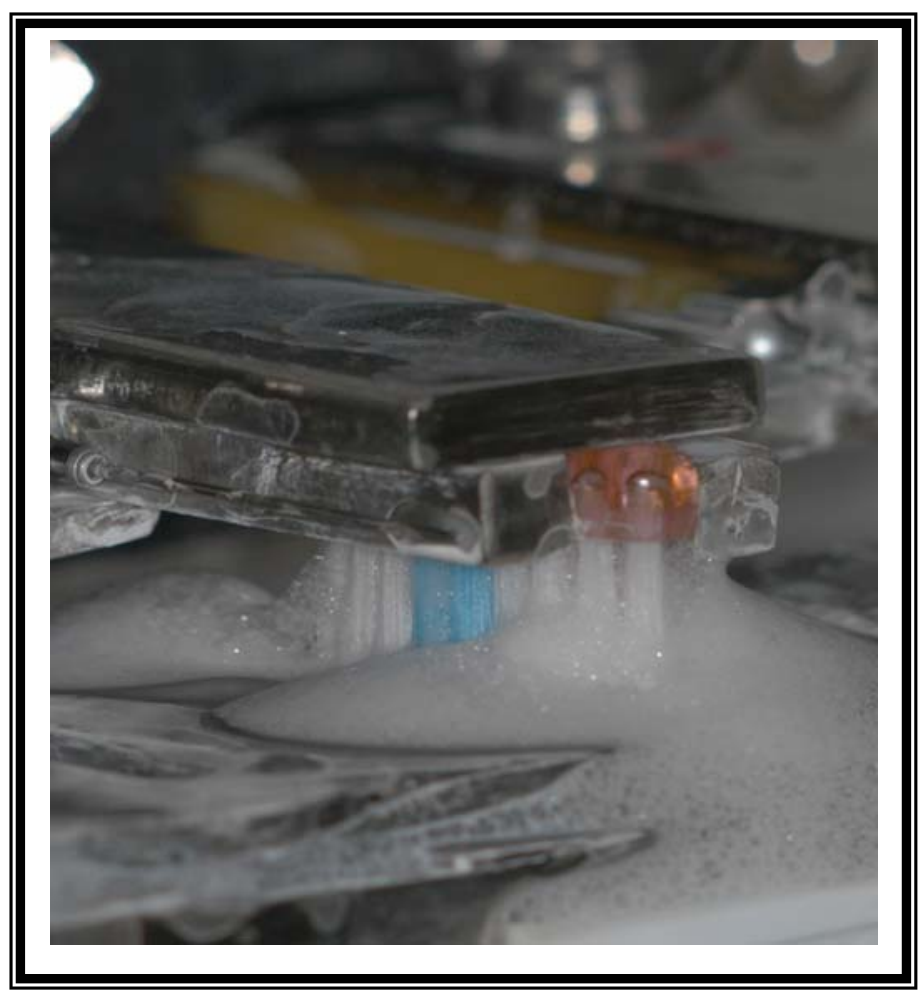

FIGURA 14 - Escovação do espécime

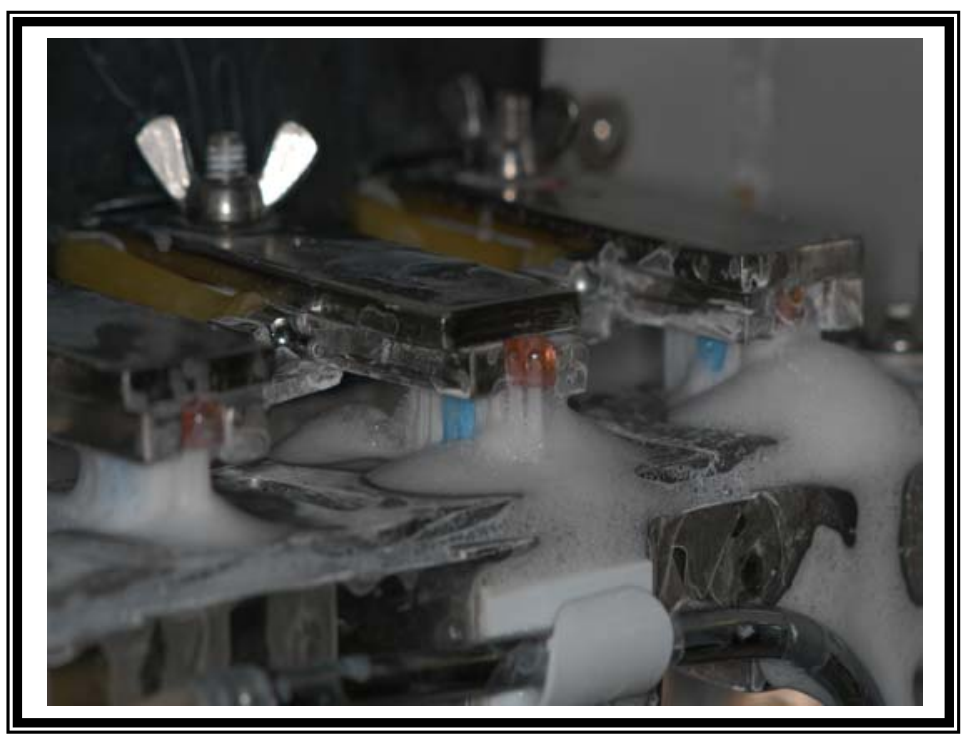

FIGURA 15 - Escovação simultânea dos espécimes 
O equipamento consiste em um motor que produz movimentos de vaivem em dez braços, nos quais são fixados as "cabeças" das escovas dentais (Kolynos), viabilizando a simulação simultânea da escovação em dez corposde-prova. Com o objetivo de impedir a movimentação dos mesmos durante o movimento de vai-vem, o equipamento possui uma barra de aço inoxidável com dez cavidades independentes (15mm de comprimento, 5 de largura e $3 \mathrm{~mm}$ de espessura) para o posicionamento e estabilidade dos espécimes (Figura 12).

Faz-se oportuno salientar que as dimensões de cada corpo-de-prova reproduzia fielmente as dimensões das dez cavidades encontradas na barra de aço inoxidável do equipamento. No entanto, a espessura de $1 \mathrm{~mm}$ a mais no corpo-de-prova garantia um processo de abrasão muito mais efetivo e notável, necessário para as aferições deste estudo.

Em seguida, as cabeças das escovas dentais, $(8 \mathrm{~mm})$ foram colocadas e fixadas paralelamente em metade do corpo-de-prova, área a qual seria submetida aos testes de escovação (lado escovado). Conforme o método proposto, a outra metade (lado controle) do mesmo corpo-de-prova foi protegida com uma fita isolante, permitindo uma clara identificação entre a área escovada e área controle, condição essencial para as futuras mensurações de desgaste. A figura 13 apresenta a disposição e proteção do espécime na barra de aço inoxidável do equipamento com relação ao posicionamento da escova. 
O equipamento é dotado de um sensor de temperatura que viabiliza a escovação a temperatura de $37 \pm 2^{\circ} \mathrm{C}$ por meio de monitoramento preciso e livre de interferências externas. A amplitude da excursão dos movimentos de escovação foi ajustada em $20 \mathrm{~mm}$, compatível com a dimensão lateral dos espécimes. A velocidade foi ajustada em 4,5 ciclos por segundo, com carga de 300g. Durante a escovação, a máquina foi programada para injetar freqüentemente, em cada corpo-de-prova, $0,4 \mathrm{ml}$ da solução a cada dois minutos (Figuras 14 e 15).

A suspensão consistiu de dentifrício dental (Colgate MFP) e água destilada na proporção de 1:2, em peso, e foi pesada e diluída no interior de um Becker com água destilada, de acordo com a especificação ISO ${ }^{47}$. O preparo da solução foi realizado imediatamente antes da sua utilização, com a finalidade de se preservar suas características. Monitorou-se o pH da solução no ato do seu preparo através de um pHâmetro (B 371, MicroNal S.A, São Paulo) sendo registrado um valor de 8,4 , sem variações significantes ${ }^{87,90,112}$. Para o procedimento de escovação em si, os grupos foram escolhidos aleatoriamente e os espécimes cuidadosamente encaixados nos dez orifícios na barra de aço inoxidável do equipamento, com aproximadamente $1 \mathrm{~mm}$ acima desta, garantindo um contato íntimo dos tufos ou fileiras das escovas dentais com cada espécime ${ }^{23,45,90}$. As escovas de dente foram trocadas ao término de cada 50.000 ciclos, em um total de 200.000 ciclos de escovação para cada espécime. O tempo de ensaio para cada grupo (200.000 ciclos), foi de aproximadamente 16 horas. 


\subsection{Limpeza dos corpos-de-prova}

Após o término dos 200.000 ciclos de escovação, os espécimes foram lavados com água corrente com auxílio de uma pinça clínica. Em seguida, foram colocados no interior de um aparelho de vibração ultra-sônica (Tempo Ultrasonic Ind. Com. Ltda, Taboão da Serra - SP, modelo T-14) por 10 minutos, cujo compartimento central continha água destilada para que as partículas abrasivas do creme dental fossem removidas. Imediatamente foram secados com papéis absorventes e armazenados em $5 \mathrm{ml}$ de água destilada no interior dos recipientes individualizados, identificados a uma temperatura de $37^{\circ} \mathrm{C}$ e umidade absoluta de $100 \%{ }^{87}$.

\subsection{Determinação da rugosidade superficial final}

As leituras de rugosidade superficial final foram realizadas exclusivamente na área submetida ao procedimento de abrasão (lado escovado) seguindo-se a mesma metodologia descrita anteriormente no item 4.2.4. As diferenças dos valores entre as médias iniciais e finais foram reportadas como a alteração final da rugosidade (Anexos).

\subsection{Determinação do desgaste}

Para as leituras de desgaste da superfície dos corpos-de-prova foi utilizado o mesmo aparelho, Hommel Tester T1000 basic (Hommelwerke GmbH ref. \# 240851 - Schwenningem - Germany), usado na determinação da 
rugosidade superficial. Porém, para a mensuração dos valores de desgaste, foram utilizados outros parâmetros na programação do aparelho.

O rugosímetro (Figura 9) foi conectado a um microcomputador que processava todas as informações pertinentes aos ensaios. Com o auxílio de um software do equipamento (Turbo Datawin-NT, Versão 1.34, Copyright (C 2001) além dos dados específicos das rugosidades superficiais, foram obtidos também os perfis reais das superfícies testadas, sendo estes importantes para a ilustração e quantificação do desgaste. Foram feitas cinco mensurações para se obter a média do desgaste.

Para padronização efetiva da distância, que precisava ser percorrida pela ponta apalpadora do aparelho, e da programação do mesmo, através do parâmetro Lt (limite do tracejamento), foram feitas duas linhas na lateral dos espécimes, as quais serviram de orientação no posicionamento da ponta apalpadora no início das leituras.

Desta forma, o perfil traçado pelo rugosímetro percorreu a superfície dos corpos-de-prova passando pela metade protegida (lado controle) e pela metade não protegida (lado escovado). Como o lado controle não foi escovado e se assemelhava muito a uma linha reta, tornou-se fácil à identificação da região submetida à escovação (lado escovado). Assim sendo, a perda de resina composta foi quantificada pelo perfil real medindo-se à distância em micrometros $(\mu \mathrm{m})$ da linha média do gráfico, correspondente à linha do plano da área protegida (lado controle) do espécime, até o maior vale correspondente à área escovada ${ }^{46}$ (Figura 16). 


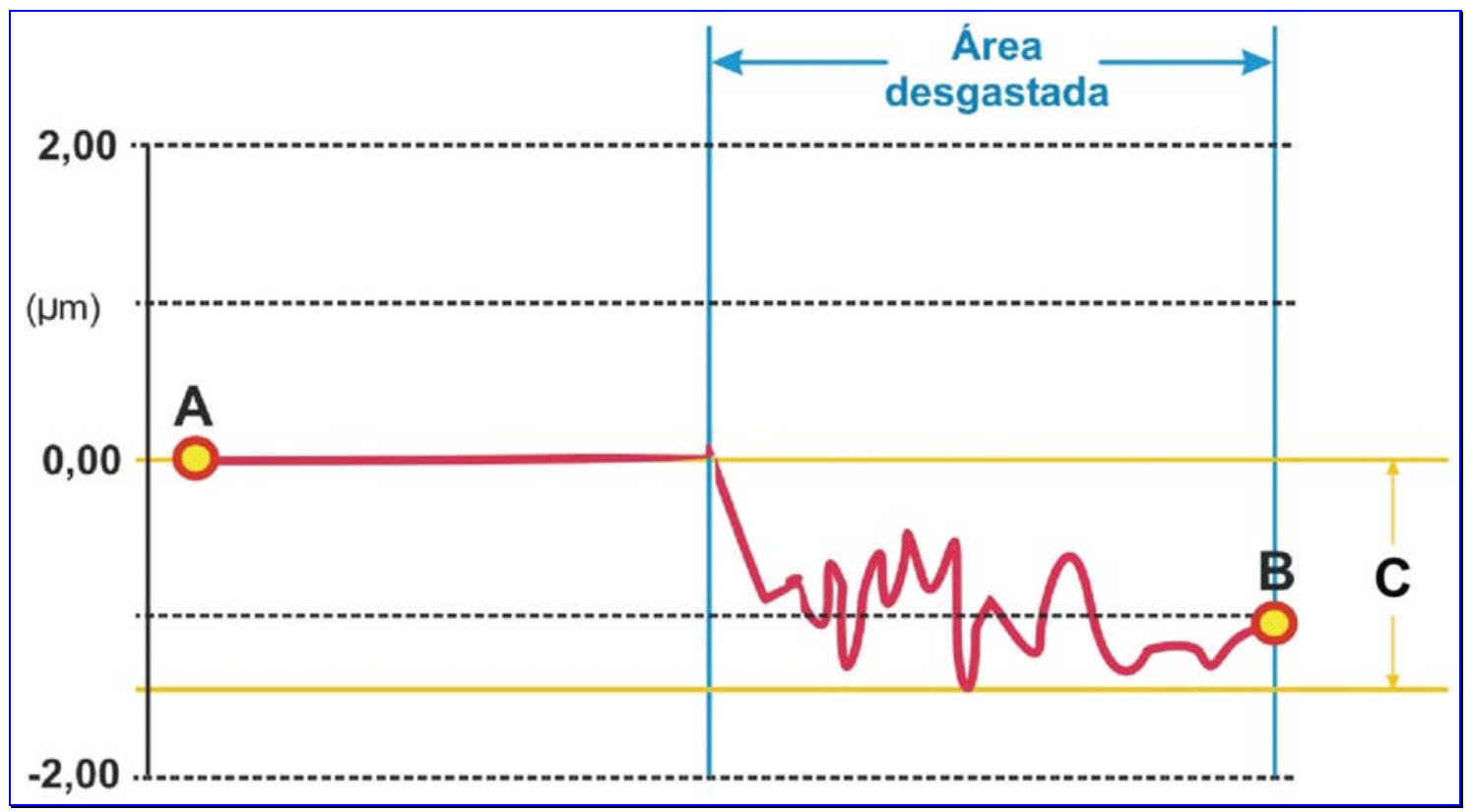

FIGURA 16 - Ilustração esquemática mostrando o desgaste dos espécimes testados. (A) início da leitura feita pelo rugosímetro; (B) final da leitura e $\mathrm{C}$ desgaste máximo ocasionado pelo procedimento de abrasão

Para aferição do desgaste através do perfil real da superfície de cada copo de prova foram escolhidos os seguintes parâmetros:

$$
\begin{array}{ll}
\text { T mínima }=8 \mu \mathrm{m} & \mathrm{Lt}=10 \mathrm{~mm} \quad \mathrm{Lm}=9 \mathrm{~mm} \\
\text { T máxima }=40 \mu \mathrm{m} & \mathrm{Lc}=0.00 \mathrm{~mm} \text { (cut-off) } \\
\text { Sendo: } &
\end{array}
$$

T= tolerância (valores extremos a serem considerados nas leituras)

$\mathrm{Lt}=$ limite de tracejamento (extensão real percorrida pela ponta ativa)

Lm= limite de medição (extensão considerada na leitura)

Lc= cut-off (filtragem, minimizando a ondulação da superfície) 


\subsection{Observação em microscopia eletrônica de varredura}

Este procedimento foi realizado com finalidade ilustrativa. A Escola Superior de Agricultura "Luiz de Queiroz", especialmente o Núcleo de Apoio à Pesquisa / Microscopia Eletrônica Aplicada à Pesquisa Agropecuária da Universidade de São Paulo / Piracicaba (NAP/MEPA - ESALQ/USP) tornou-se fundamental para finalização desta etapa.

Para tal, um espécime de cada grupo foi aleatoriamente selecionado e posteriormente fixado em base de latão com esmalte de unha (Rique, Niasi,Taboão da Serra) e metalizados (Hammer VI-sputtering sytem - Ana tech Ltd, Alexandria, U.S.A.) com partículas de ouro, possibilitando o registro das fotomicrografias através do microscópio eletrônico de varredura de pressão variável (MEV LEO 435 VP, Cliffon Road Cambridge CB13QH, England) em aumento de 42x,150x e1500x.

\subsection{Análise estatística}

Os resultados foram submetidos à analise estatística para a verificação de diferenças ou não entre os grupos, em relação ao desgaste e rugosidade superficial da resina composta testada, utilizando um programa estatístico versão 5.0. Os resultados foram submetidos ao teste ANOVA (análise de variância) a dois critérios de classificação (tipo de aparelhos e diferentes densidade de potência), análise de correlação de Pearson e o teste de Tukey, 
que foi utilizado para comparações individuais entre os grupos. Para ambos os testes o nível de significância empregado foi de 5\%, com $p<0,05$. 


\section{RESULTADOS}

\subsection{Desgaste}

A determinação do desgaste foi verificada pela média de cinco leituras dos perfis reais das superfícies de cada corpo-de-prova obtidos por meio do rugosímetro. Com intuito de possibilitar a realização dos ensaios de desgaste, foi necessário o polimento com a politriz metalográfica (Figura 8), das áreas a serem mensuradas. O objetivo foi obter um perfil o mais próximo possível de uma linha reta. Passando pela metade protegida (lado controle) e pela metade não protegida (lado escovado), a ponta apalpadora do rugosímetro foi programada para realizar um percurso de $10 \mathrm{~mm}$ ( $\mathrm{Lt}=$ limite de tracejamento), com escala de $100 \mu \mathrm{m}$. Não foi utilizada a filtragem ou minimização das ondas da superfície (cut off / Lc=0.00mm).

Desta forma, como o perfil do lado controle sempre se assemelhará a uma linha reta, pelo fato de estar protegido e não ter sido escovado, toda alteração visualizada seria resultado do processo de escovação a qual os espécimes foram submetidos (lado escovado). Assim sendo, pode-se visualizar e mensurar o desgaste dos corpos-de-prova dos 4 grupos testados (Figuras 17, 18,19 e 20). 


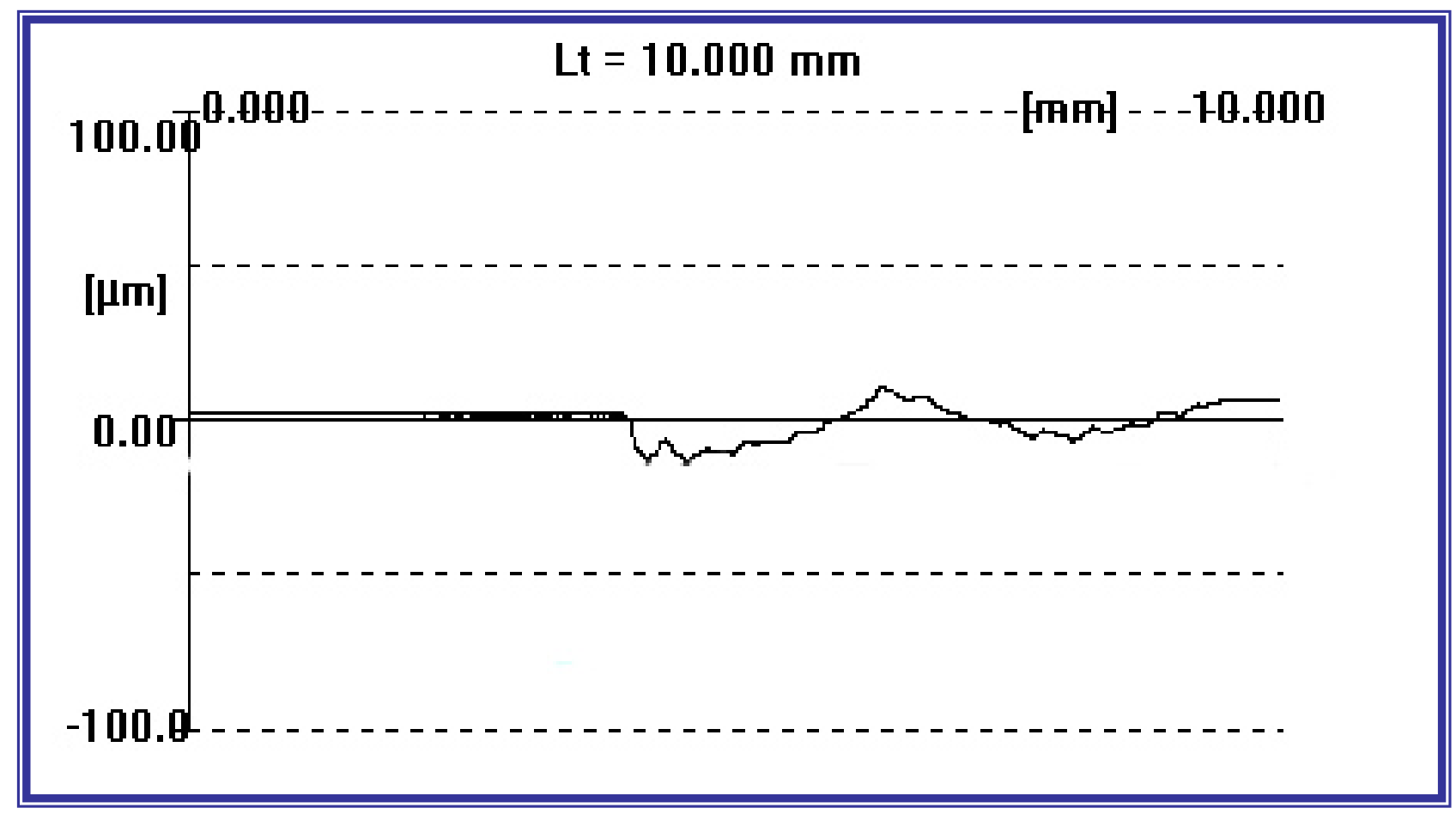

FIGURA 17 - Perfil real do G1 (VIP = $300 \mathrm{~mW} / \mathrm{cm}^{2} \times 20 \mathrm{~s}$ )

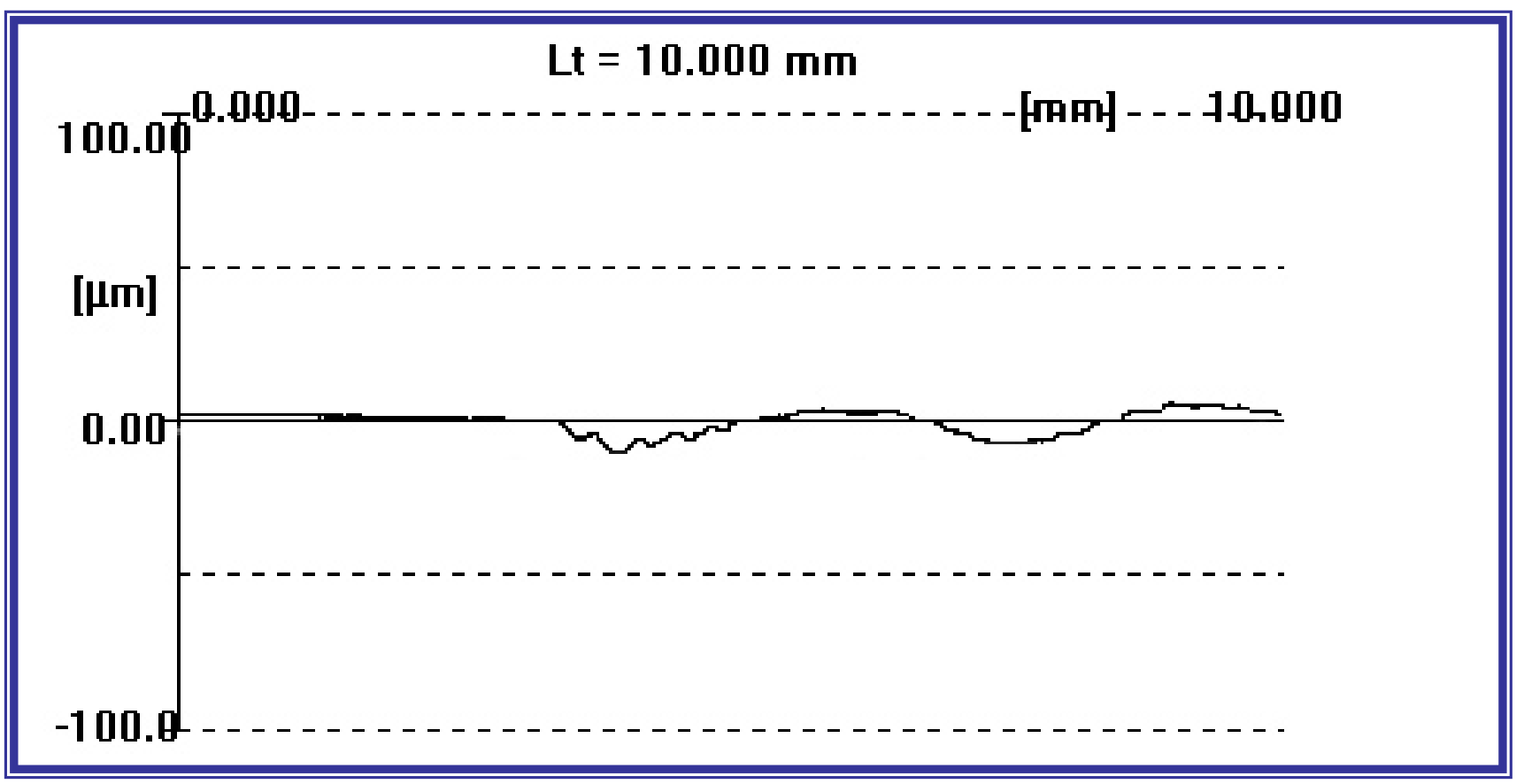

FIGURA 18 - Perfil real do G2 (VIP = $\left.600 \mathrm{~mW} / \mathrm{cm}^{2} \times 20 \mathrm{~s}\right)$ 


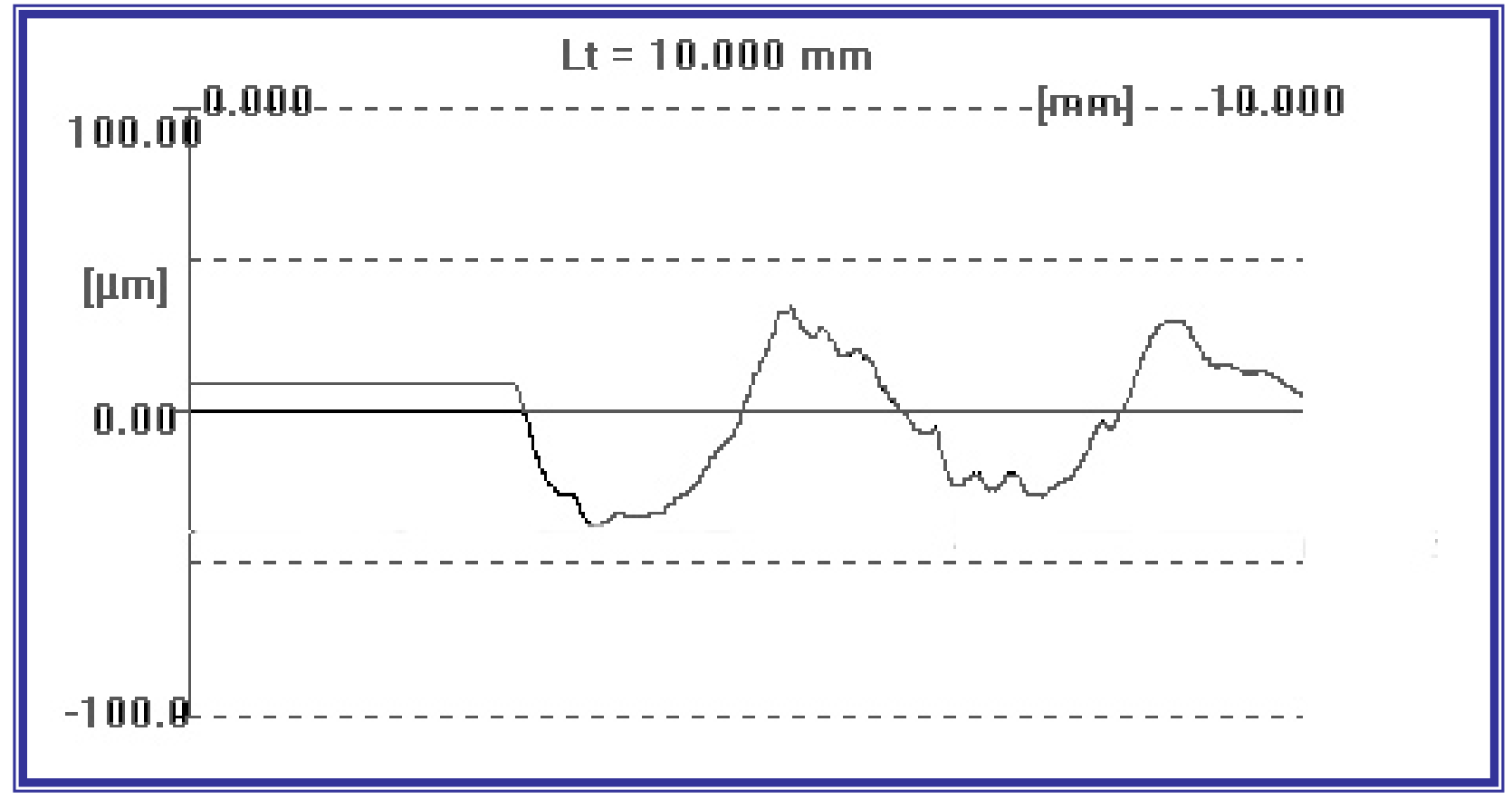

FIGURA 19 - Perfil real do G3 (LED = $\left.300 \mathrm{~mW} / \mathrm{cm}^{2} \times 20 \mathrm{~s}\right)$

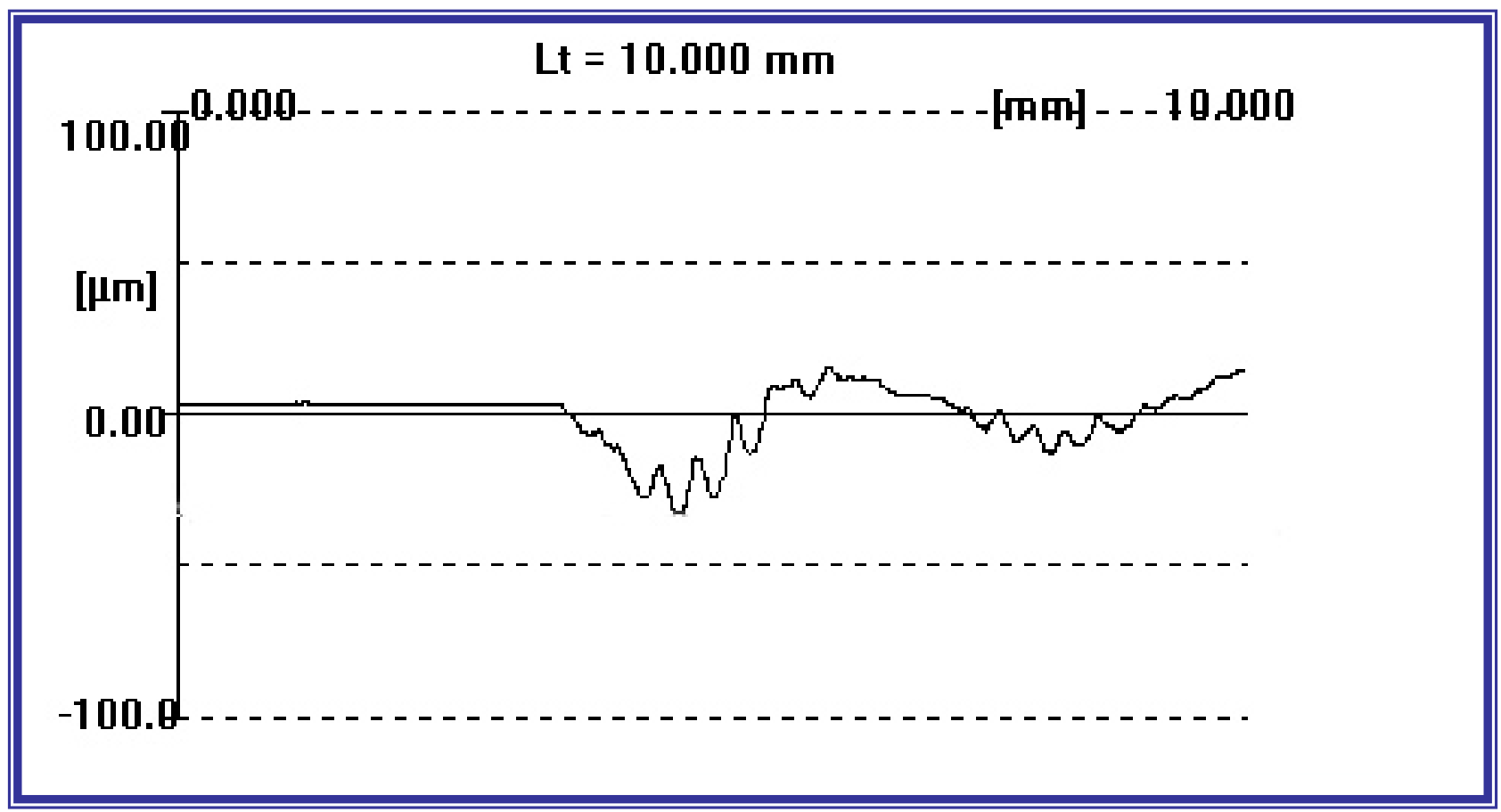

FIGURA 20 - Perfil real do G4 (LED = $600 \mathrm{~mW} / \mathrm{cm}^{2}$ x 20s) 
A análise de variância a dois critérios (tipo de aparelhos e diferentes densidade de potência) sobre a variação do desgaste mostrou haver diferença estatisticamente significante entre os grupos testados $(F=10.19 ; p<0,05)$. Na tabela 6 são apresentados os valores das médias de desgaste, desvio padrão e análise estatística após o teste de escovação simulada obtidos em cada condição experimental .

TABELA 6 - Média do desgaste $(\mu \mathrm{m})$, desvio padrão e análise estatística dos diferentes grupos estudados

Grupos Desgaste \pm DP $\quad$ Tukey*
G1 / HT
$13,96 \pm 0,756$
B

G2 I HS

$10,90 \pm 0,507$

A

G3 / LT

$34,63 \pm 1,931$

C

G4 / LS

$12,95 \pm 0,510$

B

* Letras iguais indicam não haver diferença estatisticamente significante

HT = Halógena trezentos $300 \mathrm{~mW} / \mathrm{cm}^{2}$

HS = Halógena seiscentos $600 \mathrm{~mW} / \mathrm{cm}^{2}$

$\mathbf{L T}=\mathrm{LED}$ trezentos $300 \mathrm{~mW} / \mathrm{cm}^{2}$

LS $=$ LED seiscentos $600 \mathrm{~mW} / \mathrm{cm}^{2}$

$p<0,05 ; n=10$ 
Dos quatro grupos avaliados, os espécimes fotoativados com lâmpada halógena demonstraram melhor comportamento mecânico (desgaste) diante do procedimento de abrasão (escovação simulada). É evidente observar como o $\mathrm{G} 2\left(\mathrm{VIP}=600 \mathrm{~mW} / \mathrm{cm}^{2} \times 20 \mathrm{~s}\right)$ foi o que apresentou menor desgaste $10,90 \mu \mathrm{m}$, seguido pelo G1 (VIP $\left.=300 \mathrm{~mW} / \mathrm{cm}^{2} \times 20 \mathrm{~s}\right)$, com desgaste de $13.96 \mu \mathrm{m}$ e do grupo G4 (LED = 600 $\left.\mathrm{mW} / \mathrm{cm}^{2} \times 20 \mathrm{~s}\right)$ com 12,95 $\mu \mathrm{m}$. O maior valor de desgaste, $(34,63 \mu \mathrm{m})$ foi apresentado pelo grupo G3 (LED $\left.=300 \mathrm{~mW} / \mathrm{cm}^{2} \times 20 \mathrm{~s}\right)$.

$\mathrm{Na}$ figura abaixo, encontra-se a representação ilustrativa dos valores médios do desgaste dos quatros grupos testados (Figura 21).

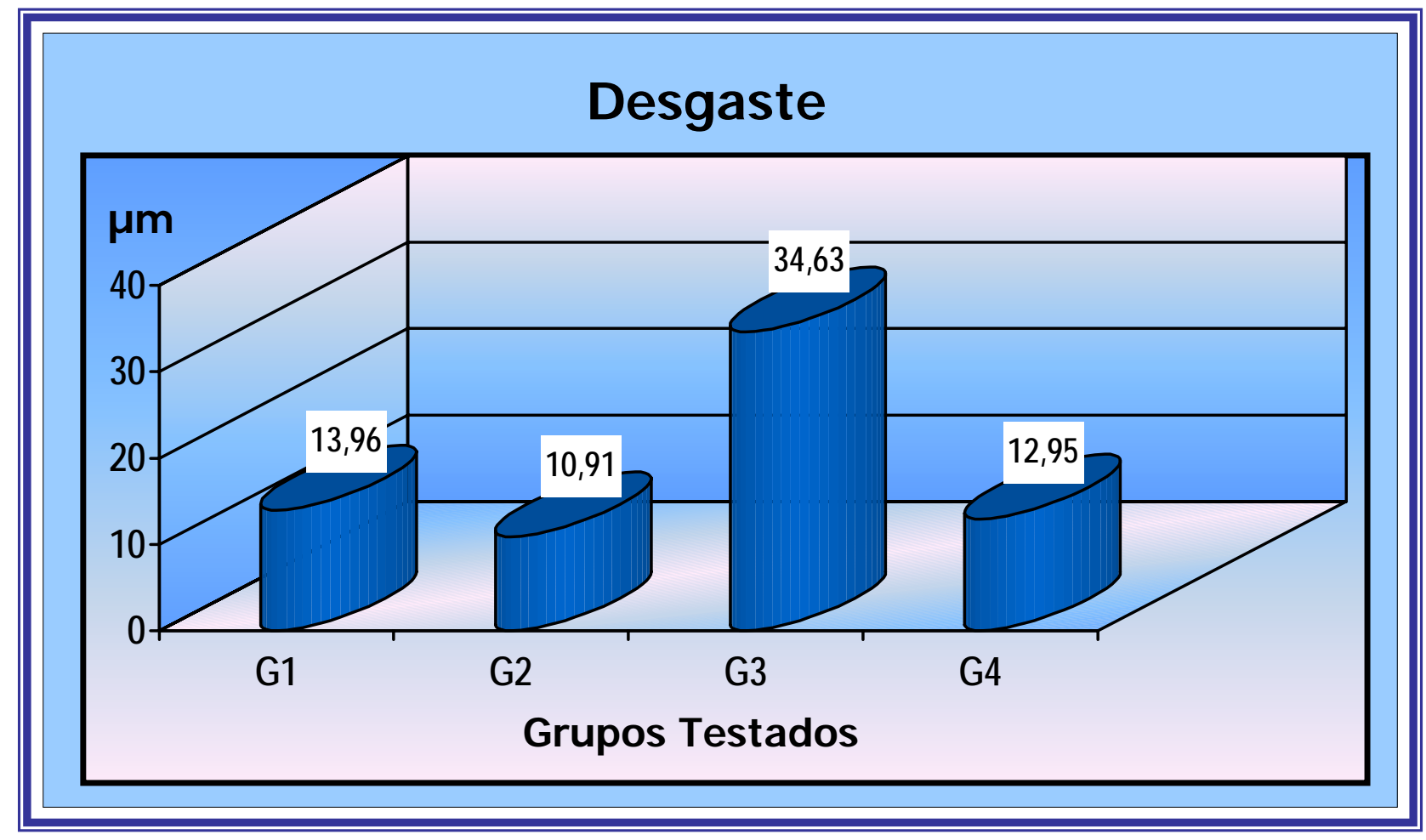

FIGURA 21 - Gráfico representativo dos valores médios de desgaste $(\mu \mathrm{m})$ dos diferentes grupos avaliados 


\subsection{Rugosidade superficial}

Para a determinação da rugosidade superficial dos espécimes o rugosímetro (Figura 9) foi ajustado com outros parâmetros. Para tal, a ponta apalpadora do aparelho foi programada para realizar um percurso de $5 \mathrm{~mm}$ (Lt $=$ limite de tracejamento), em escala de $20 \mu \mathrm{m}$. Empregou-se o parâmetro de filtragem ou minimização das ondas de superfícies (cut off - Lc $=0.25 \mathrm{~mm}$ ). As modificações desses parâmetros propiciaram nitidez às mudanças ocorridas nas superfícies mensuradas de cada corpo-de-prova, antes e após o procedimento de abrasão (Figura 22 e 23).

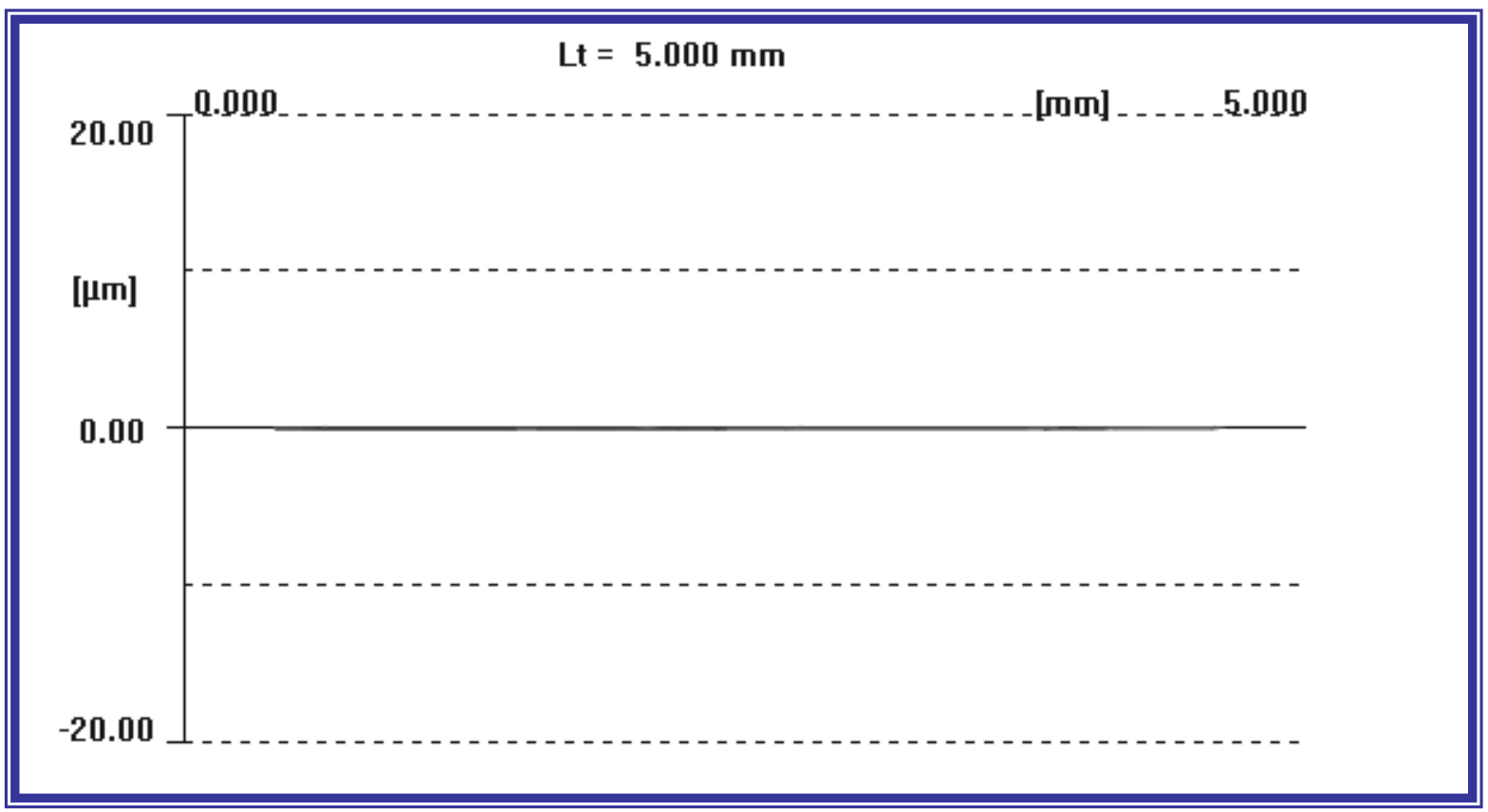

FIGURA 22 - Perfil de rugosidade superficial do corpo-de-prova em resina composta antes do procedimento de abrasão (lado controle) 


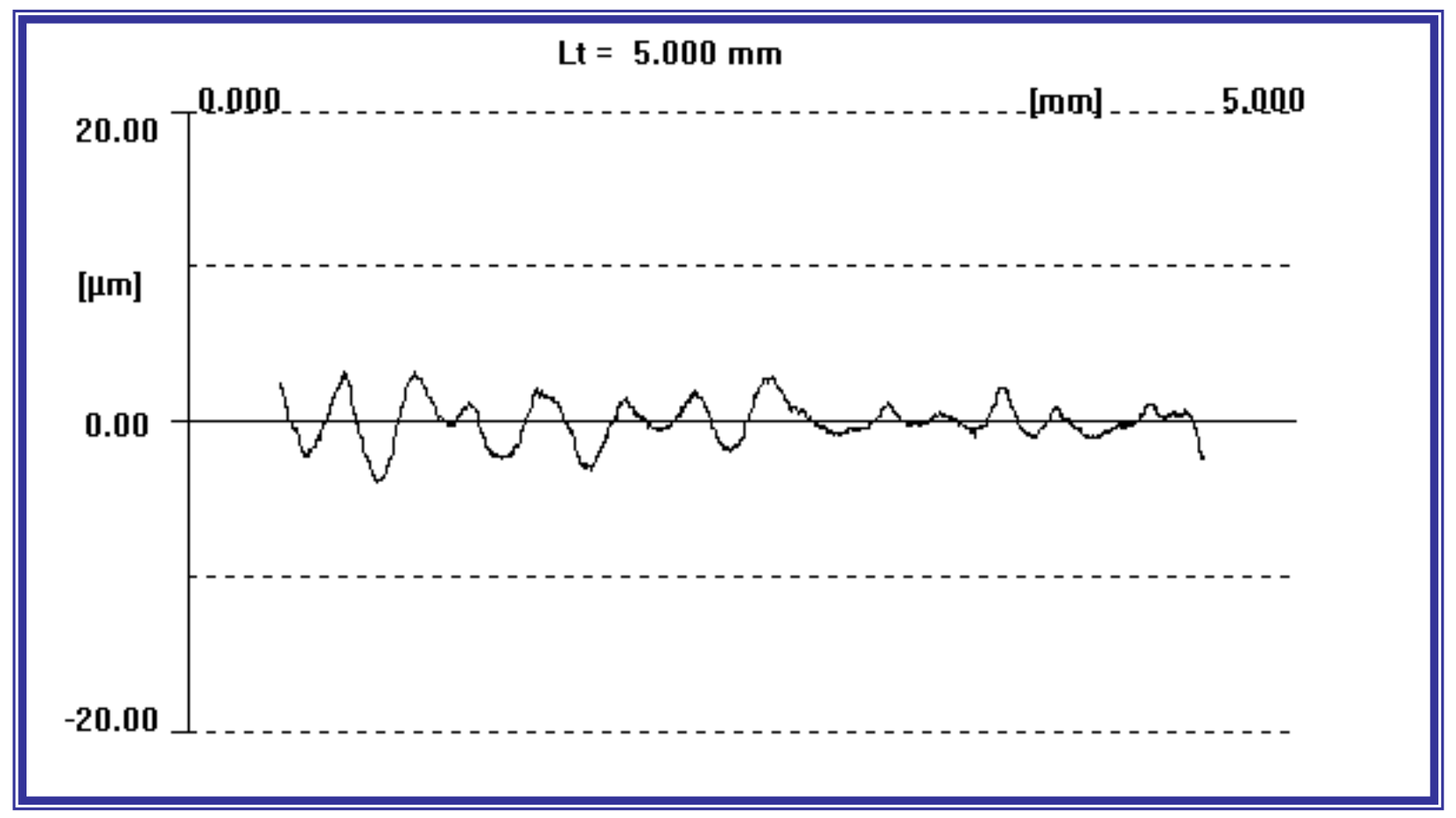

FIGURA 23 - Perfil de rugosidade superficial do corpo-de-prova em resina composta após o procedimento de abrasão (lado escovado)

A análise de variância a dois critérios (tipo de aparelhos e diferentes intensidades) sobre a alteração de rugosidade superficial não mostrou haver diferença estatisticamente significante antes $(\mathrm{RI})$ do procedimento de abrasão. Todavia, obedecendo aos mesmos critérios aplicados no procedimento anteriormente citado, verificou-se diferença estatisticamente significante após (RF) escovação simulada para os grupos avaliados, onde $F=67,6 ; p<0,05$. Portanto, tornou-se necessário à aplicação do teste de Tukey para comparações individuais entre os grupos. 
Segue-se os valores das médias das leituras registradas pelo rugosímetro Hommel Tester T1000 antes e após procedimento de abrasão (Tabela 7). Os valores expressos nesta tabela estão didaticamente ilustrados nos gráficos seqüenciais (Figuras 24 e 25).

TABELA 7 - Valores das médias de rugosidades $(\mu \mathrm{m})$ iniciais, finais, desvio padrão, diferenças e análise estatística dos grupos estudados

\begin{tabular}{c|cc|cc|cc}
\hline Grupos & RI \pm DP $($ Tukey*) & RF \pm DP & (Tukey*) & Diferença \pm DP (Tukey*) \\
\hline G1 / HT & $0,031 \pm 0,009$ & A a & $0,954 \pm 0,010$ & B b & $0,923 \pm 0,031 \quad$ B b \\
\hline G2 / HS & $0,032 \pm 0,010$ & A a & $0,923 \pm 0,044$ & A b & $0,891 \pm 0,036 \quad$ A b \\
\hline G3 / LT & $0,035 \pm 0,012$ & A a & $1,065 \pm 0,007$ & C c & $1,031 \pm 0,019$ & C c \\
\hline G4 / LS & $0,034 \pm 0,011$ & A a & $0,952 \pm 0,012$ & B b & $0,918 \pm 0,032$ & B b \\
\hline
\end{tabular}

* Letras iguais indicam não haver diferença estatisticamente significante

HT = Halógena trezentos $300 \mathrm{~mW} / \mathrm{cm}^{2}$

HS = Halógena seiscentos $600 \mathrm{~mW} / \mathrm{cm}^{2}$

$\mathbf{L T}=\mathrm{LED}$ trezentos $300 \mathrm{~mW} / \mathrm{cm}^{2}$

LS $=$ LED seiscentos $600 \mathrm{~mW} / \mathrm{cm}^{2}$

$p<0,05 ; n=10$ 


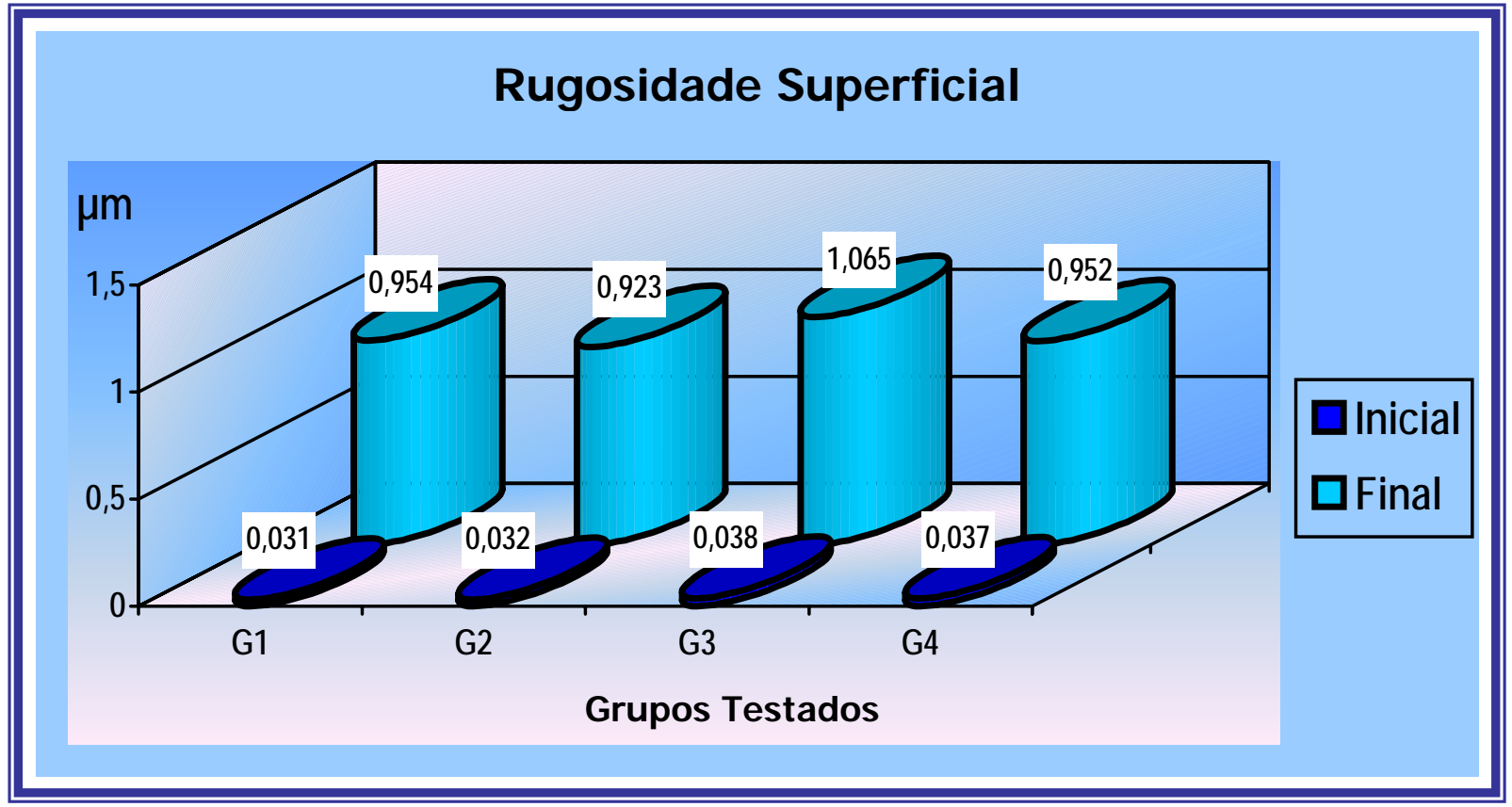

FIGURA 24 - Gráfico das diferenças entre os valores das rugosidades superficiais $(\mu \mathrm{m})$ antes e após o teste de escovação simulada

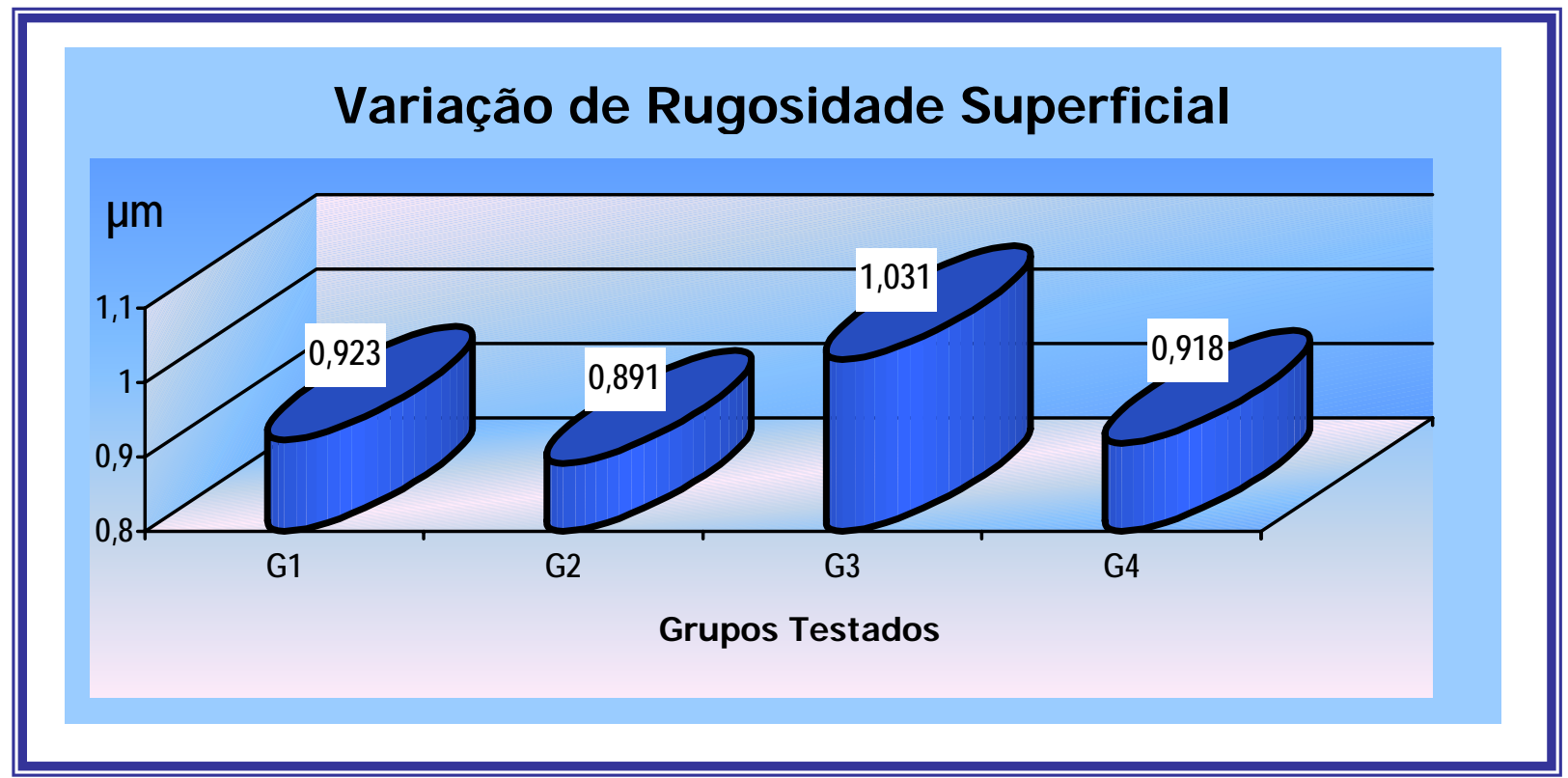

FIGURA 25 - Gráfico de variação da rugosidade superficial $(\mu \mathrm{m})$ dos grupos testados após a escovação 
A ordem crescente em termos de valores absolutos para alteração de rugosidade superficial foi o $\mathrm{G} 2\left(\mathrm{VIP}=600 \mathrm{~mW} / \mathrm{cm}^{2} \times 20 \mathrm{~s}\right)$ com $0,891 \mu \mathrm{m}$, o $\mathrm{G} 1$ $\left(\mathrm{VIP}=300 \mathrm{~mW} / \mathrm{cm}^{2} \times 20 \mathrm{~s}\right) \mathrm{com} 0,923 \mu \mathrm{m}$, o $\mathrm{G} 4\left(\mathrm{LED}=600 \mathrm{~mW} / \mathrm{cm}^{2} \times 20 \mathrm{~s}\right) \mathrm{com}$ $0,918 \mu \mathrm{m}$ e finalmente o $\mathrm{G} 3\left(\mathrm{LED}=300 \mathrm{~mW} / \mathrm{cm}^{2} \times 20 \mathrm{~s}\right)$ com $1,031 \mu \mathrm{m}$. Nota-se que os corpos-de-prova fotoativados com o LED $=300 \mathrm{~mW} / \mathrm{cm}^{2} \times 20 \mathrm{~s}$ (G3), apresentaram os maiores valores de alteração $(1,031 \mu \mathrm{m})$, propiciando assim, diferença estatisticamente significante em relação às demais condições experimentais.

Pelos valores constatados e após análise estatística, observa-se que o $\mathrm{G} 2\left(\mathrm{VIP}=600 \mathrm{~mW} / \mathrm{cm}^{2} \times 20 \mathrm{~s}\right)$ apresentou o melhor comportamento em termos de rugosidade superficial, obtendo o menor valor antes e após procedimento de abrasão. Os quatro grupos testados não demonstraram diferença estatisticamente significante antes (RI) da escovação simulada (Tabela 7). Entretanto, pode-se notar que o $G 3\left(\right.$ LED $\left.=300 \mathrm{~mW} / \mathrm{cm}^{2} \times 20 \mathrm{~s}\right)$ foi o que mostrou maior valor de rugosidade superficial e de desgaste após o teste de escovação simulada.

Quando todos os grupos foram submetidos ao teste de correlação de Pearson simultaneamente, não foi verificada a existência de correlação entre desgaste e rugosidade superficial $(p<0,05)$ onde $r=0,242 ; p=0,094$. 


\subsection{Ilustração qualitativa}

Um espécime de cada condição experimental foi selecionado para observar as modificações ocorridas na resina composta estudada, quando analisadas em microscópio eletrônico de varredura. Por meio da análise das figuras a seguir (Figuras 26 a 35), pode-se observar e comparar as alterações superficiais sofridas antes (lado controle) e após (lado escovado) a escovação simulada dos quatros grupos estudados.

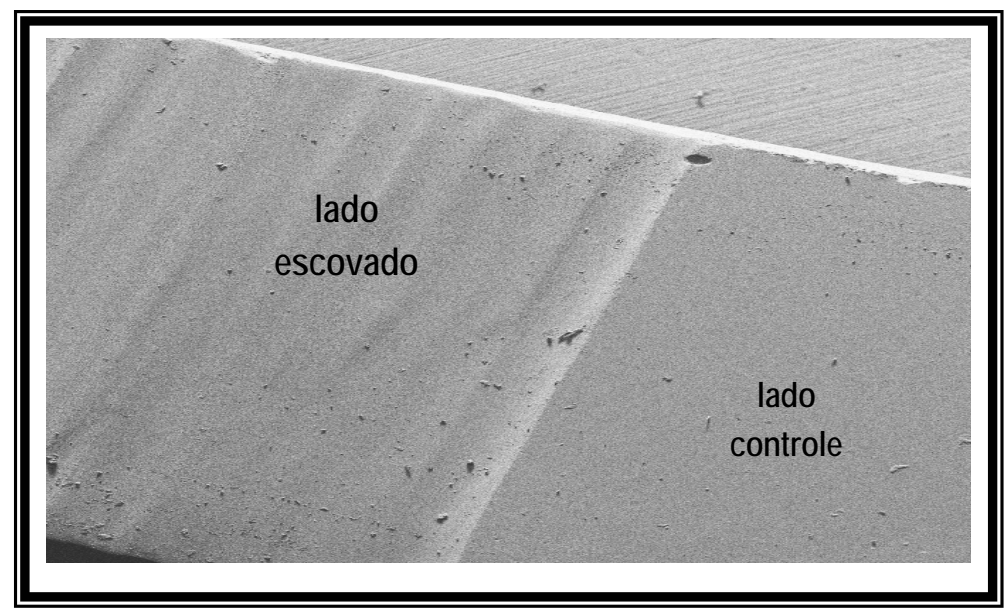

FIGURA 26 - Exemplo de uma fotomicrografia com 45x de aumento da resina composta testada antes (lado controle) e após (lado escovado) a escovação simulada

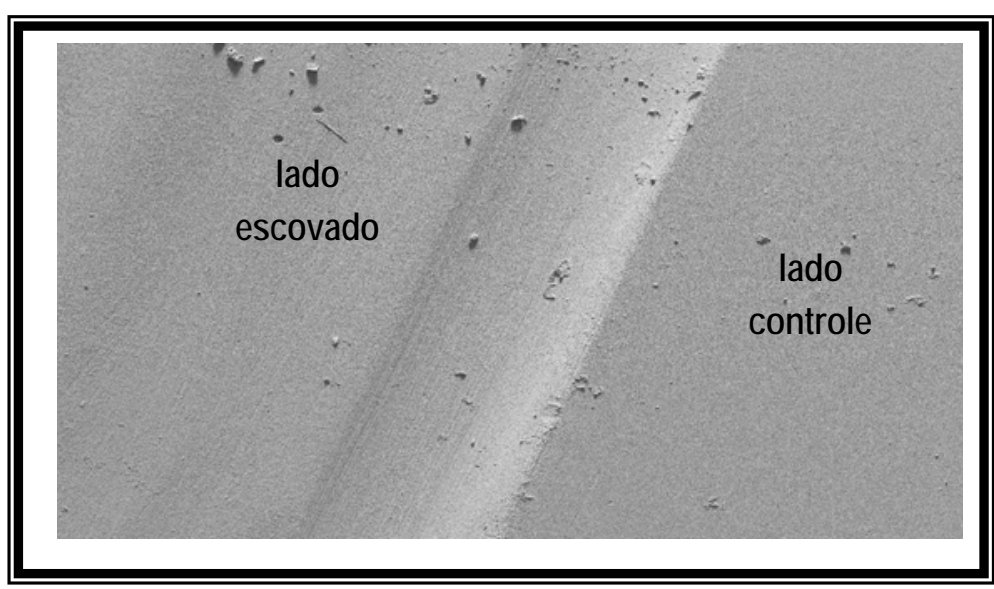

FIGURA 27 - Exemplo de uma fotomicrografia com 150x de aumento da resina composta testada antes (lado controle) e após (lado escovado) a escovação simulada 


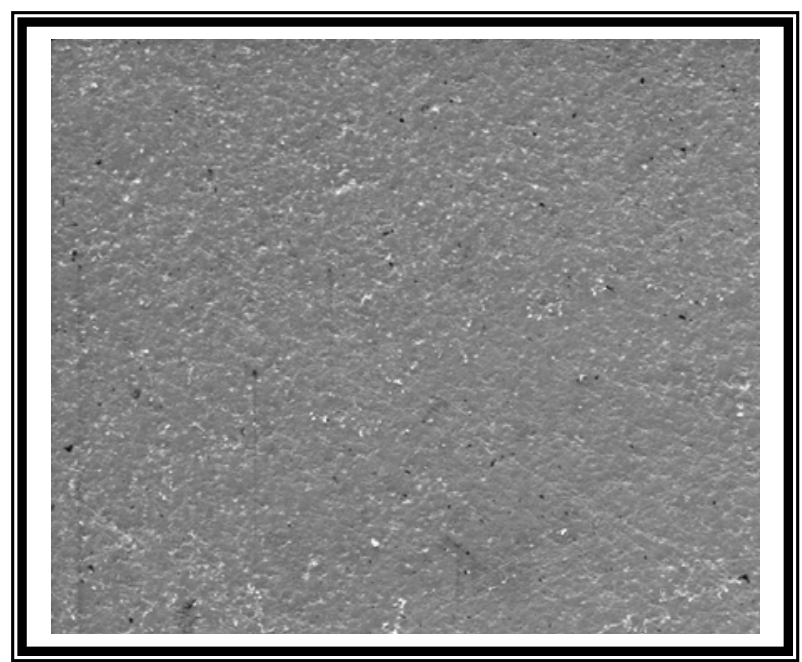

FIGURA 28 - Fotomicrografia com 1500x de aumento da superfície de resina composta do G1 (LH: $300 \mathrm{~mW} / \mathrm{cm}^{2} \times 20 \mathrm{~s}$ ) antes (lado controle) da escovação simulada

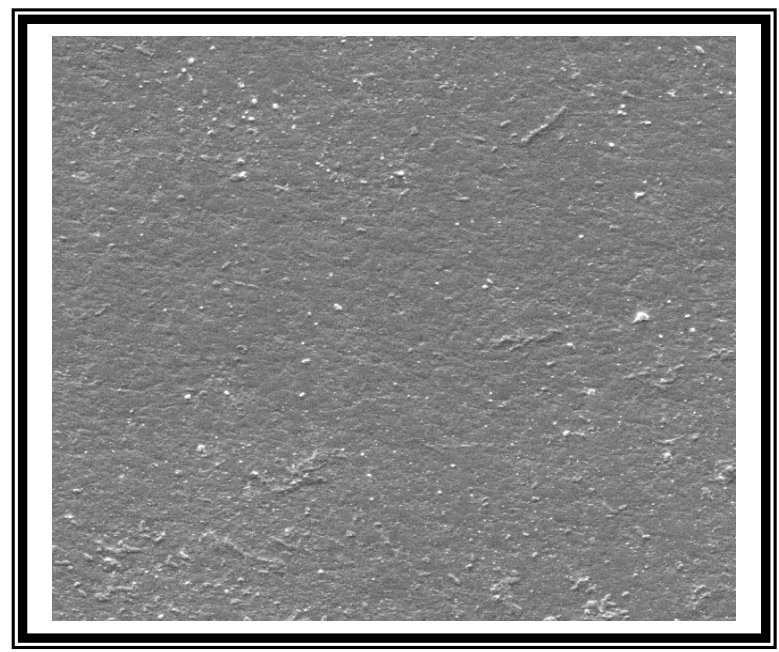

FIGURA 30 - Fotomicrografia com 1500x de aumento da superfície de resina composta do G2 (LH: $600 \mathrm{~mW} / \mathrm{cm}^{2} \times 20 \mathrm{~s}$ ) antes (lado controle) da escovação simulada

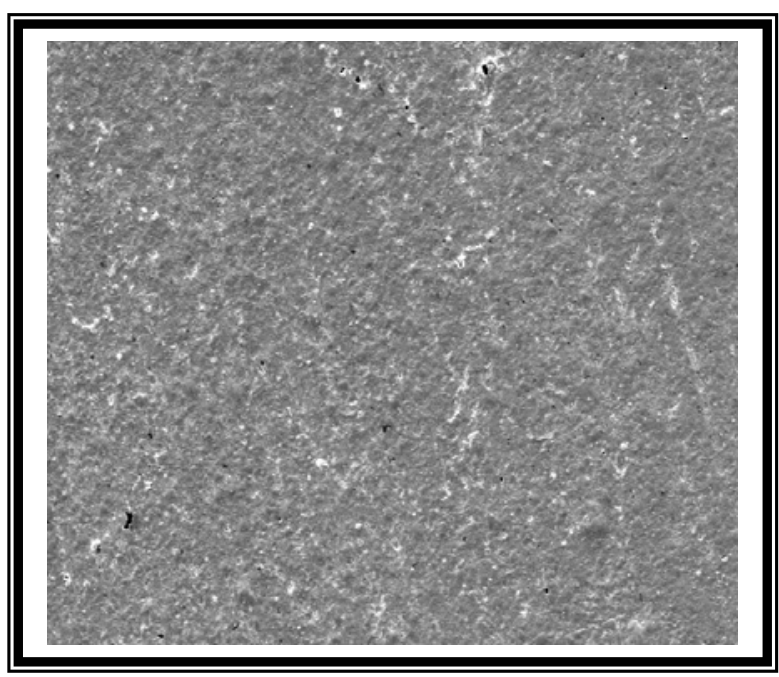

FIGURA 29 - Fotomicrografia com 1500x de aumento da superfície de resina composta do G1 (LH: $300 \mathrm{~mW} / \mathrm{cm}^{2} \times 20 \mathrm{~s}$ ) após a (lado escovado) escovação simulada

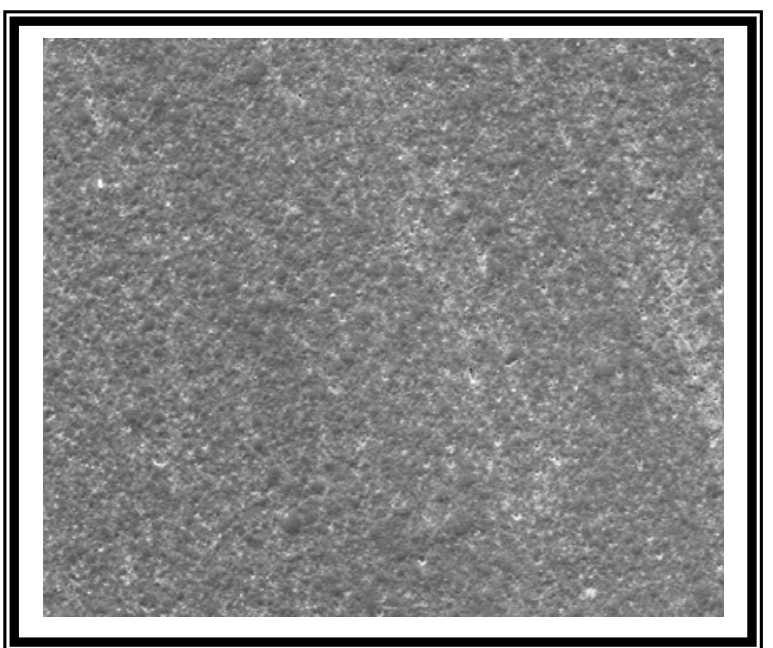

FIGURA 31 - Fotomicrografia com 1500x de aumento da superfície de resina composta do G2 (LH: $600 \mathrm{~mW} / \mathrm{cm}^{2} \times 20 \mathrm{~s}$ ) após (lado escovado) a escovação simulada 


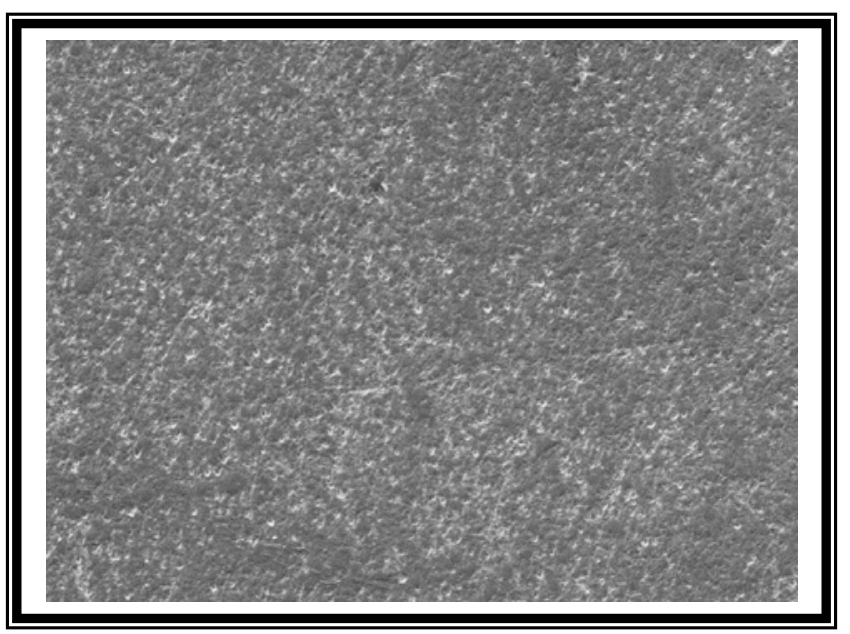

FIGURA 32 - Fotomicrografia com 1500x de aumento da superfície de resina composta do G3 (LED: $300 \mathrm{~mW} / \mathrm{cm}^{2} \times 20 \mathrm{~s}$ ) antes (lado controle) da escovação simulada

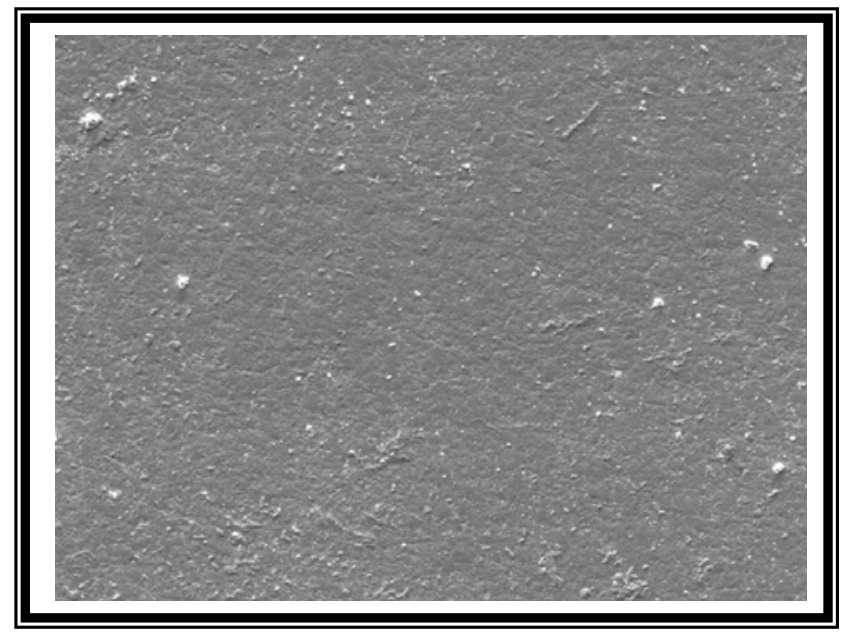

FIGURA 34 - Fotomicrografia com 1500x de aumento da superfície de resina composta do G4 (LED: $600 \mathrm{~mW} / \mathrm{cm}^{2} \times 20 \mathrm{~s}$ ) antes (lado controle) da escovação simulada

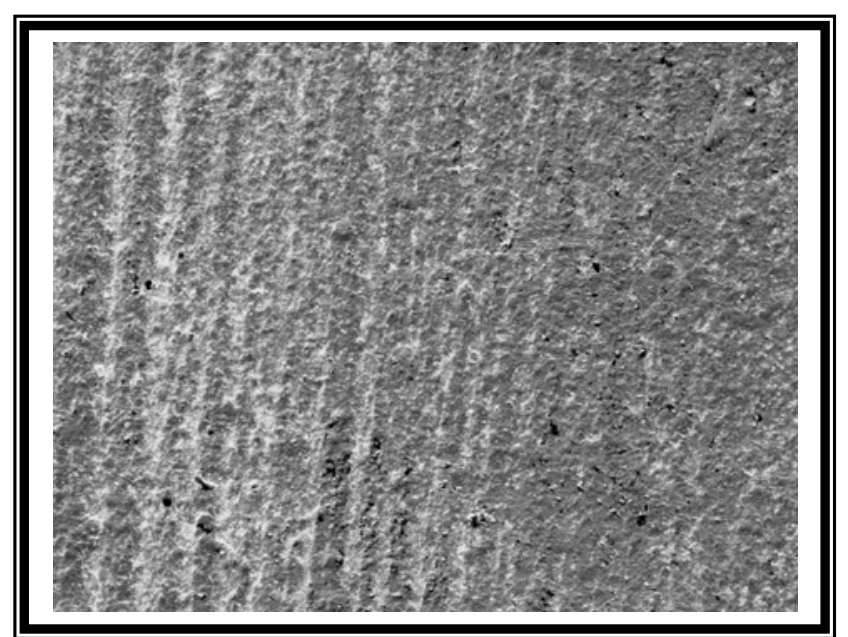

FIGURA 33 - Fotomicrografia com 1500x de aumento da superfície de resina composta do G3 (LED: $300 \mathrm{~mW} / \mathrm{cm}^{2} \times 20 \mathrm{~s}$ ) após (lado escovado) a escovação simulada

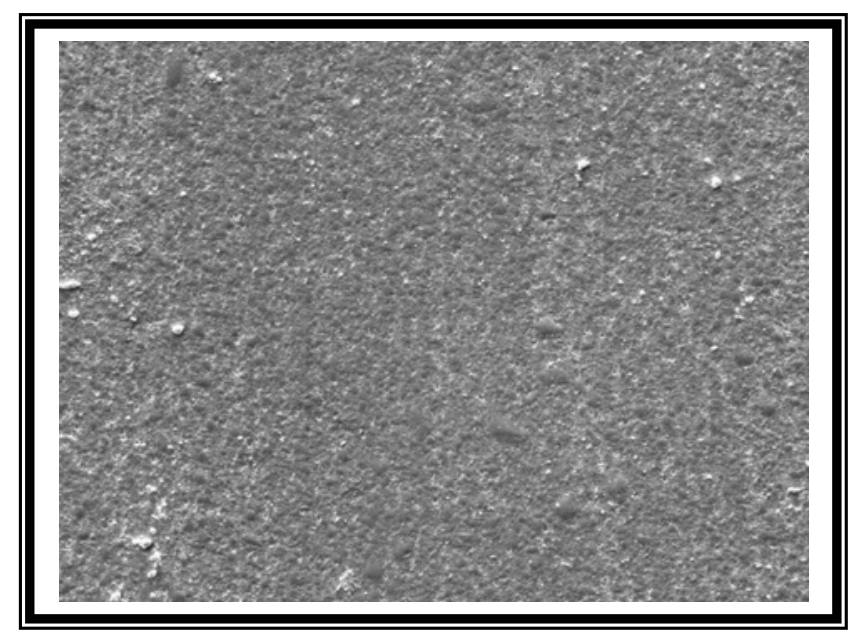

FIGURA 35 - Fotomicrografia com 1500x de aumento da superfície de resina composta do G4 (LED: $600 \mathrm{~mW} / \mathrm{cm}^{2} \times 20 \mathrm{~s}$ ) após a (lado escovado) a escovação simulada 
6 DISCUSSÃO 


\section{DISCUSSÃO}

\subsection{Metodologia empregada}

As resinas compostas, constituídas por substâncias poliméricas de composição orgânica e portanto, não metálicas, apresentam, por essa razão, limitações bastantes conhecidas como material restaurador odontológico, no que tange a sua resistência aos esforços mecânicos e toda gama de fatores adversos caracterizados pelo ambiente bucal.

Assim sendo, pode-se considerar que um dos maiores desafios encontrados na Odontologia diz respeito à resistência ao desgaste tanto dos substratos dentários, esmalte, por vezes dentina e cemento quando expostos, além dos materiais restauradores ${ }^{4,53,61,68}$. O aumento da expectativa de vida da população provocou mudanças no perfil dos pacientes, esperando-se maior longevidade dos elementos dentários e das restaurações presentes ${ }^{28,81,89,112}$. Desta forma, a tecnologia dos materiais odontológicos restauradores deve avançar no sentido de proporcionar melhor resistência e garantia de maior tempo de vida útil.

BISHOP et al. ${ }^{11}$ (1997) consideram o desgaste como um dos maiores desafios atuais, associando-o também ao estilo de vida e aspectos culturais que podem criar hábitos que levem à maior incidência. 
Para JONES; JONES; WILSON ${ }^{52}$ (1972), o desgaste, apesar de parecer familiar, é de difícil conceituação, estando associado à perda progressiva de substância da superfície de um corpo por ação mecânica.

Muitos são os tipos de desgaste que ocorrem na cavidade bucal: abrasão, atrição, erosão e abfração ${ }^{25,43,72,73,101}$. A maior dificuldade de se representar e avaliar tais comportamentos, mesmo in vitro, é o fato de que, para cada um destes processos, vários outros fatores associados estão envolvidos. Como tal, o desgaste é um processo complexo, dificultando um modelo laboratorial de investigação completo ${ }^{1,11}$. Deste modo, as investigações são normalmente realizadas de forma fragmentada, procurando-se criar condições mais próximas às encontradas clinicamente.

Particularmente, a abrasão ${ }^{52}$ é classificada como a remoção progressiva de material da superfície de um sólido por ação de corte de um material abrasivo. Este processo pode ser resultante de agentes etiológicos distintos, como esforço mastigatório ${ }^{43,60}$, movimentação do bolo alimentar durante mastigação ${ }^{29,116}$ e escovação dentária ${ }^{95,106,112}$.

É notável observar como vários autores ${ }^{42,48,, 86,87,90,96,97,112}$ investigaram metodologias capazes de retratar cada processo o mais realístico possível, fazendo comparações com avaliações clínicas. Estas são consideradas de grande relevância na investigação real das conseqüências do desgaste ${ }^{115}$. No entanto, trabalhos laboratoriais são de extrema importância por analisar cada fator isoladamente ${ }^{29}$. O trabalho clínico se depara com os fatores tempo e 
reprodutibilidade ${ }^{45,68}$. Para os dentes posteriores, o desgaste oclusal é de grande interesse, sendo a área mais exposta e sujeita à maior influencia destes fatores, como carga oclusal, abrasão pelo bolo alimentar e escovação dentária ${ }^{23,28}$.

Por tal motivo, as análises clínicas de mensurações quantitativa e qualitativa são muitas vezes efetuadas por métodos indiretos, por meio da duplicação de modelos ${ }^{25,61}$. No entanto, na avaliação in vitro, detalhes de desgaste são conseguidos com maior precocidade e capacidade de comparação em intervalos de tempo diferentes, acompanhando o fenômeno a longo prazo.

$\mathrm{Na}$ literatura são encontradas diversas formas para a avaliação de desgaste, tanto quantitativa como qualitativamente: microscopia eletrônica de varredura $^{1,29,44,45,97}$, perfilômetria ${ }^{43,46,57,63,66,68,72}$, perda de material (massa, volume, espessura $)^{68,87,102,112}$, perda de reflectância de luminosidade ${ }^{97}$ e uso de isótopos radioativos ${ }^{42}$. Sem dúvida, esta vasta quantidade de trabalhos demonstra a inquietação que existe no meio odontológico em relação à resistência ao desgaste de materiais restauradores de uso direto. Assim sendo, a metodologia empregada neste experimento, para determinar o desgaste quantitativo em micrometros, propicia o melhor entendimento do comportamento mecânico frente ao desgaste dos materiais avaliados em comparação aos métodos que utilizam à perda de massa ${ }^{87,112}$ como parâmetro, podendo ainda comparar estes resultados com os trabalhos clínicos avaliados. 
Além disso, deve-se ressaltar que esses materiais restauradores precisam, para otimizar e garantir suas propriedades mecânicas (desgaste e rugosidade superficial), de algumas condições básicas durante a fotoativação, tais como: energia suficiente (densidade de potência) do aparelho, correto comprimento de onda emitido e tempo de exposição adequado $^{13,17,18,36,91,94,96,114}$.

Com base nas considerações expostas acima, a metodologia eleita para o presente estudo constitui-se de um teste de escovação simulada, onde se avaliou o desgaste e rugosidade superficial de uma resina composta, em função de diferentes energias e fontes de luz (LH e LED).

Diante da necessidade de se padronizar todos os corpos-de-prova, foi confeccionada uma matriz $(15 \mathrm{~mm}$ de comprimento, $5 \mathrm{~mm}$ de largura e 4 espessura) para a realização deste estudo. Desta forma, estando a matriz com os braços fechados, foi acomodada à cavidade, com auxilio de uma espátula de inserção, uma primeira porção da resina composta com $2 \mathrm{~mm}$ espessura e $7,5 \mathrm{~mm}$ de comprimento. Esta primeira porção representa a metade do comprimento e a metade da altura da cavidade interna dos braços. Após fotoativação desta porção, procedeu-se as aplicações seqüenciais dos outros três incrementos de mesmas dimensões, até terminar a confecção do espécime. 
Previamente a fotoativação dos dois últimos incrementos uma tira de poliéster foi posicionada e sobre esta um dispositivo metálico de aço inoxidável, o qual, foi submetido a uma carga axial manual contínua por 30 segundos para causar extravasamento do excesso do material ${ }^{20}$.

$\mathrm{Na}$ confecção do corpo-de-prova foi escolhido este procedimento por favorecer uma sistemática aplicação da resina composta e satisfatória polimerização. Pois, os diâmetros das pontas dos dois aparelhos fotopolimerizadores testados (LH e LED) são de 8mm (Figura 7), condição favorável no momento da transmissão de luz e fotoativação da primeira porção e dos subseqüentes incrementos. Esta cobertura total do espécime é importante para promover polimerização uniforme em todo o seu diâmetro ${ }^{13,36}$.

Apesar de existir trabalhos de resistência ao desgaste, em que as amostras resinosas foram estocadas por 24 horas previamente aos ensaios $^{23,86}$, os estudos são praticamente unânimes em indicar estocagem de no mínimo 7 dias ${ }^{1,29,46,72,77,81,87,90,112}$. No presente estudo, os corpos-de-prova também foram armazenados em água deionizada por período de 7 dias. Tratase de um procedimento importante uma vez que trabalhos como HEATH; WILSON $^{45}$ (1976) e EHRNFORD et al. ${ }^{29}$ (1980) afirmam haver influência entre tempo de armazenagem em água e sorção de água pelos materiais resinosos. Os mesmos autores confirmam haver estabilidade da massa destes materiais resinosos em aproximadamente 5 dias de estocagem. Condição determinante na elaboração dos espécimes deste estudo. 
Obtidos os 40 corpos-de-prova e sabendo que o desgaste e irregularidades superficiais da resina composta a ser testada seriam microscópicos, a padronização de seu polimento permitiu a visualização exata da área desgastada, em função de dois fatores: a metodologia empregada para quantificação da perda do material (resina composta) e a forma como foi realizado o procedimento de escovação simulada, ou seja, na metade das superfícies polidas dos corpos-de-prova.

A escovação foi realizada por meio da ação mecânica da escova associada à ação do componente abrasivo do dentifrício selecionado, o carbonato de cálcio, sendo a escovação o principal fator de desgaste.

Para WANG ${ }^{112}$ (2001) a escovação é um método que utiliza três corpos, isto é, cerdas das escovas, pasta e superfície da resina composta. Este procedimento envolve qualquer área livre onde as cerdas das escovas possam atuar, atingindo áreas entre qualquer material restaurador dental, podendo-se ampliar às comparações com outros trabalhos em relação a diversos materiais.

O papel da escovação dentária é indiscutível, proporcionado inúmeros benefícios na higiene oral ${ }^{43,51,82}$, constituindo um dos principais responsáveis pelo declínio de cárie mundial, desde que seu uso foi associado aos dentifrícios fluoretados ${ }^{9}$. Além disso, auxilia na promoção de polimento e remoção de manchas $^{51}$. 
STOOKEY; MULHER ${ }^{101}$ (1968) demonstraram que a abrasividade está intimamente ligada à capacidade de remoção das manchas. Uma ação polidora existe, associada ao abrasivo, contribuindo para uma superfície lisa como demonstrado em estudo de SCHMIDLIN; SENER; LUTZ ${ }^{95}$. No entanto, esta ação benéfica é acompanhada por inconvenientes como o desgaste provocado no substrato escovado ${ }^{51,57,88}$, existindo a necessidade de se buscar um equilíbrio entre máxima limpeza e mínimo desgaste.

Dentro deste contexto, no presente estudo, as cabeças das escovas dentais Kolynos $(8 \mathrm{~mm})$ foram adaptadas e fixadas em dispositivos metálicos, paralelamente a metade do corpo-de-prova, área a qual seria submetida ao teste de escovação (lado escovado). Conforme o método proposto e planejado no estudo preliminar (piloto) desta pesquisa, a outra metade (lado controle) do mesmo corpo-de-prova foi protegida com uma fita isolante, permitindo uma clara identificação entre a área escovada e área controle, condição essencial para as mensurações do desgaste e alteração da rugosidade superficial (Figura 36).

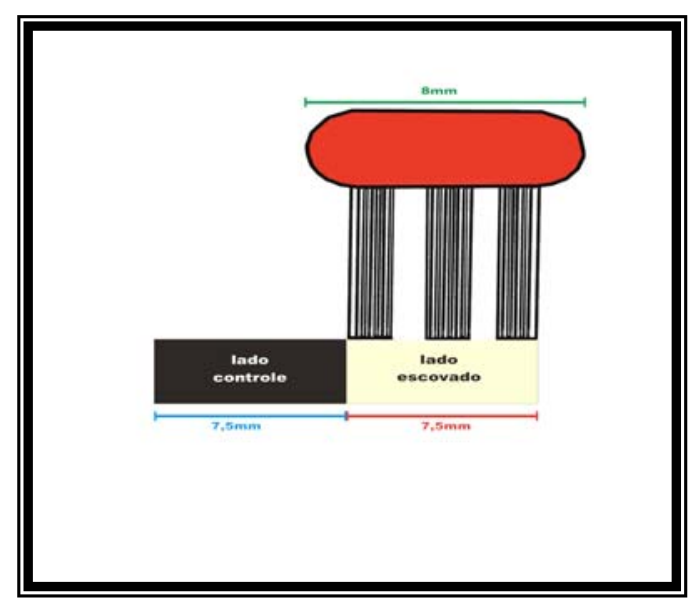

FIGURA 36 - Representação esquemática das dimensões exatas (em mm) da cabeça e posicionamento dos tufos da escova dental sobre o corpo-de-prova 
Vários outros recursos foram empregados com a finalidade de aproximar a condição experimental de escovação com a condição encontrada na cavidade oral. O equipamento simulador de escovação é dotado de um sensor de temperatura que viabiliza a escovação a temperatura de $37 \pm 2{ }^{\circ} \mathrm{C}$ por meio de monitoramento preciso e livre de interferências externas. A importância do monitoramento da temperatura é explicada por HEATH; WILSON ${ }^{45}$ (1976). Segundo esses autores, os diferentes materiais restauradores (amálgama, ouro e resinas químicas) apresentam comportamentos diferentes quando submetidos ao desgaste em temperatura ambiente ou a $37^{\circ} \mathrm{C}$, sugerindo que os testes sejam realizados a $37^{\circ} \mathrm{C}$ para que se aproximem da condição oral.

HARTE; MANLY ${ }^{44}$ (1976) também indicam a utilização da temperatura de $37^{\circ} \mathrm{C}$, segundo eles, a rigidez das cerdas das escovas dentais diminui em temperaturas mais elevadas quando em comparação à ambiente, por ação do calor, reduzindo em até $28 \%$ a sua capacidade abrasiva.

A amplitude da excursão dos movimentos de escovação varia na literatura de $15 \mathrm{~mm}^{9}$ a $85 \mathrm{~mm}^{51}$. A influência entre o comprimento do movimento da escova dental com o desgaste é explicada por HEATH; WILSON ${ }^{45}$ (1976). Em seu trabalho, quando utilizaram o comprimento de $45 \mathrm{~mm}$ associado a um dentifrício, o desgaste foi significantemente maior em relação ao comprimento de $15 \mathrm{~mm}$. Por outro lado, na ausência do dentifrício, o desgaste foi menor para o comprimento de $45 \mathrm{~mm}$ em relação ao de $15 \mathrm{~mm}$. Ainda, em percursos de $15 \mathrm{~mm}$, o desgaste foi igual quando o teste foi ou não associado ao dentifrício. 
Isto porque excursões maiores fazem diminuir o contato entre as cerdas e o espécime e, em excursões menores, desgastam os espécimes por ruptura de partículas.

Para o presente estudo, a excursão dos movimentos de escovação foi ajustado em $20 \mathrm{~mm}^{87}$, por se tratar de uma amplitude próxima da condição oral e também compatível com o tamanho do espécime (15mm $\times 5 \mathrm{~mm} \times 4 \mathrm{~mm})$.

A carga aplicada sobre os espécimes durante a escovação também exercer forte influência sobre o desgaste, esta correlação foi constatada no trabalho realizado por STOOKEY; MUHLER ${ }^{101}$ (1968). Os autores submeteram esmalte e dentina à teste de escovação simulada, com aumento progressivo da carga exercida pela escova, variando de 75 a 300g, e obtiveram aumento progressivo do desgaste para os dois substratos. Esses dados vêm de encontro aos obtidos por HEATH; WILSON ${ }^{45}$ (1976), onde sugerem que o aumento na carga de escovação leva a maior perda de material e que existe um limite de carga até o qual a escova irá exercer a sua função adequadamente, $7 \mathrm{~N}$. Acima deste valor ocorre um declive dos valores de desgaste, provavelmente devido ao "envergamento" das cerdas. O que se nota na literatura é uma margem grande dos valores de carga utilizados, variando de $75 \mathrm{~g}^{4}$ a $700 \mathrm{~g}^{45}$. Valores intermediários foram utilizados por uma série de outros pesquisadores, como DE GEE; TEM HARKEL-HAGENAAR; DAVIDSON ${ }^{25}$ (1985) que utilizaram 125g, WANG ${ }^{112}$ (2001) e $\operatorname{GARCIA}^{39}$ (2001) 200g, TURSSI $^{104}$ (2001), e PRAKKI ${ }^{87}$ (2003) utilizaram 300g, sendo este último valor o adotado para o presente estudo. 
Neste mesmo direcionamento, outra variável importante nos estudos de escovação é o tipo de diluente utilizado em associação ao dentifrício. Esta preocupação iniciou-se em 1972, por ASHMORE; VAN ABBE; WILSON ${ }^{4}$, onde os autores testaram a resistência ao desgaste de blocos de dentina ao dentifrício (a base de carbonato de cálcio) associado a dois diluentes, a água e o carboximetilcelulose. O resultado deste estudo demonstrou não haver diferença de desgaste quando da escolha destes dois diluentes. Em 1976, HARTE; MANLY ${ }^{44}$ também avaliaram o diluente utilizado em ensaios de escovação. Concluíram não haver diferença no desgaste entre o uso da saliva artificial e o carboximetilcelulose, entretanto, quando utilizaram a glicerina como diluente, notaram queda de $88 \%$ na capacidade de desgaste. Provavelmente, a sua viscosidade inibiu o potencial de abrasão do dentifrício. Quanto à concentração, notaram haver significante relação com a capacidade de desgaste, pois quando mais diluído o abrasivo, menor o desgaste.

Assim sendo, a suspensão utilizada para os testes deste trabalho consistiu de dentifrício dental (Colgate MFP), com abrasivo a base de carbonato de cálcio e água destilada deionizada ${ }^{104}$ na proporção de 1:2 em peso (ISO/TS 14569-1) ${ }^{47}$. Este dentifrício é considerado de média abrasividade ${ }^{9,83}$.

Um dos maiores desafios está na comparação dos resultados entre os trabalhos existentes na literatura pertinente. Mesmo quando a metodologia é bastante semelhante, são inevitáveis as diferenças nos detalhes. Neste sentido, uma das grandes arbitrariedades sobre os testes in vitro de resistência ao desgaste, utilizando ciclos de escovação simulada, refere-se à sua 
equivalência cronológica in vivo. $\mathrm{O}$ número de ciclos que simula 1 ano de escovação na cavidade oral varia de 4.320 a $16.000^{1}$ e de acordo com SEXSON; PHILLIPS ${ }^{97}$ (1951), a cada escovação o paciente costuma realizar 15 ciclos em uma determinada região. HEATH; WILSON ${ }^{45}$ (1976) testaram a resistência ao desgaste de uma série de materiais, entre eles, ouro, amálgama e resinas químicas. Quando os autores observaram o maior percentual de desgaste obtido pela resina sem carga Sevriton, calcularam que o esmalte na cavidade oral levaria cerca de 1750 anos para abrasão na ordem de $1 \mathrm{~mm}$, ignorando outras influências como a mastigação, hábitos e contatos oclusais. Assim, concluem afirmando que 20.000 ciclos de escovação simulada equivaleriam a aproximadamente 10 meses in vivo. Esta mesma correlação foi aplicada por DE GEE; TEM HARKEL-HAGENAAR; DAVIDSON ${ }^{25}$ (1985), onde submeteram resinas autopolimerizáveis a 2.600 ciclos por hora e relacionaram este número a aproximadamente 1 mês de escovação na boca. Já JONES; FISHER; WILSON ${ }^{51}$ (1985) relacionam o número de ciclos utilizados em seus estudos, 60.000 no total, a 18 meses de escovação in vivo. Para HARRINGTON et al. ${ }^{43}$ (1982) 240.000 ciclos equivalem a 4 anos de escovação intra-oral. A correlação mais crível parece ser a estabelecida por BUCHALLA; ATTIN; HELLWIG ${ }^{16}$ (2000). Segundo este trabalho, um paciente costuma realizar em média 4,5 ciclos de escovação por segundo, supondo que cada sextante é escovado por cerca de 20 segundos, 90 ciclos serão realizados até o término do procedimento, de forma que 6.000 ciclos de simulação equivaleriam a aproximadamente 1 a 2 meses na cavidade oral. No trabalho de dissertação de PRAKKI ${ }^{87}$ (2003), os corpos-de-prova dos matériais resinosos 
avaliados foram submetidos a 100.000 ciclos de escovação simulada, equivalendo em média a 2 anos de escovação in vivo. Com base nesta experiência, no presente estudo a metade (lado escovado) dos quarenta corpos-de-prova confeccionados em resina composta foram submetidos a 200.000 ciclos de escovação simulada, equivalendo em média a 4 anos de escovação na cavidade oral.

A metodologia aplicada procurou seguir os padrões utilizados rotineiramente na realização de um procedimento restaurador com resina composta. Assim, uma das principais preocupações concentrou-se na fase de polimerização, pois uma polimerização insuficiente da resina composta está entre as principais causas de fracasso clínico $5,7,13,18,20,22,38,49,91,94,105$. Segundo FRANCO; LOPES $^{36}$ (2003), uma polimerização deficiente está associada à redução das propriedades químico-mecânicas das resinas compostas, podendo resultar em menor dureza superficial, diminuição da resistência à compressão e aumento da possibilidade de deslocamento da restauração devido à menor retenção. Portanto, o sucesso clínico de uma restauração está diretamente relacionado à quantidade dos polímeros formados pelo processo de polimerização.

Além destes aspectos, as características específicas da categoria de materiais restauradores devem ser consideradas ${ }^{36,78}$. EHRNFORD et al. ${ }^{28}$ (1980) apontam os fatores inerentes à resina composta que influenciam no seu comportamento: composição da matriz orgânica; composição das partículas efetividade do agente silano; tamanho, distribuição, forma e volume das 
partículas, tamanho e localização da cavidade; magnitude, localização e direção das forças oclusais, grau de polimerização e técnica restauradora aplicada. No presente trabalho, foi selecionada uma resina composta fotopolimerizável de alta densidade com partículas micro-híbridas, a Filtek ${ }^{T M}$ Z250, (3M/ESPE, USA). Esta resina tem como matriz orgânica o componente Bis-GMA e como diluente principal o trietileno-glicol-dimetacrilato (TEGDMA). A carga inorgânica é constituída por zircônia e por sílica, totalizando $78 \%$ (em peso) do material ${ }^{99}$.

Uma lisura máxima é desejada, evitando o acúmulo de placa e suas conseqüências, como demonstrado por LINDQUIST; EMILSON ${ }^{67}$ (1990), principalmente quando são realizadas restaurações em resinas compostas na região posterior. Portanto, previamente à indicação de um material restaurador, suas propriedades frente ao desgaste e alteração da rugosidade superficial devem ser analisadas simultaneamente.

Dentro deste contexto, as medições da rugosidade superficial deste estudo foram realizadas por meio do Rugosímetro Hommel Tester T100 Hommelwerke $\mathrm{GmbH}$. De maneira similar a outros estudos ${ }^{46,57,66,72,87,90,112}$ para mensurar a rugosidade superficial, o padrão de leitura utilizado foi a rugosidade aritmética ( $\mathrm{Ra}$ ) ou roughness average, ou seja, a média aritmética entre os picos e vales percorridos pela ponta apalpadora do aparelho. O valor do cut-off utilizado foi de $0,25 \mathrm{~mm}$; este parâmetro determina o filtro utilizado durante a medição, ou seja, em áreas rugosas com comprimentos de onda menores o 
valor de $0,25 \mathrm{~mm}$ é utilizado para determinar o perfil de rugosidade, enquanto em superfícies onduladas com comprimentos de onda maiores são utilizados valores de cut-off maiores ${ }^{10}$. O limite de tracejamento, que é a extensão real percorrida pela ponta ativa do aparelho, foi programada para $5 \mathrm{~mm}$.

Para cada superfície do corpo-de-prova foram realizadas cinco leituras aleatórias, passando sempre pelo seu centro, o valor de rugosidade superficial foi obtido através da sua média aritmética. SUZUKI; LEINFELDER; SHINKAI ${ }^{102}$ (1995) adotaram a realização de 8 leituras de rugosidade por corpo de prova, outros como CORRER SOBRINHO et al. ${ }^{23}$ (2001) e TURSSI ${ }^{104}$ (2001) adotam a realização de três leituras. No presente trabalho, por ser tratar de um número estatisticamente suficiente, adotou-se realizar 5 leituras.

Baseados em alguns trabalhos ${ }^{10,34,72,87,90,112}$ e recentemente demonstrado no artigo de RICHMOND; MACFARLANE; McCORD ${ }^{89}$ (2004), os quais salientaram que a determinação da $\mathrm{Ra}$ empregando o rugosímetro para detectar alteração de superfície é, graças a sua alta resolução, o sistema de maior fidelidade. A forma geométrica da sua ponta ativa, cuja extremidade é de diamante, apresenta-se em formato de triângulo eqüilátero com $5 \mu \mathrm{m}$ de lado.

Por esta razão, HONÓRIO ${ }^{46}$ (2003) e outros autores ${ }^{57,87,90,112}$, quantificaram o desgaste resultante de procedimentos profiláticos e abrasivos por meio de perfilômetria, por considerarem este um método mais simples e direto para este tipo de mensuração. Neste trabalho, apoiado nas vantagens que oferece este método, foi utilizado para a mensuração do desgaste dos corpos-de-prova de resina a perfilômetria por meio do mesmo Rugosímetro Hommel Tester T100 - Hommelwerke GmbH. Porém, para a mensuração dos 
valores de desgaste, foram utilizados outros parâmetros na programação do aparelho. Nesta oportunidade, o valor do cut off foi $0.00 \mathrm{~mm}$ e o limite de tracejamento de $10 \mathrm{~mm}$.

Desta maneira, o perfil traçado unidirecionalmente pelo rugosímetro percorreu a superfície dos corpos-de-prova passando pela metade protegida (lado controle) e pela metade não protegida (lado escovado). Como o lado controle não foi escovado e se assemelhava a uma linha reta, tornou-se fácil à identificação da região submetida à escovação (lado escovado). Aspecto que pode ser facilmente avaliado na figura 37.

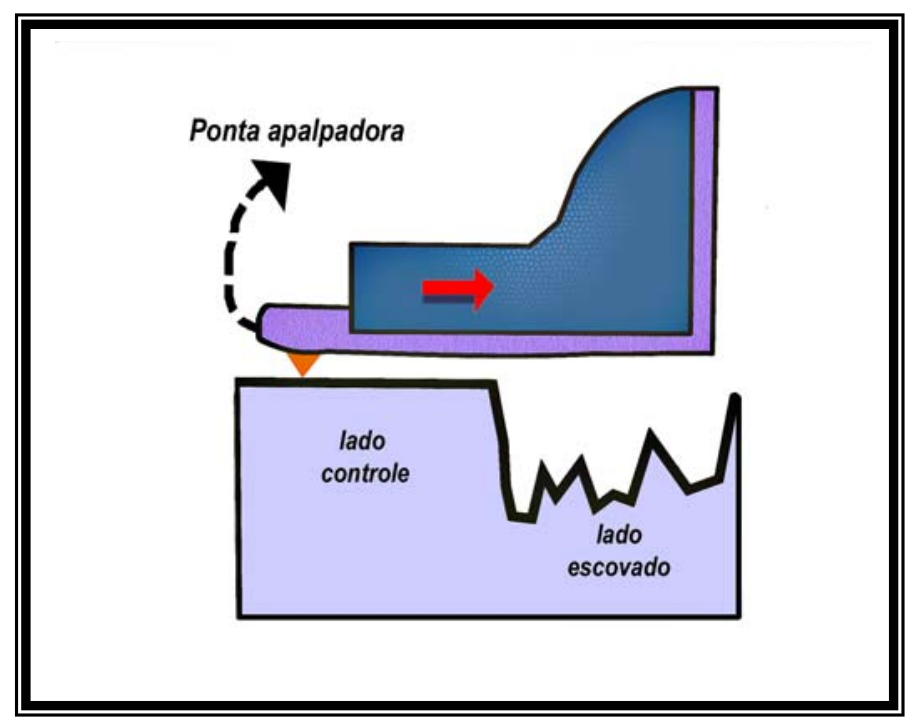

FIGURA 37 - Ilustração esquemática mostrando a direção de leitura feita pela ponta apalpadora do Rugosímetro para a quantificação do desgaste

O desgaste da resina composta foi quantificada pelo perfil real medindose à distância em micrometros $(\mu \mathrm{m})$ da linha média do gráfico, correspondente à linha do plano da área protegida (lado controle) do espécime, até o maior vale correspondente à área escovada (Figura 16). 
Certamente, frente ao envolvimento e interação das diferentes variáveis apontadas na descrição desta metodologia, considera-se oportuno salientar que durante o levantamento bibliográfico desta pesquisa não foi encontrado na literatura um artigo que avaliasse, após escovação simulada, em um mesmo espécime, o comportamento mecânico, em termos de desgaste e rugosidade superficial de resinas compostas, em função de diferentes energias e fontes de luz (LH e LED) usadas na polimerização. Como tal, a comparação dos resultados obtidos através dos inúmeros trabalhos que utilizam aparelhos de fotoativação para a polimerização de materiais resinosos se torna difícil em decorrência das variações existentes em cada metodologia, uma vez que não existe uma completa padronização destes ensaios.

No entanto, com a metodologia aplicada neste estudo foi possível avaliar o desgaste e a rugosidade superficial, após escovação simulada, de uma resina composta, em função de diferentes energias e fontes de luz, permitindo, assim, a discussão dos resultados no seguinte item.

\subsection{Resultados obtidos}

Neste estudo, foi avaliado o desgaste e a rugosidade superficial de uma resina composta, em função de diferentes energias e fontes de luz usadas na polimerização. Para iniciar a fotoativação de uma resina composta, é necessário que haja uma fonte de luz capaz de excitar o iniciador fotossensível, que normalmente é a canforoquinona $(C Q)^{5,13,18,20,22,27,38,50,65}$. A possibilidade da luz, por meio de suas unidades de energia (fótons), em ativar este iniciador 
fotossensível é ditada pela sua energia individual, a qual é determinada pelo comprimento de onda emitido pela luz ${ }^{36,50,59,103}$. Com base nesta afirmativa, PEUTZFELDT $^{84}$ (1994) salienta que um dos principais elementos que influencia o comportamento mecânico e, conseqüentemente, o desempenho clínico das restaurações em resina composta, em função do desgaste e da alteração da rugosidade superficial, é a qualidade da luz ativadora.

Durante a polimerização da resina composta parte da luz que penetra no material sofre dispersão na interface matriz/partícula, além de ser absorvida por estes dois componentes. A luz penetra na superfície da restauração, mas sua absorção impede que adentre nas porções mais profundas. Deste modo, o grau de polimerização da resina composta depende de sua composição e da interação entre os fatores que dificultam ou facilitam a transmissão da luz, tais como: propriedades ópticas da mistura resina/partícula, tamanho e quantidade de partículas ${ }^{36,37,38,114}$, concentração do fotoiniciador e espessura de material. No entanto, para qualquer formulação de material, as características de cura são governadas principalmente pela efetividade da fonte de irradiação, considerando a densidade de potência emitida, a distribuição da mesma no espectro de luz visível, o alinhamento da fonte ativadora e tempo de ativação $^{65,84}$.

Tal como destacam FRANCO; LOPES $^{36}$ (2003) e BOSQUIROLI ${ }^{13}$ (2003), desde o final da década de 70 o aparelho de luz hológena (LH) é o mais usado na polimerização de materiais fotossensíveis por profissionais da 
área odontológica, sendo denominado como o aparelho convencional. Este aparelho emite luz incandescente e, basicamente, compõe-se de uma lâmpada de filamento de tungstênio (bulbo e refletor), filtro, sistema de refrigeração (ventilação) e fibras ópticas para condução de luz. O filamento de tungstênio se encontra protegido em uma cápsula de quartzo com gases inertes, sendo conectado a um eletrodo para passagem da corrente elétrica. Como este filamento é submetido à altas temperaturas e produz luz dentro de uma larga faixa de comprimento de onda, incluindo a radiação na região do infravermelho, o mesmo é responsável pela emissão de calor.

A energia luminosa emitida por esta luz é tão vasta quanto a luz branca, ou seja, nem toda luz gerada em determinado comprimento de onda é necessária para 0 processo de fotopolimerização ${ }^{74}$. Por esta razão os fabricantes utilizam um filtro entre a lâmpada e o guia de luz, para limitar a energia radiante emitida na extensão necessária à polimerização, ou seja, dentro da banda de absorção da canforoquinona $(C Q)^{79}$. O filtro também possui a finalidade de eliminar calor desnecessário e incandescência da energia em excesso, não utilizada na fotopolimerização. Mesmo apresentando um sistema de resfriamento, a produção de altas temperaturas leva à degradação do bulbo, refletor e filtro, reduzindo gradativamente a densidade de potência do aparelho, podendo comprometer a efetividade de polimerização das restaurações de resina composta. Com a colocação do filtro, $10 \%$ da intensidade de luz gerada diminui $^{22,36,100}$. 
Estes aparelhos com lâmpadas halógenas geralmente operam na faixa de comprimento de onda entre $400-500 \mathrm{~nm}$, referente ao espectro de luz emitida, porém com valores de densidade de potência variando entre 300 $\mathrm{mW} / \mathrm{cm}^{2}$ a $1000 \mathrm{~mW} / \mathrm{cm}^{2} 4,13,36,37,59,65,79,91,94$. O aparelho de luz halógena (VIP Bisco) utilizado neste estudo apresenta a possibilidade da programação de sua densidade de potência variando entre $100 \mathrm{~mW} / \mathrm{cm}^{2}$ a $600 \mathrm{~mW} / \mathrm{cm}^{2}$. Para sua padronização da mesma energia utilizada para obtenção dos grupos experimentais, o aparelho foi programado em $300 \mathrm{~mW} / \mathrm{cm}^{2}$ e $600 \mathrm{~mW} / \mathrm{cm}^{2}$, em semelhança ao aparelho de luz LED empregado.

Como já relatados, todos estes aparelhos apresentam o mesmo mecanismo de obtenção da luz, portanto, a diferença para FRANCO; LOPES ${ }^{36}$

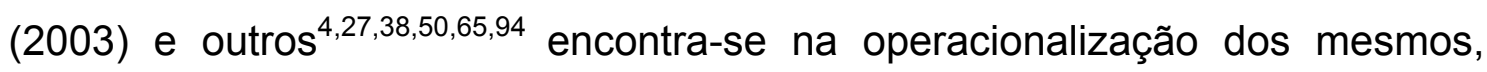
como por exemplo: ser digital, ter acoplado um mensurador da densidade de potência do aparelho (radiômetro), opções para modulação da fotoativação (polimerização gradual, pulso interrompido etc.).

Fica claro, que para aparelhos de LH a qualidade de luz emitida é determinada pela idade do bulbo, onde a integridade do refletor de luz deverá estar livre de manchamentos e opacidade, para adequada filtração da luz ${ }^{91}$. Como tal, é evidente pelas considerações acima apontadas que o tempo de vida útil de uma LH é relativamente curto, estima-se cerca de 50 - 100 horas clínicas. Ainda, se a lâmpada é freqüentemente ligada e desligada, o tempo de 
vida do bulbo se encurta ${ }^{13,36}$. Deste modo, para os aparelhos de luz halógena, a intensidade de luz é inversamente proporcional à idade da unidade ${ }^{38,50}$.

Ao contrário dos aparelhos de LH, o mecanismo pelo qual a luz é gerada nos aparelhos LED é mais simples. O LED (diodo emissor de luz) é uma combinação de semicondutores (Índio-Gálio-Nitrogênio), que emitem luz azul por mecanismo de eletroluminescência. Um semicondutor para produzir luz necessita da aplicação de uma tensão para vencer a barreira de energia interna. Constitui-se na combinação de dois semicondutores, um tipo n, que tem excesso de elétrons e o outro tipo $p$, que tem falta de elétrons, mais rico em lacunas ou buracos receptores de elétrons ${ }^{36}$. Deste modo, quando uma tensão é aplicada entre estes dois semicondutores, haverá a passagem de elétrons da camada $\mathrm{n}$ para $\mathrm{p}$, resultando em um fluxo de elétrons $\mathrm{e}$ buracos $^{59,65}$. Toda esta movimentação gera fótons em uma faixa estreita de comprimento de onda, ou seja, próxima de $470 \mathrm{~nm}$, concentrando-se dentro de um estreito espectro de emissão da luz visível e bastante próximo do pico de absorção máxima da canforoquinona (468nm).

Apoiado nessas características, MILLS ${ }^{75}$ (1995) propôs a utilização de aparelhos confeccionados com LEDs azuis para fotoativação de materiais resinosos, uma vez que estes aparelhos apresentam vantagens favoráveis para uso da comunidade odontológica. O fato de não necessitar sistema de filtro, não possuir sistema de ventilação, pois teoricamente não produzem calor, além do baixo consumo de energia, maior resistência a vibrações e/ou choques 
e apresenta vida útil mais longa, são benefícios importantes para o ponto de vista clínico-restarurador, sendo normalmente comparados com os aparelhos de luz halógena. Este aspecto é o elemento chave e responsável pelas realizações de diversas pesquisas relacionadas a tipos de fontes de luz e comportamento químico-mecânico

de matérias resinosos $4,7,13,36,38,50,55,59,65,69,74,79,94,100$.

Nesse sentido, mesmo que os aparelhos de LED apresentem baixa densidade de potência para alguns autores, a eficiência quanto ao comprimento de onda pode ser responsável por uma polimerização adequada das restaurações de resina composta ${ }^{4,13,105}$.

\subsubsection{Desgaste}

Embora existam todas essas vantagens e qualidades com a fonte de luz tipo LED, os resultados deste estudo não podem confirmar de forma absoluta todos os benefícios anteriormente destacados. É facilmente detectável, por meio da análise comparativa dos resultados obtidos no presente trabalho, que os grupos fotoativados com luz halógena em comparação aos fotoativados com aparelho de luz LED, quando empregada à mesma energia de ativação, apresentaram comportamentos distintos frente ao teste de escovação simulada.

Dentre os quatro grupos avaliados, os espécimes do grupo G2 fotoativados com fonte de luz halógena (VIP) e energia de $12 \mathrm{~J}\left(600 \mathrm{~mW} / \mathrm{cm}^{2} \mathrm{x}\right.$ 
20s), apresentaram o melhor comportamento mecânico e menor desgaste $(10,90 \pm 0,507 \mu \mathrm{m})$, após os procedimentos de abrasão (escovação simulada), com diferenças estatisticamente significantes em relação aos demais grupos. Os grupos G4 (LED $\left.600 \mathrm{~mW} / \mathrm{cm}^{2} \times 20 \mathrm{~s} ; \mathrm{E}: 12 \mathrm{~J}\right)$ e $\mathrm{G} 1\left(\mathrm{VIP} 300 \mathrm{~mW} / \mathrm{cm}^{2}\right.$ x 20s; E: $6 \mathrm{~J})$ apresentaram resultados intermediários de desgaste, 12,95 $\pm 0,510 \mu \mathrm{m}$ e $13,96 \pm 0,756 \mu \mathrm{m}$, respectivamente, com diferenças estatisticamente significantes em relação aos dois outros grupos. Em contrapartida, os espécimes do grupo G3 (LED $300 \mathrm{~mW} / \mathrm{cm}^{2}$ x 20s; E: 6J), apresentaram comportamento inferior frente ao teste de abrasão, com os maiores valores de desgaste $(34,63 \pm 1,931 \mu \mathrm{m})$, com diferença estatisticamente significante em comparação aos demais.

Uma correlação desses resultados em termos de valores absolutos, relacionados com a densidade de potência de ambas unidades fotoativadoras pode e deve ser comentada. Nesse sentido, constata-se que a luz halógena quando empregada com densidade de potência de $300 \mathrm{~mW} / \mathrm{cm}^{2}$ por $20 \mathrm{~s}$ e energia de ativação de 6 Joules (G1), proporcionou valores semelhantes de desgaste quando o aparelho de luz LED foi empregado com densidade de potência de $600 \mathrm{~mW} / \mathrm{cm}^{2}$ por $20 \mathrm{~s}$ e energia de ativação de 12 Joules (G4). Em função dos resultados obtidos, o aparelho de luz a base de LED precisou do dobro da energia de ativação para determinar comportamento semelhante da resina avaliada, frente ao teste de abrasão, quando comparado aos corpos-deprova fotoativados com luz halógena. Neste aspecto, a utilização clínica para a 
polimerização da resina avaliada (Z-250 3M/ESPE), com fonte de luz LED e densidade de potência de $300 \mathrm{~mW} / \mathrm{cm}^{2}$ por $20 \mathrm{~s}$, deve ser evitada.

Provavelmente, um dos fatores que explicaria as diferenças nos valores de desgaste, em função das diferentes fontes de luz (LH - LED) envolvidos neste trabalho, refere-se à inter-relação existente entre temperatura e grau de conversão ${ }^{55,105}$. É válido ressaltar que o aumento de temperatura proporcionado pela utilização da luz halógena (VIP/BISCO) em comparação ao aparelho de luz LED (Ultrablue IS / DMC equipamentos), nas duas densidades de potências empregadas (300 e $600 \mathrm{~mW} / \mathrm{cm}^{2}$ x 20s), na confecção dos corpos-de-prova, teve influência significativa no comportamento da resina composta avaliada. Em função dos resultados obtidos, o aumento de temperatura determinado pela luz halógena melhorou o grau de conversão das cadeias monoméricas da resina composta avaliada e, conseqüentemente, proporcionou melhor comportamento da mesma frente ao teste de abrasão.

Este aspecto é totalmente corroborado por KNEZEVIC et al. ${ }^{58}$ (2001), onde os autores compararam o grau de conversão das resinas compostas em relação ao aumento de temperatura quando da utilização dos aparelhos com fonte de luz halógena e LED. Os resultados mostraram que diferença proporcionada no grau de conversão (GC) das resinas, quando da utilização das unidades de luz halógena e LED, pode ser significante em virtude da diferença na produção de calor emitida por ambos aparelhos. O emprego de alta densidade de potência provocou, em algumas ocasiões, superfícies com 
aspecto vítrio das resinas. Os pesquisadores salientam que a irradiação com fonte de luz LED determinou aumento duas vezes menor de temperatura em comparação à luz halógena. Para eles, o aparelho LED mostrou-se uma alternativa promissora na fotopolimerização de materiais resinosos, principalmente em função do grau de conversão polimérica das resinas compostas.

Por outro lado, foi apontado anteriormente que com a colocação do filtro nos aparelhos de LH, $10 \%$ da densidade de potência da luz gerada diminui, abreviando desta forma a polimerização das restaurações em resina composta, mesmo com espessuras de $2 \mathrm{~mm}$. Dado que não é apoiado por vários autores na literatura ${ }^{35,49,69,71}$.

PIMENTEL et al. ${ }^{85}$ (2002), ao testarem a profundidade de polimerização de uma resina composta (Filtek Z-250), utilizando aparelhos com fonte de luz halógena (Optilux/Demetron) e fonte de luz LED (Ultrablue/DMC), nos tempos de 20s e 40s para polimerização de corpos-de-prova com 3mm de diâmetro e $6 \mathrm{~mm}$ de espessura, concluíram que o aparelho de LH apresentou melhor penetração de luz do que o LED, independente do tempo para a espessura de $6 \mathrm{~mm}$.

É nítida a importância que vem sida dada aos sistemas restauradores diretos, especialmente as resinas composta, em função de seu comportamento químico-mecânico no que diz respeito ao tamanho, número e distribuição das partículas de carga $^{78,98,99}$. Para LEINFELDER ${ }^{62}$ (1993), o pequeno grau de 
desgaste observado nas resinas compostas deve-se às modificações ocorridas em sua composição, que apresentam tamanho das partículas inorgânicas entre $100 \mu \mathrm{m}$ a $5 \mu \mathrm{m}$, resultando em diminuição de cerca de $50 \%$ do desgaste. Para o autor, a mudança da carga de quartzo para vidros moles tais como o bário, estrôncio e o silicato de alumínio de lítio, faz com que o impacto da mastigação seja melhor assimilado, o que não ocorria quando a carga era de quartzo. $\mathrm{O}$ pesquisador salienta que outra tendência importante foi o arredondamento das partículas de carga, o que diminuiu a concentração de estresse entre o material de carga e a matriz orgânica. Estas alterações levaram a diminuição no desgaste, reduzindo de $150 \mu \mathrm{m}$ para cerca de $8 \mu \mathrm{m}$ ao ano.

Em concordância com os dados obtidos por DICKINSON et al. ${ }^{26}(1990)$, o presente trabalho apresentou desgaste da resina composta correspondente a $10 \mu \mathrm{m}$ ou pouco mais ao ano. As causas para tal evolução seriam as ligações mais fortes entre a matriz orgânica e as partículas de carga, além da otimização do tamanho das partículas.

Apesar de não ter sido alvo de investigação deste trabalho, a velocidade de desgaste deve ser considerada. Este fato apresenta correlação clínica, como constatado por LEINFELDER; WILDER JUNIOR; TEIXEIRA ${ }^{63}$ (1986) que, por análise quantitativa de três anos, verificam taxa maior de desgaste nos períodos iniciais. Cerca da metade do desgaste do período inicial foi detectado nos primeiros seis meses, podendo se predizer o desgaste do material neste período. Apesar dessas investigações in vivo não especificarem o fator ou a 
associação de fatores de desgaste, parecem demonstrar que, independente do tipo de desgaste, o mesmo é maior em períodos iniciais, em semelhança a avaliações in vitro ${ }^{86}$.

Os resultados obtidos neste trabalho devem ser considerados nas condições determinadas na realização dos testes, para serem corretamente interpretados, mediante a influência de fatores externos no comportamento químico-mecânico das resinas compostas.

\subsubsection{Alteração da rugosidade superficial}

Outro aspecto que eleva a relevância deste estudo e, sobretudo, dos resultados obtidos é a rugosidade superficial, característica muito importante em qualquer tipo de material restaurador $^{104,112,113}$. Uma vez inserido na cavidade bucal, mesmo após o processo de acabamento e polimento, irregularidades se fazem invariavelmente presentes apesar da busca por uma lisura ideal.

Vários estudos buscam por maior lisura de acordo como os instrumentos aplicados $^{10,12,72}$. A utilização da tira de matriz proporciona a melhor e mais adequada lisura superficial $^{54}$. No entanto, na grande maioria das vezes, isto não é possível de se obter clinicamente, uma vez que as restaurações acabam por necessitar de procedimentos de acabamento e polimento ${ }^{24,54,111}$.

Esta preocupação com a obtenção de lisura superficial visa minimizar os efeitos de superfícies rugosas, como o acúmulo de placa, perda de brilho e 
manchamento. HACHIYA et al. $(1984)^{42}$ constataram que a precocidade no polimento poderia favorecer o manchamento. As superfícies obtidas pela matriz de poliéster apresentaram maior descoloração final, devido a maior presença de matriz orgânica, esta mais suscetível ao manchamento, quando comparadas clínica e laboratorialmente.

Deve-se considerar também a inter-relação que existe entre rugosidade superficial e acúmulo de placa dentária mostrada por WEITMAN; EAMES ${ }^{113}$ (1975). Pela análise em diferentes substratos, os autores constataram que mesmo as superfícies inicialmente mais lisas apresentavam, com o tempo, aumento da rugosidade superficial favorecendo, conseqüentemente, o acúmulo de placa. Portanto, a manutenção de uma superfície lisa por tempo maior seria o ideal e esta é uma das razões de investigação do comportamento superficial das restaurações. No entanto, com o tempo, o processo de desgaste parece propiciar modificações na textura superficial, o que foi proposto investigar neste trabalho.

De acordo com CARPINETTI ${ }^{19}$ (1996) e $\operatorname{RIOS}^{90}$ (2000), a rugosidade de uma superfície é basicamente quantificada por parâmetros relacionados à altura (amplitude) e largura (espaçamento) das irregularidades ou por uma combinação desses atributos. O parâmetro $\mathrm{Ra}$ (roughness average) retrata a média da rugosidade avaliada, considerando-se picos e vales registrados na medida de extensão. Esta medição é largamente utilizada neste tipo de 
análise $\mathrm{e}^{28}$ e foi adotada neste estudo para proporcionar melhores condições comparativas a outros trabalhos semelhantes ${ }^{46,86,87,111,112}$.

Por deslizamento da ponta apalpadora de diamante, as irregularidades de um determinado segmento da superfície são registradas, devendo ser representativas ao restante da superfície analisada. Ainda nesta análise, a escolha de uma escala padrão de filtragem, denominada cut-off, deve ser aplicada, evitando que as irregularidades e possíveis ondulações de superfície se sobreponham, interferindo na análise final da rugosidade superficial.

Seguindo este mesmo direcionamento, BATISTA ${ }^{10}$ (2003) destaca que uma série de elementos e parâmetros têm que ser levados em consideração, ao ser feita a leitura da rugosidade de uma superfície. Primeiramente, toda a linha da superfície submetida à medição sofre um processo de filtragem, a fim de corrigir-se as ondulações de grande magnitude apresentadas. Todo aparelho que realiza tal leitura (denominado rugosímetro ou perfilômetro) efetua automaticamente tal correção, através de um programa nele incorporado.

Para exemplificar, observe-se o esquema apresentado na figura 36 , no qual a letra A representa o perfil real numa linha da superfície, sem filtragem; a letra B representa as ondulações de grande magnitude, as quais serão eliminadas; e a letra $\mathrm{C}$ representa o perfil de rugosidade após a filtragem. 


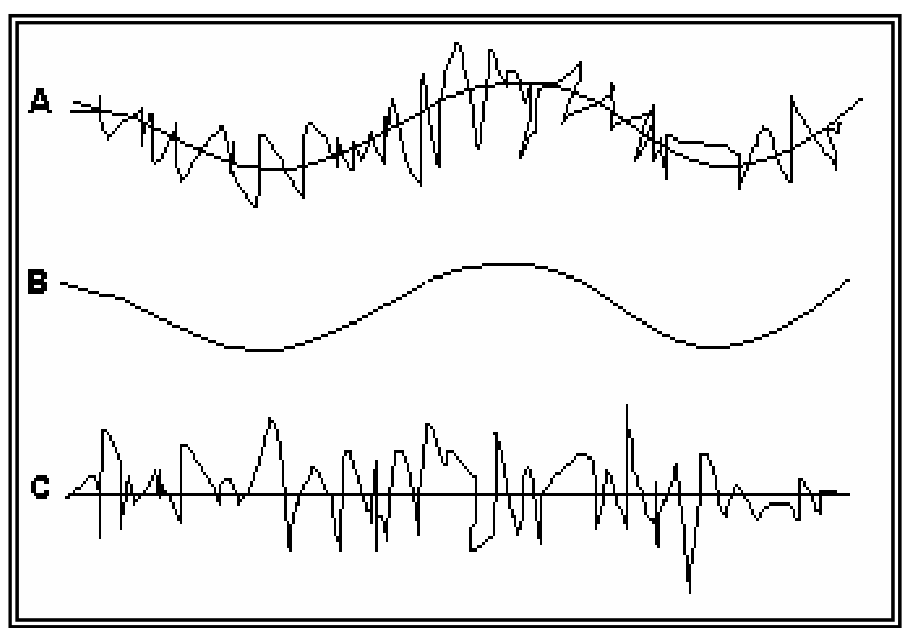

FIGURA 38 - Ilustração esquemática do processo de filtragem automática realizada pelo Rugosímetro em qualquer tipo de superfície

Comumente são realizados estudos comparando-se dados quantitativos e qualitativos de superfícies de materiais frente aos testes de resistência ao desgaste $23,39,46,86,87,89,90,112$. Os registros gráficos é outro recurso aplicado nesta diferenciação. HEATH, WILSON ${ }^{45}$ (1976) sugerem que a análise superficial de materiais heterogêneos, como as resinas compostas, deve ser determinada por meio da associação de testes quantitativos e qualitativos (MEV).

Por meio da análise das fotomicrografias obtidas neste estudo, pode-se observar que as superfícies de todos os grupos da resina composta avaliada apresentaram padrão de rugosidade diferente antes e após escovação simulada (Figuras 26, 27, 28, 29, 30, 31, 32, 33, 34 e 35). Independente da fonte de luz, tempo e da energia de ativação empregada, os grupos avaliados apresentaram o mesmo padrão de rugosidade superficial inicial, sem 
diferenças estatísticas (Tabela 7). Esta característica pode ser observada nos resultados iniciais de rugosidade superficial apresentados no gráfico da figura 22, na tabela 7 e nas figuras $26,27,28,30,32$ e 34 , onde é evidente a menor exposição das partículas inorgânicas nas superfícies dos corpos-de-prova previamente ao teste de abrasão.

Para vários autores ${ }^{1,16,25,29,30,43,83,87,88,97,112}$ a ocorrência de ranhuras, estrias e sulcos resultantes do procedimento de abrasão são comumente inevitáveis. As mesmas características foram observadas no presente estudo após a escovação simulada e podem ser confirmadas por meio da análise do gráfico da figura 23 e das fotomicrografias apresentadas nas figuras 26 e 27 , onde se pode comparar, em maior aumento, as diferenças entre o lado controle e lado escovado.

Semelhante aos resultados obtidos para o teste de desgaste, a alteração da rugosidade superficial apresentada pela resina composta Z-250 (3M/ESPE), após escovação simulada, foi influenciada de maneira significativa pela fonte de luz, densidade de potência e, conseqüentemente, da energia de ativação empregada na polimerização dos corpos-de-prova dos grupos avaliados. Apesar de não ter ocorrido correlação positiva entre desgaste e alteração de rugosidade superficial (teste de Pearson) para os grupos estudados, a variação da energia e fonte de luz empregadas na polimerização da resina proporcionou comportamento correlatos de alteração de rugosidade e desgaste. 
O grupo G2 (VIP $600 \mathrm{~mW} / \mathrm{cm}^{2} \times$ 20s) apresentou a menor variação de rugosidade superficial $(0,891 \pm 0,036 \mu \mathrm{m})$, após o teste de escovação simulada, em comparação aos demais grupos com diferenças estatisticamente significantes. Semelhante ao teste de desgaste, o grupo G3 (LED $300 \mathrm{~mW} / \mathrm{cm}^{2}$ x 20s) apresentou a maior variação de rugosidade superficial $(1,031 \pm 0,019$ $\mu \mathrm{m})$, com diferenças estatisticamente significantes em relação ao demais condições experimentais. Os grupos G1 (VIP $300 \mathrm{~mW} / \mathrm{cm}^{2}$ x 20s) e G4 (LED $600 \mathrm{~mW} / \mathrm{cm}^{2} \times 20 \mathrm{~s}$ ) apresentaram resultados intermediários de alteração de rugosidade superficial, $0,923 \pm 0,031 \mu \mathrm{m}$ e $0,918 \pm 0,032 \mu \mathrm{m}$, respectivamente.

O maior comprometimento superficial apresentado pelo grupo G3 pode ser verificado por meio da análise da fotomicrografia da figura 33 , onde se observa maior exposição das partículas de carga na superfície da resina composta e a presença nítida das estrias produzidas pelo contato das cerdas da escova dental. Em contrapartida, a análise das superfícies da resina composta dos outros grupos avaliados demonstra não haver diferenças perceptíveis em relação à exposição das partículas de carga e formação de estrias (Figuras 29, 31, 33 e 35).

Para KAPLAN et al. ${ }^{57}$ (1996) e O'BRIEN, YEE JUNIOR ${ }^{81}$ (1980), os valores de rugosidade superficial em torno de 10 a 15 micrometros não devem ser considerados clinicamente importantes, uma vez que o paciente não terá a capacidade de identificar a ausência de lisura superficial de qualquer tipo de restauração. Salientam que a língua tem a capacidade de detectar 
irregularidades superficiais somente acima de $20 \mu \mathrm{m}$. Apesar destas considerações, no presente trabalho o comportamento apresentado pela resina composta Z-250 (grupo G3), quando ativada com fonte de luz LED na densidade de potência de $300 \mathrm{~mW} / \mathrm{cm}^{2}$ por 20 segundos, sucinta dúvidas quanto ao comportamento clínico de uma restauração confeccionada com estes parâmetros.

Observa-se pelos resultados obtidos e discutidos neste experimento, que o comportamento mecânico (desgaste e rugosidade superficial) das restaurações de resina composta pode ser influenciado de forma positiva ou negativa, em função da energia de ativação e fonte de luz empregada na polimerização dos incrementos da resina composta. Provavelmente, a maior contribuição do presente trabalho está na análise comparativa do comportamento físico-mecânico de uma resina composta em função dos tipos de fontes de luz avaliados (halógena e LED), frente a um processo intrabucal de rotina (escovação), analisando-se seus efeitos sob condições padronizadas pré-estabelecidas, semelhantes às características clinicamente encontradas na cavidade oral. Não obstante, os resultados deste e qualquer tipo de trabalho in vitro só podem ser confirmados por meio de avaliações clínicas com longos períodos de observação na cavidade bucal. 
7 CONCLUSÕES 


\section{CONCLUSÕES}

Em função dos resultados obtidos no estudo proposto a hipótese nula apresentada deve ser recusada:

- A fonte de luz halógena determinou melhor comportamento mecânico para o compósito avaliado, em comparação à luz LED, quando empregada à mesma densidade de potência;

- Para as duas fontes de luz avaliadas a maior densidade de potência empregada $\left(600 \mathrm{~mW} / \mathrm{cm}^{2}\right)$ inferiu melhor comportamento fisico-mecânico, em termos de desgaste e rugosidade superficial, para a resina testada;

- Em termos gerais, o grupo fotoativado com lâmpada halógena com maior densidade de potência $\left(600 \mathrm{~mW} / \mathrm{cm}^{2}\right)$ determinou o melhor comportamento mecânico para a resina composta;

- O grupo fotoativado com lâmpada halógena com menor densidade de potência $\left(300 \mathrm{~mW} / \mathrm{cm}^{2}\right)$, quando comparado com o grupo LED $\left(600 \mathrm{~mW} / \mathrm{cm}^{2}\right)$, apresentaram comportamento fisico-mecânico semelhantes frente ao teste de escovação simulada. 
ANEXOS 
ANEXO 1 - Quadro das médias dos valores $(\mu \mathrm{m})$ de rugosidade superficial e desgaste registrados de cada corpo-de-prova do $\mathrm{G} 1\left(\mathrm{LH}=300 \mathrm{~mW} / \mathrm{cm}^{2} \times 20 \mathrm{~s}\right)$ e as diferenças obtidas após os testes de escovação simulada

\begin{tabular}{|c|c|c|c|c|}
\hline G1 / HT & R & RF & D & Desgaste \\
\hline 1 & 0,02 & 0,95 & 0,93 & 13,7 \\
\hline 2 & 0,04 & 0,96 & 0,92 & 13,4 \\
\hline 3 & 0,02 & 0,97 & 0,95 & 14,6 \\
\hline 4 & 0,02 & 0,97 & 0,95 & 13,2 \\
\hline 5 & 0,03 & 0,95 & 0,95 & 13,5 \\
\hline 6 & 0,03 & 0,94 & 0,91 & 13,6 \\
\hline 7 & 0,03 & 0,95 & 0,92 & 15,6 \\
\hline 8 & 0,03 & 0,95 & 0,92 & 14,7 \\
\hline 9 & 0,03 & 0,94 & 0,91 & 13,6 \\
\hline 10 & 0,05 & 0,96 & 0,91 & 13,7 \\
\hline
\end{tabular}

ANEXO 2 - Quadro das médias dos valores $(\mu \mathrm{m})$ de rugosidade superficial e desgaste registrados de cada corpo-de-prova do $\mathrm{G} 2\left(\mathrm{LH}=600 \mathrm{~mW} / \mathrm{cm}^{2} \times 20 \mathrm{~s}\right)$ e as diferenças obtidas após os testes de escovação simulada

\begin{tabular}{|c|c|c|c|c|}
\hline G2 / HS & R & RF & D & Desgaste \\
\hline 1 & 0,02 & 0,96 & 0,94 & 11,3 \\
\hline 2 & 0,03 & 0,95 & 0,92 & 11,5 \\
\hline 3 & 0,03 & 0,85 & 0,82 & 10,5 \\
\hline 4 & 0,02 & 0,87 & 0,85 & 10,6 \\
\hline 5 & 0,03 & 0,94 & 0,91 & 10,5 \\
\hline 6 & 0,02 & 0,86 & 0,84 & 10,4 \\
\hline 7 & 0,05 & 0,93 & 0,88 & 11,6 \\
\hline 8 & 0,04 & 0,95 & 0,91 & 10,4 \\
\hline 9 & 0,04 & 0,96 & 0,92 & 10,7 \\
\hline 10 & 0,04 & 0,96 & 0,92 & 11,5 \\
\hline
\end{tabular}


ANEXO 3 - Quadro das médias dos valores $(\mu \mathrm{m})$ de rugosidade superficial e desgaste registrados de cada corpo-de-prova do G3 (LED $300 \mathrm{~mW} / \mathrm{cm}^{2} \times 20 \mathrm{~s}$ ) e as diferenças obtidas após os testes de escovação simulada

\begin{tabular}{|c|c|c|c|c|}
\hline G3 / LT & RI & RF & D & Desgaste \\
\hline 1 & 0,02 & 1,07 & 1,05 & 33,3 \\
\hline 2 & 0,02 & 1,06 & 1,04 & 35,2 \\
\hline 3 & 0,04 & 1,07 & 1,03 & 32,6 \\
\hline 4 & 0,03 & 1,06 & 1,03 & 34,9 \\
\hline 5 & 0,04 & 1,05 & 1,01 & 34,2 \\
\hline 6 & 0,04 & 1,06 & 1,02 & 36,6 \\
\hline 7 & 0,05 & 1,07 & 1,02 & 38,6 \\
\hline 8 & 0,03 & 1,07 & 1,04 & 32,6 \\
\hline 9 & 0,05 & 1,07 & 1,02 & 33,8 \\
\hline 10 & 0,05 & 1,07 & 1,02 & 34,2 \\
\hline
\end{tabular}

ANEXO 4 - Quadro das médias dos valores $(\mu \mathrm{m})$ de rugosidade superficial e desgaste registrados de cada corpo-de-prova do G4 (LED $600 \mathrm{~mW} / \mathrm{cm}^{2} \times 20 \mathrm{~s}$ ) e as diferenças obtidas após os testes de escovação simulada

\begin{tabular}{|c|c|c|c|c|}
\hline G4 / LS & RI & RF & D & Desgaste \\
\hline 1 & 0,04 & 0,96 & 0,92 & 13,4 \\
\hline 2 & 0,03 & 0,94 & 0,91 & 13,5 \\
\hline 3 & 0,03 & 0,95 & 0,92 & 12,6 \\
\hline 4 & 0,05 & 0,97 & 0,92 & 12,7 \\
\hline 5 & 0,03 & 0,94 & 0,91 & 12,4 \\
\hline 6 & 0,04 & 0,96 & 0,92 & 12,6 \\
\hline 7 & 0,03 & 0,93 & 0,93 & 13,6 \\
\hline 8 & 0,03 & 0,95 & 0,92 & 13,7 \\
\hline 9 & 0,04 & 0,96 & 0,92 & 12,7 \\
\hline 10 & 0,05 & 0,96 & 0,91 & 12,4 \\
\hline
\end{tabular}


REFERÊNCIAS BIBLIOGRÁFICAS 


\section{REFERÊNCIAS BIBLIOGRÁFICAS*}

1) AKER, J.R. New composite resins: comparison of their resistence to toothbrush abrasion and characteristics of abraded surfaces. J Amer Dent Ass,v.105, n.10, p.633-5, Oct 1982.

2) AMERICAN DENTAL ASSOCIATION. Council on dental materials, instruments and equipment. Obstacles to the development of a standard for posterior composite resins. J Amer Dent Ass, v.118, n.5, p.649-51, May 1989.

3) AMERICAN DENTAL ASSOCIATION. Council on Dental Materials and Devices. Specification n.27 for direct filling resins. J Amer Dent Ass, v.94, n.6, p.1191-5, June 1977.

4) ASHMORE, H.; VAN ABBE, N.J.; WILSON, S.J. The measurement in vitro of dentine abrasion by toothpaste. Brit Dent J, v.133, n.2, p.60-6, July 1972.

5) ASMUSSEN, E. Restorative resins: hardness and strength vs. quantity of remaining double bonds. Scand J Dent Res., v.90, n.6, p.1627-8, Nov 1998

6) ASSOCIAÇÃO BRASILEIRA DE NORMAS TÉCNICAS. Rugosidades das superfícies: Procedimentos. NBR 6405,1988.

7) AZEVEDO , L.R.; CATRAMBY, M.F.; FRANCO; E.B. Interrelation of light intensity, depth of cure and curing units. J Dent Res, v.76, Special Issue, p.324, Mar.1997. / Abstract n. 2481 /

\footnotetext{
*Normas recomendadas para uso no âmbito da Universidade de São Paulo, com base no documento "Referências Bibliográficas: exemplos", emanados do Conselho Supervisor do Sistema Integrado de Bibliotecas da USP, em reunião de 20 de setembro de 1990.
} 
8) BARBAKOW, F.; LUTZ, F.; INFELD, T. Relative dentin abrasion by dentifrices and prophylaxis pastes: implications for clinicians, manufacturers, and patients. Quintessence Int, v.18, n.1, p.29-34, Jan 1987.

9) BASTOS, J.R.M. et al. Contribuição à posologia de dentifrícios pelo cirurgão-dentista no Brasil. Rev Gaúcha Odont, v.33, n.3, p.202-5, jul./set. 1995.

10) BATISTA, W.V.B. Avaliação da eficiência do polimento efetuado em superfícies de vidro e de amálgama, por pontas de "borracha abrasiva" ou pastas para polimento, em relação à perda de massa e à rugosidade. Bauru, 2003. 122p. Dissertação (Mestrado) - Faculdade de Odontologia de Bauru, Universidade de São Paulo.

11) BISHOP, K. et al Wear now? An update on the etiology of tooth wear. Quintessence Int., v.28 n.5, p.305-12, May 1997.

12) BOLANHO, A. et al. Estudo In vitro da rugosidade superficial de resinas para dentes posteriores submetidas a diversos tratamento de superfície. J Bras Dent Est, v.2, n.5, p.51-7, jan./mar. 2003.

13) BOSQUIROLI, V. Avaliação da resistência à tração de uma resina composta fotopolimerizável em função de diferentes fontes de luz e de tempos de ativação. Bauru, 2003, 73p. Dissertação (Mestrado) Faculdade de Odontologia de Bauru, Universidade de São Paulo. 
14) BOWEN, R.L. Dental filling material comprising vinil silane treated fused sílica and a bider consisting and glycidyl acrylate. US Patent 3.066.1121962.

15) BOWEN, R.L. Properties of a sílica-reinforced polymer for dental restorations. J Amer Dent Ass, v. 68, n.1, p.57-64, Jan 1963.

16) BUCHALLA, W.; ATTIN, T.; HELLWIG, E. Brushing abrasion of luting cements under neutral and acidic conditions. Oper Dent, v.25, p.482-7, 2000.

17) BURGESS, J.O. et al. Light curing an update. Compendium, v.23, n.10, p.889-906, Jan 2002.

18) BURTSCHER, P.; RHEINBERGER, V. Efficiency of LED lights in comparison to halogen lamps. J Dent Res, v.81, p. A-486, Mar. 2002. Special Issue. / Abstract 3975 /

19) CARPINETTI, L.C.R. et al. Rugosidade superficial: conceitos e princípios básicos de medição. São Carlos, Seção de Publicações da EESC-USP, 1996.

20) CARVALHO, M.C.F.S. Influência da energia utilizada na fotoativação de resinas compostas na dureza superficial e no número relativo de radicais livres. Bauru, 2002. 57p. Tese (Doutorado) - Faculdade de Odontologia de Bauru, Universisdade de São Paulo.

21) CARVALHO, R.M. de. Adesivos dentinários. Fundamentos para aplicação clínica. Rev Dent Rest, v.1, n.2, p.62-96, abr./jun.1998. 
22) CAUGHMAN, W.F.; RUEGGEBERG, F.A.; CURTIS JUNIOR, J.W. Clinical guideliness for photocuring restorative resins. J Amer Dent Ass, v.126, n.9, p.1280-4, Sept 1995.

23) CORRER SOBRINHO, L. et al. Influência da escovação na rugosidade de superfície de materiais restauradores estéticos. RPG Rev Pós Grad, v.4, n.1, p.47-55, 2001.

24) DANSER, M.M. et al. Evaluation of the incidence of gingival abrasion as a result of toothbrushing. J Clin Periodont, v.25, n.9, p701-6, Sept 1998.

25) DE GEE, A.J.; HARKEL-HAGENAAR, H.C.,; DAVIDSON, C.L. Structural and physical factors affecting the brush wear of dental composites. J Dent, v.13, n.1, p.60-70, Mar 1985.

26) DICKINSON, G.L. et al. Effect of surface penetratig sealant on wear rate of posterior composite resins. J Amer Dent Ass, v.121, n.4, p.251-255, Jun 1990.

27) DUNN, W.J.; VUSH, A. C. A comparisson of four modes of evaluating depth of light-activated composites. J Amer dent Ass., v.133, n.3, p.335-41, Mar. 2002.

28) EHRNFORD, L. et al. An abrasion test for composite resins. J Dent Res, v.59, n.4, p.716-20, Apr 1980.

29) EHRNFORD, L. Surface microstructure of composite resins after toothbrush-dentifrice abrasion. Acta Odont Scand, v.41, n.4, p.337-46, Aug 1983. 
30) FACQ, J.M.; VOLPE, A.R. In vivo actual abrasiveness of three dentifrices against acrylic surfaces of veneer crowns. J Amer Dent Ass, v.80, n.2, p.317-23, Feb 1970.

31) FERRACANE, J.L. Elution of leachable components from composites. J Oral Rehabil, v.21, n.4, p.441-52, July 1994.

32) FAY, R.M.; LU, H; PWERS, J.M. Mechanical properties of composite cured with LED and QTH curing light. J Dent Res, v.81, p. A-85, Mar.2002. / Abstract n. 0484 /

33) FERRAREZI, G.A.O.; CEFALY, D.F.G.; NAVARRO, M.F.L. Microdureza de materiais resinosos polimerizados com luz halógena e luz emitida por diodo (LED). Pesq Odontol Bras, v.17, p.94, 2003. Suplemento 2. I Resumo Ic118 /

34) FERREIRA, F.V. et al. Avaliação da rugosidade superficial na escovação de resinas compostas. Bauru, Faculdade de Odontologia de Bauru. 1998. (CNPq 522568/95-5)

35) FIROOZMAND, L.M.; ARAUJO, R.M.; BALDUCCI, I. Influencia de fotopolimerizadores de luz hológena versus LED azul na dureza de resina composta. Pesq Odontol Bras, v.17, p.47, 2003. Suplemento 2. I Resumo la126 /

36) FRANCO, E.B.; LOPES, L.G. Conceitos atuais na polimerização de sistemas restauradores resinosos BioOdonto, v.1, n.2, p.1-59, mar./abr. 2003. 
37) FRANCO, E.B.; NAVARRO, M.F.L. Avaliação do comportamento do sistema de polimerização por luz emitida por diodo, LED, em comparação ao sistema de luz halógena. Bauru, FOB-USP, 2002.

38) FRIEDMAN, M.J. New light curing options for composite resin restorations. Compendium, v.20, n.2, p.122-35, Feb. 1999.

39) GARCIA, F.C.P. Avaliação comparativa das resinas compostas fluidas em relação à resistência à abrasão (escovação simulada). Bauru, 2001. 142p. Dissertação (Mestrado) - Faculdade de Odontologia de Bauru, Universidade de São Paulo.

40) GIL, E.J. et al. Comparison of the abrasive wear resistance between amalgams, hybrid composite restorations. Quintessence Int, v.49, n.6, p.337-42, Dec 1999

41) GRABENSTETTER, R.J. et al. The measurement of the abrasion of human teeth by dentifrice abrasives: a test utilizing radioactive teeth. $\mathbf{J}$ Dent Res, v.37,n.6, p.1060 - 8, Nov./Dec.1958.

42) HACHIYA, $Y$ et al. Relation of finish to discoloration of composite resins. J Prosth Dent, v.52, n.6, p.811-4, Dec 1984.

43) HARRINGTON, E. et al. Toothbrush-Dentifrice abrasion. Brit Dent Res, v.153, n.4, p.135-8, Aug 1982.

44) HARTE, D.B.; MANLY, R.S. Four variables affecting magnitude of dentifrice abrasiveness. J Dent Res,v.55, n.3, p.322-7, May/Jun. 1976. 
45) HEATH, J.R.; WILSON, H.J. Abrasion of restorative materials by toothpaste. J. Oral Rehabil, v.3, n.2. p.121-38, Apr 1976.

46) HONÓRIO, H.M. Avaliação do desgaste de diferentes métodos de profilaxia sobre o esmalte bovino hígido e desmineralizado. Bauru, 2003. 70p. Dissertação (Mestrado) - Faculdade de Odontologia de Bauru, Universidade de São Paulo.

47) INTERNATIONAL ORGANIZATION FOR STANDIZATION. Technical specification 14569-1. Dental materials-guidance on testing of wear resistence-Part 1: wear by tooth brushing. Switzerland, ISO, 1999.

48) JACKSON, R.D.; MORGAN, M. The new posterior resins and a simplified placement technique. J Amer Dent Ass, v.131, n.3, p. 375-83, Mar 2000.

49) JANA, B.C.; SANTOS, M. CORRÊA. Influência da fotoativação por LED e luz halógena na resistência flexural de várias resinas compostas. Pesq Odontol Bras, v.16, p.106, 202. Suplemento / Resumo Ic 132 /

50) JANDT, K.D. et al. Depth of cure and compressive strength of dental compositecured with blue light emitting diodes (LEDs). Dent Mat, v.16,n.1, p.41-7, Jan 2000.

51) JONES, P.A.; FISHER, S.E.; WILSON, H.J. Abrasivity of dentifrice on anterior restorative materials. Brit. Dent. J, v.158, n.3, p.130-3, Feb. 1985. 
52) JONES, P.A.; JONES, D.W.; WILSON, H.J. A simple abrasion test for composites. J Dent, v.1, n.1, p. 28-34, Oct.1972.

53) JORGENSEN, K.D. In vitro wear tests on macro-filled composite restorative materials. Aust Dent J, v.27, n.3, p.153-8, June 1982.

54) JORGENSEN, K.D.; ASMUSSEN, E. Occlusal abrasion of a composite restorative resin with ultra-fine filler-an initial study. Quintessence Int, v.9, n.6, p.73-8, June 1978.

55) KALIX, A.P. et al. Avaliação in vitro dos efeitos de duas fontes de luz no grua de conversão monomérica de um compósito de alta densidade. Pesq Odontol Bras., v.17, p.137, 2003. Suplemento 2. / Resumo Pa235. I

56) KALACHANDRA, S; TURNER, D.T. Water sorption of polymethacrylate networks: Bis-GMA/TEGDM copolymers. J Biomed Mat Res, v.21, n.2, p. 329-38, Mar 1987.

57) KAPLAN, B.A. et al. The effect of three polishing systems on the surface roughness of the hybrid composites: A profilometric and scanning electron microscopy study. J Prosthet Dent, v.76, n.1, p.34-8, July 1996.

58) KNEZEVIC, A. et al. Degree of conversion and temperature reise during polymerization of composite resin samples with blue diodes. J Oral Rehabil, v.28, n.6, p.586-91, June 2001. 
59) KURACHI, C. et al. Hardness evaluation of a dental composite polymerized with experimental LED-based devices. Dent Mat, v. 17, n.4, p.309-15, July 2001.

60) KREJEI, I.; LUTZ, F.; ZELDER, C. Effects of contact área size on enamel and composite wear. J Dent Res, v.17, n.7, p.1413-6, July 1992.

61) LAMBRECHTS, M. et al. Quantitative in vivo wear of human enamel. J Dent Res, v.68, n.12, p.1752-4, Dec.1989.

62) LEINFELDER, K.F. Posterior composite state-of-the-art clinical application. Dent Clin N Amer, v.37, n.2, p.411-8, June 1993.

63) LEINFELDER, K.F.; WILDER JUNIOR, A.D.; TEIXEIRA, L.C. Wear rates of posterior composite resins. J Amer Dent Ass, v.112, n.6, p.829-33, June 1986.

64) LEINFELDER, K.F. New development in resin restorative system. J Amer Dent Ass, v.128, n.5, p.573-84, May 1997.

65) LEINFELDER, K.F. What intensity is best in light curing? J Amer Dent Ass, v.130, n.3, p.534-38, Apr 1999.

66) LEITÃO, J.; HEGD AHL,T. On the mesuring of roughness. Acta Odont Scand, v.39, n.6, p.379-84, June 1981.

67) LINDQUIST, B.; EMILSON, C.G. Distribution and prevalence of mutans streptuococci in the human dentition. J Dent Res, v.69, n.5, p.1160-6, May 1990. 
68) MACCHI, R.L.; BIEGELIS, A.A. RIBAS, L.M.T. Wear in three different composite resins. Acta Odont Latinoamer, v.1, n.1, p.37-40, July 1984.

69) MARAIS, J.T. et al. Depth of cure of light-cured composite resin with lightcuring units of different intensity. J Dent Ass S Afr, v. 52, n.6, p.403-7, June 1997.

70) MATSUMURA, H.; LEINFENDER, K.L. Localized three budy wear of six types of composite resin veneering materials. J Prosthet Dent, v.10, n.4, p.207 -13, July 1993.

71) MEIRA , J.B.C.; CARDOSO, P.E.C. Avaliação da dureza Knoop e da resistência ao desgaste de resina composta em função da cor e da fonte ativadora. RPG - Rev Pós-Grad, v.3, n.4, p.324-6, out./dez. 1996.

72) MENDOÇA, C. et al. Surface roughness evaluation of flowable composite resins before and after brushing. J Dent Res, v.81, p.339, 2002. Special Issue. / Abstract 2702 /

73) MILLER, W.D. Experiments and observations on the wasting of tooth tissue variously designated as erosion, abrasion, chemical abrasion, denudation, etc. Dent Cosmos, v.49, n.1, p.1-23, Jan 1907.

74) MILLS, R.W.; JANDT, K.D.; ASHWORTH, S.H. Dental composite depth of cure with halogen and blue light emitting diode technology. Brit Dent J, v.186, n.8, p.388-91, Apr.1999. 
75) MILLS, R.W. Blue light emitting diodes: another method of light curing. Brit Dent J, v.178, n.5. p.169, Mar 1995.

76) MITCHEM, J.C.; GRONAS, D.G. In vivo evaluation of the wear of restorative resin. J Amer Dent Ass, v.104, n.3, p.333-5, Mar.1982.

77) MOMOI, Y. et al. Abrasion and color stability of tooth-colered restoratives. J Dent Res, v.79, p.280, 2000. Special issue. /Abstract 1089. /

78) MONDELLI , R.F.L. Uso clinico das resinas compostas em dentes posteriores. Maxi-odonto: Dentística, v.1, n.3,p.1-58, maio/jun. 1995.

79) NAGEL, R. Operation and diagnostic features of the VIP light. Compendium, v.20, n.25, p.55-9, Jan 1999.

80) ONO, R. Estudo in vitro da rugosidade superficial produzida pela escovação na superfície de resinas composta. Piracicaba, 1997. 153p. Tese (Doutorado) - Faculdade de Odontologia de Piracicaba, Universidade Estadual de Campinas.

81) O'BRIEN , W.J.; YEE JUNIOR, J. Microstructure of posterior restorations of composite resin after clinical wear. Oper Dent, v.5, p.90-4, July.1980.

82) PANZERI, H. et al. Avaliação de dentifrícios III- desgaste provocado por escovação “in vitro." Odont Mod, v.6, n.2, p.26-32, Feb 1979.

83) PEREIRA, O. L. Desgaste das cerdas das escovas. Rev Gaúcha Odont, v.40, n.4, p.267-9, jul./ago. 1992. 
84) PEUTZFELDT, A. Correlation between recordings obtained with a lightintensity tester and degree of conversion of a light-curing resin. Scand J Dent Res, v.102, n.1, p.73-5, Feb 1994.

85) PIMENTEL, K. L. et al. LED versus luz halógena: efeito na espessura de polimerização da resina composta. Pesq Odontol Bras., v.16, p.77, 2002 / Resumo n.lb129. I

86) POWELL, J.M.; PHILLIPS, R.W.; NORMAN, R.D. In vitro wear reponse of composite resin, amalgam, and enamel. J Dent Res, v.54, n.6, p.118395, Nov./Dec.1975.

87) PRAKKI, A. Resistência ao desgaste de cimentos resinosos submetidos à ciclagem de pH e escovação simulada. Bauru, 2003. Dissertação (Mestrado) - Faculdade de Odontologia de Bauru, Universidade de São Paulo.

88) RATANAPRIDAKUL, $K$. et al. Effect of finishing on the in vivo wear of a posterior composite resin. J Amer Dent Ass, v.118, n. 6, p.333-5, June 1989.

89) RICHMOND, R.; MACFARLANE, J.F.; McCORD, J.F. Na evaluation of the surface changes in PMMA biomaterial formulations as a result of toothbrush / dentifrice abrasion. Dent Mat, v.20, n.2, p.124-32, Feb 2004.

90) RIOS, D. Avaliação do desgaste e rugosidade superficial de materiais utilizados para selante, submetidos à escovação com dois 
diferentes dentifrícios. Bauru, 2001. 149p. Dissertação (Mestrado) Faculdade de Odontologia de Bauru, Universidade de São Paulo.

91) RUEGGEBERG, F.A. Contemporary issues in photocuring. Compendium, v.20, p. 4-15, Nov.1999. Suplemento 25.

92) RUYTER, I.E; ØYSEAD, H. Conversion in different depths of ultravilolet and visible light activated composite materials. Acta Odont Scand, v.40, n.3, p.179-92, May 1982.

93) RUYTER, I.E; ØYSEAD, H. Composites for use in posterior teeth: composition and conversion. J Biomed Mat Res, v.21, n.1, p.11-23, Jan. 1987.

94) SANTOS, M.J.; SILVA e SOUZA. M.H.; MONDELLI, R.F.L. Novos conceitos relacionados à fotopolimerização das resinas compostas. J Bras Dent Est, v.1, n.1, p.14-21, jan./mar. 2002.

95) SCHMIDLIN, P.R.; SENER, B.; LUTZ, F. Cleaning and polishing efficacy of abrasive-bristle brushes and a prophylaxis paste on resin composite material in vitro. Quintessence Int, v.33, n.9, p. 691-9, Mar 2002

96) SHORTALL, A.; HARRINGTON, E. Guidelines for the selection, use and maintenance of visible light activation units. Brit Dent J, v.181, n.10, p. 383- 7, Nov.1996.

97) SEXSON, J.C.; PHILLIPS, R.W. Studies on the effect of abrasives on acrylic resins. J Prosthet Dent., v.1, n.4, p.454 -71, July 1951. 
98) SILVA E SOUZA JUNIOR, M.H. da. Procedimentos restauradores estéticos em resina e porcelana para dentes posteriores. Rev Dent. Rest, v.1, n.1, jan./mar.1998.

99) SILVA E SOUZA JUNIOR, M.H. da.; CARVALHO, R. M.; MONDELLI, R.F.L. Restaurações estéticas. Fundamentos para aplicação clínica. Restaurações com resina compostas. São Paulo, Ed. Santos, 2000.

100) STAHL, F. et al. Light-emitting diode (LED) polymerisation of dental composite: Flexural properties and polymerization potencial. Biomaterials, v.21, n.13, p.1379-85, July 2000.

101) STOOKEY, G.K.; MULHER, J.C. Laboratory studies concerning the enamel and dentin abrasion properties of common dentifrice polishing agents. J Dent Res, v.47,n.4, p.524-32, July/Aug.1968.

102) SUZUKI, S.; LEINFELDER, K.F.; SHINKAI, K. Wear resistance of resin cements. Amer J Dent, v.8, n.2, p.83-7, 1995.

103) TSAI, P.C.L.; MEYERS, I.A.; WALSH, L.J. Depth of cure and surface microhardness of composite resin cured with blue LED curing lights. Dent Mat., v.20, n.1, p.364-69, June 2004.

104) TURSSI, C.P. Micromorfologia superficial de materiais estéticos submetidos a diferentes processos de degradação. Piracicaba, 2001. Dissertação (Mestrado) Faculdade de Odontologia de Piracicaba - Universidade Estadual de Campinas. 
105) UHI, A.; MILLS, R.W; JANDT, K.D. Polymerization and light-induced heat of dental composites cured with LED and halogen technology. Biomaterials, v.24, n.10, p.1809 - 20, May 2003.

106) VAN DIJKEN, J.W.V.; RUYTER, E.I. Surface characteristics of posterior composites after polishing and toothbrushing. A scanning electron microscopy study. Acta Odont. Scand, v.45,n.5, p.337-46, Aug 1987.

107) VAN DIJKEN, J.W.V.; STADIGH, J.; MEURMAN, J.H. Appearance of finished and unfinished composite surface after toothbrushing. A scanning electron microscopy study. Acta Odont Scand, v.41, n.6, p.377-83, July 1983.

108) VAN GROENINGEN, G. In vivo - abrasion of composites: a quantitative investigation. Quintessence Int, v.12,n.10, p.1101-7, Oct. 1981.

109) VELLASCO, K. et al. Análise comparativa da rugosidade superficial de resinas compostas ativadas por LED e luz halógena Pesq Odont bras, v.17, p.46, 2003 Suplemento 2. / Resumo n.la118. /

110) VIEIRA, D.F. Studies on hardeness and abrasion resistence of acrylic resins. Indianópolis, 1960.102p. Dissertação (mestrado) Indiana University School of Dentistry.

111) WARD, M. T.; TATE, W.H.; POWERS, J.M. Surface roughness of opalescent porcelains after polishiing. Oper Dent, v.20, n.3, p.10610, May/June 1995. 
112) WANG, L. Avaliação comparativa da resistência à abrasão de resinas compostas condensáveis, submetidas à escovação simulada, através da alteração de massa e da rugosidade superficial. Bauru, 2001. p.110 Dissertação (Mestrado) - Faculdade de Odontologia de Bauru, Universidade de São Paulo.

113) WEITMAN, R.T.; EAMES, W.B. Plaque accumulation on composite surfaces after various finishing procedures. J Amer Dent Ass, v.91, n.1, p.101-6, July 1975.

114) WHATATE. L; PORTER, K.H.; DOSCH, R.O. Successuful photocuring: don't restore without it. Oper Dent, v.24, n.2, p.109-14, Mar./Apr.1999.

115) WILLEMS, G. et al. Three-year follow-up of five posterior composite: SEM study differential wear. J Dent, v.21, n.3, p.79 -86, June 1993.

116) WU, W.; McKINNEY, J.E. Influence of chemicals on wear of dental composites. J Dent Res, v.61,n.10, p.1180-3, Oct. 1982. 
ABSTRACT 


\section{ABSTRACT}

\section{EVALUATION OF WEAR AND SUPERFICIAL ROUGHNESS OF A COMPOSED RESIN, AFTER SIMULATED BRUSHING, IN FUNCTION OF DIFFERENT ENERGIES AND SOURCES OF LIGHT USED IN THE POLYMERIZATION}

An in vitro study was conducted for evaluation of wear and surface roughness of the composite resin Filtek $^{\mathrm{TM}}$ Z-250 (3M/ESPE) after simulated toothbrushing, according to different light energies and sources employed for curing. Two light sources were employed, namely halogen (QTH) (VIP/BISCO) and LED (Ultrablue IS / DMC Equipments). A stainless steel template was used to obtain forty specimens $(15 \times 5 \mathrm{~mm})$ divided into 4 groups: $\mathrm{G} 1=\mathrm{QTH}$ $300 \mathrm{~mW} / \mathrm{cm}^{2} \times 20 \mathrm{~s} ; \mathrm{G} 2=\mathrm{QTH} 600 \mathrm{~mW} / \mathrm{cm}^{2} \times 20 \mathrm{~s} ; \mathrm{G} 3=$ LED $300 \mathrm{~mW} / \mathrm{cm}^{2} \times 20 \mathrm{~s}$ and G4 = LED $600 \mathrm{~mW} / \mathrm{cm}^{2} \times 20$ s. Half of the each specimens was protected, and the other half was submitted to 200,000 brushstrokes using toothbrushes (Kolynos) and dentifrice (Colgate) diluted in deionized water. Wear was established after accomplishment of 5 readings for each specimen. The roughness meter was employed for observation of differences in the actual profile between the two surfaces. The alteration in surface roughness (Ra) was calculated by the difference between the mean of the five initial readings (before toothbrushing) and five final readings (after toothbrushing). The results were submitted to a two-way analysis of variance and to the Tukey test $(p<0.05)$. The wear rates observed were: G1: $13.96 \pm 0.756 \mu \mathrm{m}(\mathrm{B}) ; \mathrm{G} 2: 10.90 \pm 0.507 \mu \mathrm{m}(\mathrm{A})$; G3: $34.63 \pm 1.931 \mu \mathrm{m}(\mathrm{C})$ and $\mathrm{G} 4: 12.95 \pm 0.510 \mu \mathrm{m}(\mathrm{B})$. The differences in surface 
roughness (Ra) were: $\mathrm{G} 1$ : $0.923 \pm 0.031 \mu \mathrm{m}(\mathrm{B})$; $\mathrm{G} 2$ : $0.891 \pm 0.036 \mu \mathrm{m}(\mathrm{A})$; G3: $1.031 \pm 0 ; 019 \mu \mathrm{m}(\mathrm{C})$ and $\mathrm{G} 4: 0.918 \pm 0.032 \mu \mathrm{m}(\mathrm{B})$. In general, the QTH curing unit provided better physicomechanical performance of the composite resin compared to the LED curing unit with the same activation energy. 